\title{
合成無機イオン交換体の分析化学への応用 II
}

——酸性塩,ヘテロポリ酸塩扔よび不溶性フェロシアン化物——

\section{阿 部 光 雄*}

-

\section{1 は じめ に}

すでに Iでは“水酸化物および念水酸化物”の分析化 学への応用について述べた ${ }^{\mathrm{R} 14)}$. 本稿では“酸性塩,ヘテ ロポリ酸類および不溶性フェロシアン化物”について述 べる．その他の無機イオン交換体としてゼオライトを含 む合成アルミノケイ酸塩, 合成アパタイト, アルカリ金 属硫酸塩，金属硫化物などがある．前二者では分析化学 への応用は限られていることおよび後二者ではとの吸着 がイオン交換によるかどうか疑問があるので割愛した。

\section{2 酸 性 塩}

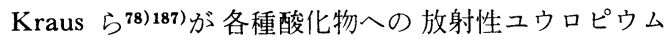
(III) の吸着を検討した際に，偶然にもリン酸を含んだ 市販酸化ジルコニウムがすぐれた吸着性を示すことがわ かった、これからリン酸ジルコニウムが有用なイオン交 換体であることが見いだされ，合成無機イオン交換体の 研究の端緒となったと思われる. その後数多くの酸性塩 の合成が試みられ，それらのイオン交換性や分析化学へ の忘用が研究された.

これら難溶性の酸性塩の調製は金属（周期表の IV たは V 族）の塩にこれよりも酸性の酸化物を結合させ ることによって得られる. 多くは陽イオン交換性を示 し, 交換容量も比較的大きく, 耐熱性や耐放射線性をも っている. 現在までに報告されている酸性塩の組み合わ せを Table I に示した. 概して酸性度の高い金属とそ れよりも高い酸化物からなる酸性塩は酸性度が高く, 低 い $\mathrm{pH}$ からも吸着されるが，その逆では低い $\mathrm{pH}$ での吸 着性は小さくなる.

これらの酸性塩のうち 4 価金属, 特にリン酸ジルニ ウムの研究が最も多いが最近では他の金属の酸性塩も盛 んに行なわれるようになった。

* 東京工業大学理学部化学科：東京都目黒区大岡山 2-12-1
Table I The possible elements to make the insoluble acid salt of polybasic metal

\begin{tabular}{lll}
\hline \multicolumn{1}{c}{ IV } & \multicolumn{1}{c}{ V } & VI \\
\hline $\mathrm{Si}$ & $\mathrm{P}$ & \\
$\mathrm{Ge} \mathrm{Ti}$ & As V & $\mathrm{Se} \mathrm{Gr}$ \\
$\mathrm{Sn} \mathrm{Zr}$ & $\mathrm{Sb} \mathrm{Nb}$ & $\mathrm{Te} \mathrm{Mo}$ \\
$\mathrm{Pb} \mathrm{Hf}$ & $\mathrm{Bi} \mathrm{Ta}$ & $\mathrm{W}$ \\
\hline
\end{tabular}

\subsection{4 価金属の酸性塩}

4 価金属の可溶性塩にリン酸, 七酸, タングステン酸 やモリブデン酸などを加え，適当な $\mathrm{pH}$ にすると無定形 または微細結唱の酸性塩が生成する.リン酸や七酸のよ うに，それ自身が加水分解しないようなものは濃厚な酸 溶液かフッ化水素酸のように溶解性の強い酸といっしょ に還流すると $\mathrm{M}^{\mathrm{IV}}\left(\mathrm{HXV}^{\mathrm{V}} \mathrm{O}_{4}\right)_{2} \cdot y \mathrm{H}_{\mathbf{2}} \mathrm{O}$ の一定組成の結 晶性酸性塩が得られる。これらは層間距離は異なるがい ずれも層状構造をもっている.

これら結晶性のものはあとで述べるようにイオンふる い効果や相転移などで共通している19) 22) 25) 87)。 また無 定形や微結晶のものは分析化学的にはより重要であり, 分析化学的基礎的研究でも未解決な問題が多い.

この 4 価金属の酸性塩中リン酸ジルコニウムが最もよ く研究され，他のものはそれとかなり類似点があるので リン酸ジルコニウムについて比較的詳細に述べた.

\subsection{1 イオン交換の ideality イオン交換平衡に} ついての理論は無機イオン交換体に特有のものではない が，有機イオン交換体と異なる点で注意しなければなら ないのは交換体が rigid であり, 吸着イオンの相違によ る膨潤がほとんどない（約 1\%以下）ために立体効果が 著しいことである。また，すでに述べたように poly functional であるために交換基の解離が $\mathrm{pH}$ に依存する 可能性があることなどである. Ahland らは無機イオン 交換体の平衡について次のような平衡を提案している.

$$
\mathrm{HA}_{\mathrm{e}} \stackrel{K_{1}}{\rightleftarrows} \mathrm{H}_{\mathrm{e}^{+}}+\mathrm{A}_{\mathrm{e}^{-}}
$$




$$
\begin{aligned}
& \mathrm{M}_{\mathrm{s}^{n+}}+n \mathrm{H}_{\mathrm{e}}+\stackrel{K_{2}}{\rightleftarrows} n \mathrm{H}_{\mathrm{s}}{ }^{+}+\mathrm{M}_{\mathrm{e}}{ }^{n+} \\
& \mathrm{M}_{\mathrm{e}}{ }^{n+}+n \mathrm{~A}_{\mathrm{e}}-\stackrel{K_{3}}{\rightleftarrows} \mathrm{MA}_{n \mathrm{e}} \quad \cdots \cdots . .
\end{aligned}
$$

e および s はそれぞれ交換体中および溶液中のイオン 種を示す.

もし，金属イオン濃度がじゅうぶんに小さく，また測 定条件内で（1）の解離定数の变化が著しくない場合は

$$
\begin{aligned}
& \log K_{d}=n \mathrm{pH}+\log D \\
& D:\left[\mathrm{H}_{\mathrm{e}}{ }^{+}\right] K_{\mathbf{2}}\left\{1+K_{\mathbf{3}}\left[\mathrm{A}_{\mathrm{e}}{ }^{-}\right]^{n}\right\}=\text { Const. }
\end{aligned}
$$

となり, $\log K_{d}$ と $\mathrm{pH}$ の関係は傾斜 $n$ の直線を示すこ とになる. この $n$ は吸着状態のイオン種の価数を示す. 厳密な取り扱いによると溶液中および交換体中の活量で 示さなければならないし，また， $K_{1} や K_{3}$ が測定の濃 度範囲内において変化しないという条件が必要である. $K_{1}$ が異なる（すなわち異なった吸着 site がこの平衡系 に影響を与える）ことはじゅうぶんに予想される．特に 弱く解離している交換体は $\mathrm{pH}$ 依存性が大きい. 特に, 結晶イオン半径が大きく水和数の小さいイオンほど立体 効果の影響があるので異なった site の影響が大きく反映 することが考えられる. Ahrland によるとこの傾向は $\mathrm{Cs}^{+}>\mathrm{Rb}^{+}>\mathrm{Na}^{+}=0$ の順であり, Fig. 1 にみられるよ うに $\mathrm{Cs}^{+}$濃度が小さいほど $K_{d}$ 值は大となるが $\log K_{d}$ と $\mathrm{pH}$ の傾きに大きな影響をもたないことが多いことが 報告されている6). したがって，イオン交換樹脂の場合と 同様にイオン種の推定に応用することができ， $K_{d}$ 值が 非常に大きい場合, 濃厚な酸溶液中における微量イオン

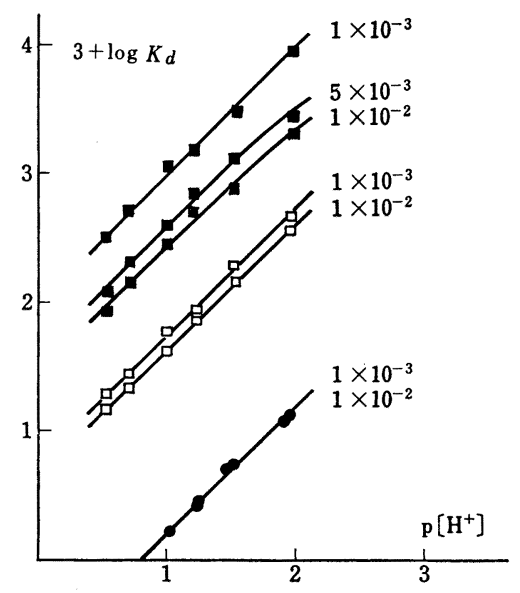

Fig. 1 Sorption at constant $C_{\mathrm{MG}}\left(\mathrm{mmole} \cdot \mathrm{g}^{-1}\right)$ of $\mathrm{Cs}^{+}, \mathrm{Rb}^{+}$, and $\mathrm{Na}^{+}$on $\mathrm{ZrP}$ of $(\mathrm{P} /$ $\mathrm{Zr})_{\mathrm{s}}=1.95$, ignition loss $45 \%$

$-0-\mathrm{Na}^{+} ;-\square-\mathrm{Rb}^{+}$
種の推定に利用することができる．その1 例を Table II に示す.すでに述べたように分布係数は目的成分の濃度 にも依存するために，各種金属イオンの分布係数の比を とって分離係数值とすることは有効ではなく，小なくと も多量電解質の濃度のほか目的成分の濃度または比放射 能を明記することが重要であると思われる．多量成分を 一定としたとき目的成分の $K_{d}$ の 濃度依存性は立体効果 が大きいほど大きいことが考えられる， $K_{d}$ の濃度依存 性のある $\mathrm{Cs}^{+}$や $\mathrm{Th}^{4+}$ よりももっと大きな影響をもつ と予想される $\mathrm{UO}_{2}^{2+}$ は期待に反してかなりの広い範囲 内で $K_{d}$ が一定となる.

Table II The sorption chloro-and nitrato-actinide complexes on zirconium phosphate exchanger ${ }^{336)}$

\begin{tabular}{clcl}
\hline \hline Metalion & Range of acidity & Slope & Species sorbed \\
\hline $\mathrm{Th}^{4+}$ & $4 \sim 8 M \mathrm{HNO}_{3}$ & 1.10 & $\mathrm{Th}\left(\mathrm{NO}_{3}\right)_{3}{ }^{+}$ \\
& $0.5 \sim 4 M \mathrm{HNO}_{3}$ & 2.25 & $\mathrm{Th}\left(\mathrm{NO}_{3}\right)_{2}{ }^{2+}$ \\
& $6 \sim 8 M \mathrm{HCl}$ & 1.13 & $\mathrm{ThCl}_{3}{ }^{+}$ \\
& $1 \sim 6 M \mathrm{HCl}$ & 2.07 & $\mathrm{ThCl}_{2}{ }^{++}$ \\
$\mathrm{U}^{4+}$ & $1 \sim 6 M \mathrm{HNO}_{3}$ & 1.15 & ${\mathrm{U}\left(\mathrm{NO}_{3}\right)_{3}{ }^{+}}$ \\
$\mathrm{UO}_{2}{ }^{2+}$ & $1 \sim 8 M \mathrm{HCl}_{3}$ & 1.24 & $\mathrm{UCl}_{3}{ }^{+}$ \\
& $1 \sim 8 M \mathrm{HNO}_{3}$ & 1.01 & $\mathrm{UO}_{2}\left(\mathrm{NO}_{3}\right)^{+}$ \\
$\mathrm{Pu}^{4+}$ & $1 \sim 8 M \mathrm{HCl}^{+}$ & 1.12 & $\mathrm{UO}_{2} \mathrm{Cl}^{+}$ \\
& $2 \sim 8 M \mathrm{HNO}_{3}$ & 1.03 & ${\mathrm{Pu}\left(\mathrm{NO}_{3}\right)_{3}{ }^{+}}$ \\
$\mathrm{PuO}_{2}{ }^{2+}$ & $0.7 \sim 2 M \mathrm{HNO}_{3}$ & 4.00 & $\mathrm{Pu}^{4+}$ \\
& $1 \sim 8 M \mathrm{HNO}_{3}$ & 1.12 & $\mathrm{PuO}_{2}\left(\mathrm{NO}_{3}\right)^{+}$ \\
\hline
\end{tabular}

この吸着機構は $\mathrm{UO}_{2}^{2+}$ のトレーサー量では主として イオン交換反応に基づくと考えられるが，この反応は非 可逆的であり $100 \%$ 回収は困難である ${ }^{119)}$.このほか $\mathrm{U}^{4+}, \mathrm{Th}^{4+}$ P $\mathrm{Pu}^{4+}$ などでもそのような非可逆性が知 られている6(158)236)324)326). $\mathrm{UO}_{2}{ }^{2+}$ の場合, リン酸 ジル コニウム $(\mathrm{ZrP})$ への吸着の研究から結晶やゲルの表面 に $\mathrm{UO}_{2} \mathrm{HPO}_{4} \cdot 4 \mathrm{H}_{2} \mathrm{O}$ 相が存在することが確かめられ ${ }^{324)}$ 326)，この吸着は沈殿反応を伴うことが確認された.しか しながら $\mathrm{UO}_{2}{ }^{2+}$ を強く保持しているのでこれを利用し て分析に応用できる. 同様に $\mathrm{WO}_{4}{ }^{2-}$ や $\mathrm{Mo}_{7} \mathrm{O}_{24}{ }^{6-}$ の $\mathrm{ZrP}$ 八の強い吸着もリン酸基との強い化学的相互作用 （共有結合生成や沈殿生成など）によるものと推定され る234).

2.1.2 酸性塩の安定性および 溶解性 無機イオン 交換体を分析化学的または工業的分離に応用するとき, i ）化学的安定性，ii）熱的安定性およびiii）それに伴 う選択性の変化が重要な問題となる.リン酸ジルコニウ 么の化学的安定性は酸性溶液中では比較的安定であるが アルカリ性溶液中で徐々に加水分解しリン酸イオンを放 出し, リン酸含量の少ないものに変化する欠点がある9) 14)220)。たとえばアルカリ金属イオン形 $\mathrm{ZrP}$ を水を加え 
たのち $100^{\circ} \mathrm{C}$ で還流を続けると加水分解が起こり，交 換容量が低下寸る，その結果として，新しい交換平衡に 達するまで余分のアルカリ金属イオンを溶液中に放出す る42). Baestle 19) らおよび Larsen204) らによると ZrP の ゲルをじゅうぶんに水洗すると $\mathrm{P}: \mathrm{Zr}=1.67$ となりそ れ以上はりン酸の遊離はほとんど認められなかったと述 べている、また，Vesely ${ }^{321}$ らによると 20\% リン酸溶液 中で $60^{\circ} \mathrm{C}$ で処理した場合, その生成物は加水分解の傾 向をもたず，イオン交換体の使用に影響しないと述べて いる. これは微結晶 $\mathrm{ZrP}$ はゲル状物と比べて加水分解 に対して安定であり,リン酸処理によって微結晶 $\mathrm{ZrP} に$ 変化したために安定となったものと思われる.

Horrvitz ${ }^{142)}$ によって加水分解の研究が 詳細になされ たが，上の傾向とよく一致した．しかし， P/Zr が 1.34 および 1.13 となると安定であり，0.1M 硝酸中でくり かえし処理すると $75^{\circ} \mathrm{C}$ において $4 \times 10^{-5} \mathrm{mmol}^{\mathrm{PO}_{4} / \mathrm{g}}$ で一定优を示した，すでに述べたように硝酸，硫酸およ びリン酸溶液中で安定であるが，リン酸含量があまり低 くなると含水酸化ジルコニウムの溶出が起こる. しかし これらリン酸イオンの溶出は結晶化度, $\mathrm{pH}$ や温度など によって異なってくる. また，安定性は吸着しているイ オン形によっても異なり $\mathrm{Li}^{+}<\mathrm{Na}^{+}<\mathrm{Ag}^{+}<\mathrm{K}^{+}<\mathrm{Rb}^{+}$ $<\mathrm{NH}_{4}{ }^{+}<\mathrm{Cs}^{+}$の順で，カリウム，ルビジウムやセシウ ム形ではりン酸イオンの溶出はほとえどない6(316). 4 価 金属のリン酸塩イオン交換体はすべて類似の傾向を示 す.しかし， SnP ではアルカリ性溶液に溶解する150)。

4 価金属のリン酸塩以外の酸性塩（たと光ばスズやチ タンを基体としたヒ酸, セレン酸, モリブデン酸, タング ステン酸およびアンチモン酸塩）の安定性については QureshiRg)らによって研究されている. Fig. 2-1 および Fig. 2-2 に示したように水中ではいずれも安定である が，硝酸溶液では溶解性が大となる，アンチモン酸塩や タングステン酸は他の塩に比較して非常に安定である.

特に $\mathrm{SnSb}$ は $\mathrm{Sb} / \mathrm{Sn}=1: 4 \sim 2: 1$ の間で酸およびアル カリの両方に安定である1)4157).

2.1.3 熱的安定性と耐放射線性無機イオン交換 の応用の可能性として高温水や溶融塩中でのイオン交換 やクロマトグラフィーが考えられ，高温で処理したあと での交換容量や選択性を比較することは非常に有意義で ある.

$\mathrm{ZrP}$ における熱的変化が最もよく研究されている10) 17) 34) 49) 243). 無定形 $\mathrm{ZrP}$ を加熱すると $130^{\circ} \mathrm{C}$ で $\mathrm{Zr}(\mathrm{HP}$ $\left.\mathrm{O}_{4}\right)_{2}$ の無水物が得られ，結合水の脱水とそれにともなう $\mathrm{P}-\mathrm{O}-\mathrm{P}$ の結合生成によるピロリン 酸基の生成は〜 180 ${ }^{\circ} \mathrm{C}$ 以上の 温度から始まる ${ }^{17) 34)}, 200^{\circ} \mathrm{G}$ で交換容量の

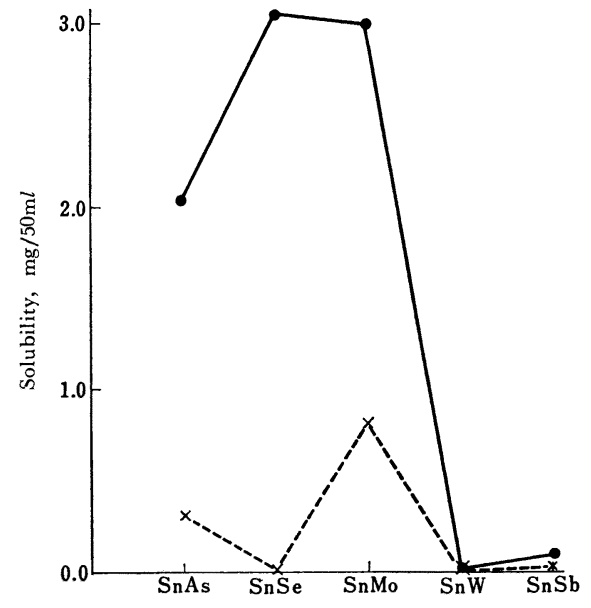

Fig. 2-1 Chemical stability of tin (IV) based exchangers

$-\bullet-4 M \mathrm{HNO}_{3} ;---\times--\mathrm{H}_{2} \mathrm{O}$

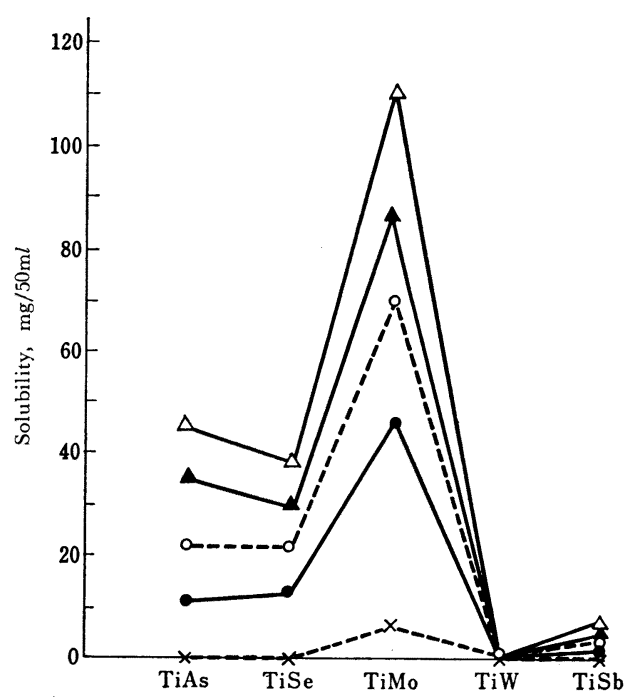

Fig. 2-2 Chemical stability of titanium(IV)-based exchangers

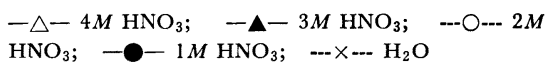

$13.8 \%$ が減少する．無定形 $\mathrm{ZrP}$ の交換容量は減少する が，分布係数 $K_{d}$ の減少の割合は一定ではなく $\mathrm{Bi}^{3+}$ や $\mathrm{Th}^{4+}$ の上うに急激に 減少するものやアルカリ金属の ようにあまり減少しないものもある8)172 243) 3193321325). Alberti らによると $260^{\circ} \mathrm{G}$ で $\mathrm{ZrP}$ を1時間加熱したも のの $\mathrm{Cs}^{+}$の $K_{d}$ は $50^{\circ} \mathrm{C}$ で $24 \mathrm{hr}$ 加熱したものの約 8 倍大きくなった ${ }^{17)}$. 多分水含量がジルコニウムに対して 
1 モルのとき乾燥温度 $\left(190^{\circ} \mathrm{C}\right)$ で最大の $\mathrm{Cs}^{+}$の $K_{d}$ 值 を示し, $\mathrm{UO}_{2}{ }^{2+}$ や $\mathrm{Ce}^{2+}$ ではあまり変化しない8)。それ 以上の温度では減少する.同様な結果が $\mathrm{ZrP} へ$ へ $\mathrm{K}+$ の $K_{d}$ でみられ $160^{\circ} \mathrm{C}$ で最小となり $300^{\circ} \mathrm{C}$ 付近で急激に 大となり前者の約 $10^{3}$ 倍に増大する ${ }^{39)}$. これはし 結合生成するより低い温度では層間に存在していた水分 子を放出させることによって $\mathrm{Cs}^{+}$の吸着性が増加した と考えられる.しかしながら, 結晶性や微結晶性 Z rP で は同様な熱処理や $270^{\circ} \mathrm{C}$ でのオートクレーブ処理でも このような縮合は観察されない， $450^{\circ} \mathrm{C}$ で加熱するとは じめの交換容量の $58.8 \%$ に減少する。アルカリ金属イ オン形ではさらに安定で溶融塩中のイオン交換反応を研 究することができる. このときのイオン交換等温線は水 溶液中や $300^{\circ} \mathrm{C}$ の溶融滥中でみられた hysterisis がみら れず $450^{\circ} \mathrm{C}$ の $(\mathrm{Na}-\mathrm{K}) \mathrm{NO}_{3}$ 塩中では ideal な交換が起 きる.

熱水中ではさらに安定であり $250^{\circ} \mathrm{C}$ まで上げて分布 係数が測定でき, 水溶液中での熱力学的数值をとるのに 便利である ${ }^{290)}$. また高温水の 純化への応用も期待され る12).

他の酸性塩では酸と塩基の 組み合わせによって 異な

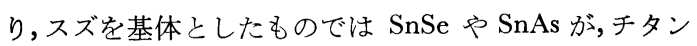
を基体としたものは TiSb や TiV などが安定で 300〜 $500^{\circ} \mathrm{C}$ まで交換容量はあまり变わらない (Fig. 3-1 およ び Fig. 3-2)

有機イオン交換樹脂に $10^{9} \mathrm{rad}$ オーダーの $\gamma$ 線を照射 すると $25 \%$ 交換容量が減少し油状物になる. ZrP38) 344), SnP148), AMP299), SnFC, ZrFC, CeSb, TiSb や CeW 129)などに同じオーダーの $\gamma$ 線を照射しても交換容黑, 溶

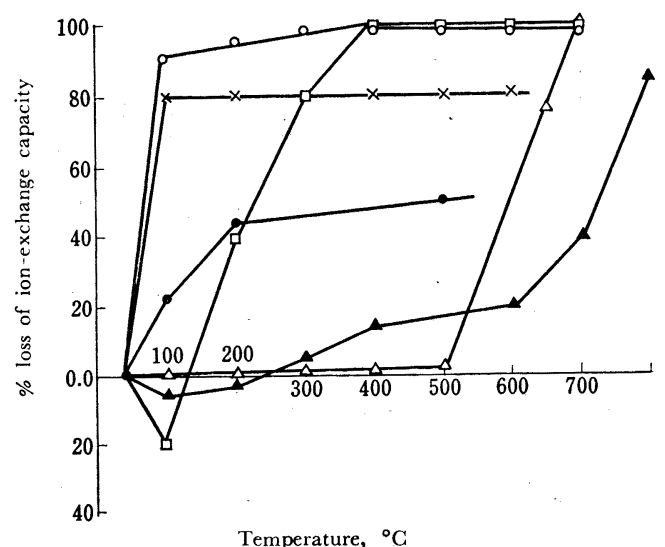

Fig. 3-1 Thermal stability of tin(IV)-based exchangers

- - SnSb; - $\times$ - SnW; - - - $-\mathrm{SnAs} ;-\mathrm{O}-\mathrm{SnMo}$; $-\mathrm{SnP} ;-\triangle-\mathrm{SnSe}$

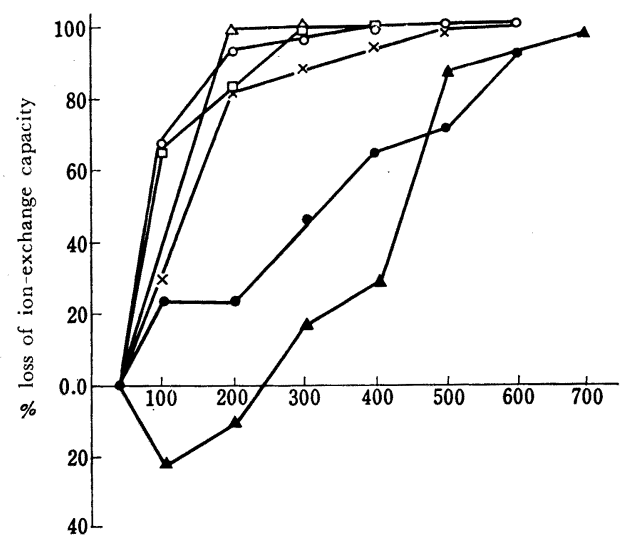

Temperature, ${ }^{\circ} \mathrm{C}$

Fig. 3-2 Thermal stability of titanium(IV)-based exchangers

$-\mathrm{O}$ - TiSb; $-\times-\mathrm{TiW} ;-\mathrm{O}-\mathrm{TiAs} ;-\mathrm{O}-\mathrm{TiSe}$
$-\triangle-\mathrm{TiMo} ;-\boldsymbol{\Delta}-\mathrm{TiV}$

解性や選択性にほとえど変化を与えない，このことが放 射化学的分離剂として期待される性質の一つであるとい 光る.

2.1.4 各種酸性塩のイオンふるい効果 4 価金属 のリン酸塩や七酸塩は浱厚な酸溶液中やフッ化水素酸溶 液中で還流するとリン酸ジルコニウムの結晶性のものと 類似した層状構造をもつイオン交換体が得られる.いず れも陽イオン交換性をもち，それらの組み合わせによっ て層間距離の異なったものが得られる. Table III に示 したように $\beta-\mathrm{ZrP}$ までは $\mathrm{Na}^{+}$から $\mathrm{Cs}^{+}$までよく吸 着するが，層間距離が $0.91 〜 0.776 \mathrm{~nm}$ までは結晶イ

Table III Comoarison between the first interplanar distance and ion-exchange properties of the salts of the type $\left.\mathrm{MIV}^{\mathrm{IV}}\left(\mathrm{HXO}_{4}\right)_{2} \cdot \mathrm{yH}_{2} \mathrm{O}^{\mathrm{R} 6}\right)$

\begin{tabular}{lcl}
\hline \multicolumn{1}{c}{ Exchanger } & $\begin{array}{c}\text { First interplanar } \\
\text { distance }(\mathrm{nm})\end{array}$ & $\begin{array}{c}\text { Alkali metal cation } \\
\text { exchanged by the } \\
\mathrm{H}^{+} \text {form }\end{array}$ \\
\hline $\mathrm{Zr}\left(\mathrm{HPO}_{4}\right)_{2} \cdot 2 \mathrm{H}_{2} \mathrm{O}(\gamma-\mathrm{ZrP})$ & 1.220 & $\mathrm{Na}-\mathrm{Cs}$ \\
$\mathrm{Th}\left(\mathrm{HPO}_{4}\right)_{2} \cdot 3 \mathrm{H}_{2} \mathrm{O}$ & 1.147 & $\mathrm{Na}-\mathrm{Cs}$ \\
$\mathrm{Ce}\left(\mathrm{HPO}_{4}\right)_{2} \cdot \mathrm{H}_{2} \mathrm{O}$ & 1.095 & $\mathrm{Li}, \mathrm{Na}, \mathrm{K}, \mathrm{Rb}, \mathrm{Cs}$ \\
$\mathrm{Zr}\left(\mathrm{HPO}_{4}\right)_{2}(\beta-\mathrm{ZrP})$ & 0.940 & $\mathrm{Na}-\mathrm{Cs}$ \\
$\mathrm{Ce}\left(\mathrm{HAsO}_{4}\right)_{2} \cdot \mathrm{H}_{2} \mathrm{O}$ & 0.910 & $\mathrm{Li}, \mathrm{Na}, \mathrm{K}$ (partry) \\
$\mathrm{Zr}\left(\mathrm{HAsO}_{4}\right)_{2} \cdot \mathrm{H}_{2} \mathrm{O}$ & 0.780 & $\mathrm{Li}, \mathrm{Na}, \mathrm{K}, \mathrm{Cs}$ (partly) \\
$\mathrm{Sn}\left(\mathrm{HAsO}_{4}\right)_{2} \cdot \mathrm{H}_{2} \mathrm{O}$ & 0.777 & $\mathrm{Li}, \mathrm{Na}, \mathrm{K}$ (partly) \\
& & $\mathrm{Cs}($ partly) \\
$\mathrm{Ti}\left(\mathrm{HAsO}_{4}\right)_{2} \cdot 2 \mathrm{H} \mathrm{H}_{2} \mathrm{O}$ & 0.777 & $\mathrm{Li}, \mathrm{Na}, \mathrm{K}$ \\
$\mathrm{Sn}\left(\mathrm{HPO}_{4}\right)_{2} \cdot \mathrm{H}_{2} \mathrm{O}$ & 0.776 & $\mathrm{Li}, \mathrm{Na}, \mathrm{K}, \mathrm{Cs}$ (partly) \\
$\mathrm{Zr}\left(\mathrm{HPO}_{4}\right)_{2} \cdot \mathrm{H}_{2} \mathrm{O}(\alpha-\mathrm{ZrP})$ & 0.760 & $\mathrm{Li}, \mathrm{Na}, \mathrm{K}$ \\
$\mathrm{Ti}\left(\mathrm{HPO}_{4}\right)_{2} \cdot \mathrm{H}_{2} \mathrm{O}$ & 0.756 & $\mathrm{Li}, \mathrm{Na}$ \\
$\mathrm{Th}\left(\mathrm{HAsO}_{4}\right)_{2} \cdot \mathrm{H}_{2} \mathrm{O}$ & 0.705 & $\mathrm{Li}$ \\
\hline
\end{tabular}


オン半径が大きいイオンは部分的にしか吸着しない. 層 間距離 $0.705 \mathrm{~nm}$ の $\mathrm{Th}\left(\mathrm{HAsO}_{4}\right) \cdot \mathrm{H}_{2} \mathrm{O}$ は $\mathrm{Li}^{+}$のみし か吸着しない。すでに述べたように $\mathrm{Zr}-\mathrm{O}-\mathrm{Zr}$ の層とも う一つの $\mathrm{Zr}-\mathrm{O}-\mathrm{Zr}$ 層間距離が直接的に問題となるので はなく, 層間の cavity にはいる空の大きさが重要であ る. $\mathrm{ZrP}$ を除く他の酸性塩の構造は正確にはわかってい ないが，層間距離に衤（正確には side）の大きさが比例 していると推定されている.

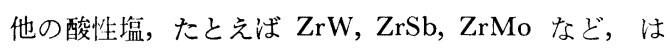
正確な層状構造や結晶構造をもたないために顕著なイオ ンふるい効果をもたない，これは構造が random であ るために多くの不完全構造があり，大きなイオンでも欠 けた cavity の中に容易に到達できるためと考えられる. しかしながら random 構造をもつ微結晶性のものまた は無定形のもののなかには pore size も randam であ り，微量イオンの吸着においてイオンふるい効果がある ことはじゅうぶんに考えられる.たとえば SnSbに対し て強い $\mathrm{Li}^{+}$の吸着が認められる3).

2.1.5 酸性塩の選択性立ふるい効果が存在 しない場合, 有機イオン交換体よりも顕著な選択性が観 察される.これらの選択性は多くの研究者によって考察 がなされているが，じゅうぶんな理解には達してはいな い.ゲル状の酸性塩では大ざっぱにいって Schulz-Hardy 則に従っているが，個々の交換体を注意深く検討す るとそれぞれの交換体に特有な選択性が認められる. 一 般的にいって，イオン交換樹脂と同様な固溶体と考元る と，それと無機イオン交換体との違いはその膨潤生の相 違である.すな轨ち，無機イオン交換体は非常に rigid で高架橋度の交換体と考えることができる．したがって 膨潤性はきわめて小さいため水中にある金属イオンの水 和半径を保って交換できる可能性は少なく, 全部をたは 一部の水和水を放出して吸着している104).

Gregor のモデル加らの熱力学的考察から選択係数 $K^{\prime}{ }_{B / A}$ は

$$
R T \ln K_{\mathrm{B} / \Lambda}=\pi\left(\bar{v}_{\mathrm{A}}-\bar{v}_{\mathrm{B}}\right)
$$

で表わされる135).ここに $\bar{v}_{\mathrm{A}}, \bar{v}_{\mathrm{B}}$ は吸着イオンの部分 モル体積， $\pi$ は膨潤圧である. 無機イオン交換体では $\pi$ の值は非常に大きくまた cavity が小さいために 水和部 分モル体積の差は大きいことが考えられ選択性が増大す る*. 4 価金属の酸性塩のアルカリ金属の選択性は有機 イオン交換樹脂と比較して著しく大きい.

無機イオン交換体の選択性の考察は Gregor モデルよ

* 結晶性フンチモン酸はゼオライト構造をもつと考え られ選択性の大きい順に格子定数が小さくなる2).
りも Eisenman ${ }^{110)}$ の理論のほうが次の点で merit があ る.

（1）水和イオンの半径や体積よりも，エネルギーの 単位で第一義的に近似される.

(2) 固定イオンと吸着イオンとの静電気的エネルギ 一を考虑している.

この考元方はガラスやゼオライトにおける選択性の逆 転現象などをよく説明することができた.

特にこの考元方は交換基における個性をよく反映する 各種酸性塩には有効な説明になりうると思われる.

無機イオン交換体の選択性洨交換体の組成によって変 化し, 一般的にいって交換容量が増大すると選択性も増 大するように思元る。しかしながら，それらの選択性は 単に組成のみではなく, 出発原料, 調製条件, 吸着時の $\mathrm{pH}$ や吸着イオンの濃度などによっても異なる. 特に調 製条件などには入念な注意が必要で, Szirtesにより TiP $\mathrm{ZrP}$ ○ $\mathrm{Cr}$ についてそれらのイオン交換性が比較され ている309).

\section{2 ジルコニゥムの塩類}

2.2.1 ZrP 古くはジルコニウムの定量分析に ZrP として沈殿させる方法がある. ジルコニウムのオキシ塩 化物の水溶液にリン酸を加えると添加比, 濃度や $\mathrm{pH}$ に よって $\mathrm{P} / \mathrm{Zr}$ 比の異なった沈殿が得られる．他の 4 価金 属のリン酸掹もほぼ類似の挙動を示す.初期に得られた ものは無定形または微結晶の集合体として得られ，再現 性のある結果が得られず著者によって異なったイオン交 換性が報告された. 研究が進むに従って $\gamma-\mathrm{ZrP}$ や $\alpha-$ $\mathrm{ZrP}$ の結晶性のものが見いだされそれらのイオン交換性 が明らかになってきている. 無定形 ZrP は Fig. 4 に 示したようになだらかな $\mathrm{pH}$ 滴定曲線を示すのに対し て, 結晶性 $\mathrm{ZrP}$ では 2 段に顕著な飛躍が認められる. 後者を水酸化セシウムで滴定すると blank のそれとほと んど同じ曲線となり，Cs+をほとんど吸着しないことを 示す. 同様に水酸化ストロンチウムによる $\mathrm{pH}$ 滴定曲線 は約 $6 \mathrm{meq} \mathrm{OH}-/ \mathrm{g}$ から飛躍が起こるのに対して水酸化 バリウムのそれは水酸化セシウムで認められたと同じ $\mathrm{pH}$ 滴定曲線を示す ${ }^{88)}$. 同様に $\mathrm{Ba}^{2+}$ に対してもイオン ふるい効果が認められる。

2.2.2 結晶性 ZrP Table IV に示したように調 製条件によって種々のリン酸ジコニウムが得られる. その中で最も代表的なものは単結晶の合成に成功物した $\alpha-\mathrm{ZrP}$ で Fig. 5 に示したように層状構造をなしている 89). $\mathrm{P} 21 / \mathrm{c}$ の空間群に属し, 単位胞は Table IV に示し たように $\alpha$ - ZrP $\alpha$ - ZrAs および $\alpha$-TiP ともに類似し 
Table IV Crystalline zirconium phosphate phases which exhibit ion exchange properties ${ }^{\mathrm{R} 2)}$.

\begin{tabular}{|c|c|c|c|}
\hline Formula & Propesed desingnation & Interlayer spacing $(\AA)$ & Method of preparation \\
\hline $\mathrm{Zr}\left(\mathrm{HPO}_{4}\right)_{2} \cdot \mathrm{H}_{2} \mathrm{O}$ & $\alpha-\mathrm{ZrP}$ & 7.56 & Reflux $\mathrm{ZrP}$ gel in $10 \sim 15 \mathrm{M}$ phosphoric acid \\
\hline $\mathrm{Zr}\left(\mathrm{HPO}_{4}\right)_{2}$ & $\beta-\mathrm{ZrP}$ & 9.4 & Dry $\gamma$-ZrP \\
\hline $\mathrm{Zr}\left(\mathrm{HPO}_{2}\right)_{2} \cdot 2 \mathrm{H}_{2} \mathrm{O}$ & $\gamma-\mathrm{ZrP}$ & 12.2 & Reflux $\mathrm{ZrP}$ gel in acid solution of sodium phosphate \\
\hline $\mathrm{Zr}\left(\mathrm{HPO}_{4}\right)_{2} \cdot 1 / 2 \mathrm{H}_{2} \mathrm{O}$ & $\delta-\mathrm{ZrP} \dagger$ & 7.13 & Reflux $\mathrm{ZrP}$ gel in enriched phosphoric acid \\
\hline $\mathrm{Zr}\left(\mathrm{HPO}_{4}\right)_{2}$ & $\varepsilon-\mathrm{ZrP} \dagger$ & 5.59 & Reflux ZrP gel in enriched phosphoric acid \\
\hline $\mathrm{Zr}\left(\mathrm{HPO}_{4}\right)_{2}$ & $\zeta-\mathrm{ZrP}$ & 7.41 & Heat $\alpha-\mathrm{ZrP} \quad 100 \sim 200^{\circ} \mathrm{C}$ \\
\hline $\mathrm{Zr}\left(\mathrm{HPO}_{4}\right)_{2}$ & $\eta$-ZrP & 7.34 & Heat $\alpha-\mathrm{ZrP} 250 \sim 300^{\circ} \mathrm{C}$ \\
\hline $\mathrm{Zr}\left(\mathrm{HPO}_{4}\right)_{2} \cdot 8 \mathrm{H}_{2} \mathrm{O}$ & $\theta-\mathrm{ZrP}$ & 10.4 & Wash $\mathrm{Zr}\left(\mathrm{NaPO}_{4}\right)\left(\mathrm{HPO}_{4}\right) \cdot 5 \mathrm{H}_{2} \mathrm{O}$ with acid \\
\hline Not established & $i-\mathrm{ZrP}$ & 7.73 & Wash $\mathrm{Zr}\left(\mathrm{NaPO}_{4}\right)_{2}$, phase $\mathrm{H}$, with acid \\
\hline Not established & $k-\mathrm{ZrP}$ & 6.11 & Dissolve $\alpha-\mathrm{ZrP}$ in $\mathrm{HF}$, boil and add $\mathrm{SiO}_{2}$ \\
\hline Not established & $\mathrm{PO}_{4} / \mathrm{Zr}=2.2 \dagger$ & & $\mathrm{ZrOCl}_{2} \cdot 8 \mathrm{H}_{2} \mathrm{O}+$ fused $\mathrm{H}_{3} \mathrm{PO}_{4}$ at $100 \sim 120^{\circ} \mathrm{C}$ \\
\hline $\mathrm{Zr}\left(\mathrm{HPO}_{4}\right)\left(\mathrm{H}_{2} \mathrm{PO}_{4}\right)_{2}$ & $\alpha-\mathrm{ZrTP}$ & & $\mathrm{ZrOCl}_{2}$ (Anhyd) + fused $\mathrm{H}_{3} \mathrm{PO}_{4}$ at $85^{\circ} \mathrm{C}$ \\
\hline $\mathrm{Zr}\left(\mathrm{HPO}_{4}\right)\left(\mathrm{H}_{2} \mathrm{PO}_{4}\right)_{2}$ & $\beta$-ZrTP & & $\mathrm{ZrOCl}_{2} \cdot 8 \mathrm{H}_{2} \mathrm{O}+$ fused $\mathrm{H}_{3} \mathrm{PO}_{4}$ at $70^{\circ} \mathrm{C}$ \\
\hline
\end{tabular}

$\dagger$ Ion exchange behavior has not yet been firmly established.

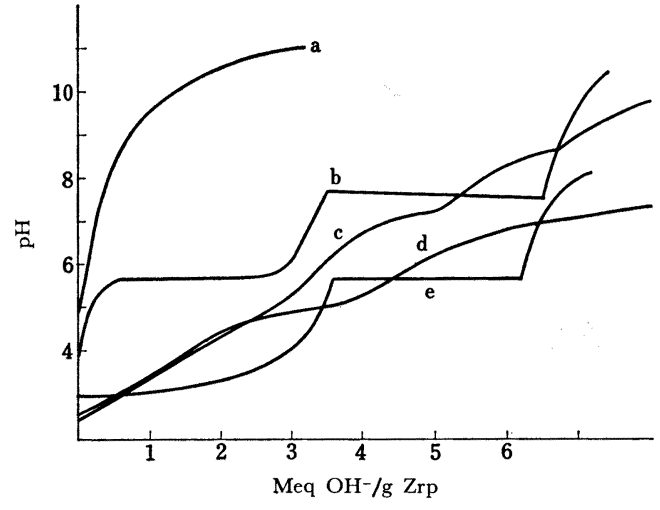

Fig. 4 Potentiometric titration curves for zirconium phosphates of different crystallinities Curve a : Crystalline $\mathrm{Zrp}$ titrated with $0.1 \mathrm{M} \mathrm{CsOH}$; Curve b : Crystalline $\mathrm{ZrP}$ titrated with $0.1 \mathrm{M} \mathrm{NaOH}$; Curve $\mathrm{c}$ : Gelatinous $\mathrm{Zrp}$ titrated with $0.1 \mathrm{M} \mathrm{NaCl}+$ $0.1 M \mathrm{NaOH}$; Curve $\mathrm{d}:$ Semi-crystalline $\mathrm{ZrP}$ titrated with $0.1 \mathrm{M} \mathrm{NaOH}$; Curve e : Crystalline ZrP titrated with $0.1 M \mathrm{NaCl}+0.1 M \mathrm{NaOH}$

ている. $\alpha-\mathrm{ZrP}$ の層間距離は $0.756 \mathrm{~nm}$ でリンはジル コニウムからなる面の上下にジグザグに約 $0.12 \mathrm{~nm}$ 離 れて位置し，リン酸基の三つの酸素はジルコニウムと等 間隔に結合し, 残りの酸素はジルコニウムの真上に位置 している. の部分に cavity が存在し，層に垂直な $\mathrm{Zr}-\mathrm{O}-\mathrm{P}-\mathrm{O}-\mathrm{Zr}-\mathrm{O}-\mathrm{P}-\mathrm{O}$ side と, ジルコニウム面を斜め に切るような $\mathrm{Zr}-\mathrm{O}-\mathrm{P}-\mathrm{O}-\mathrm{Zr}-\mathrm{O}-\mathrm{P}-\mathrm{O}$ face の二つの 入 口が存在し前者のほうが大きい. この空は $0.263 \mathrm{~nm}$ の 直径をもつ球状のイオンを通すことができる. Fig. 5 で ジルコニウムに垂直な $\mathrm{P}-\mathrm{OH}$ はの中央に位置する水 分子と $\mathrm{P}-\mathrm{O}-\mathrm{H}-\mathrm{O}{ }_{\mathrm{H}}^{\mathrm{H}}$ の結合が生成していると推定され ている.

多少の格子振動があったとしても, 結晶イオン直径が
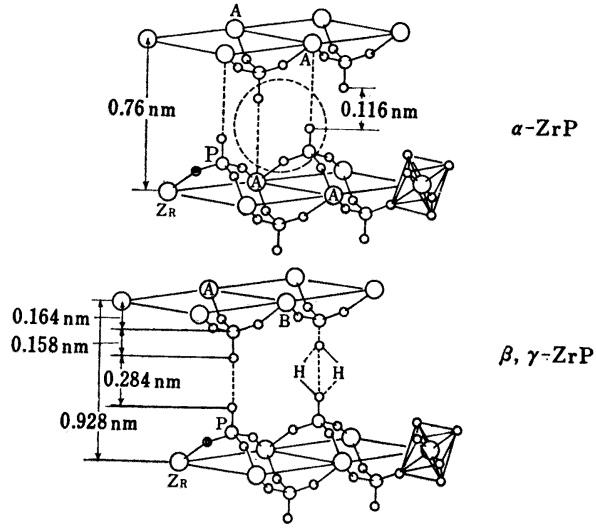

Fig. 5 Schematic illustration of the structure of $\alpha, \beta$ and $\gamma$-zirconium phosphate Dashed circle : Interlayer cavity

大きいセシウム $(0.334 \mathrm{~nm})$ やルビジウム $(0.296 \mathrm{~nm})$ は吸着せず，リチウム $(0.136 \mathrm{~nm})$ ，ナトリウム $(0.196$ $\mathrm{nm})$ やカリウム $(0.266 \mathrm{~nm})$ を吸着することができ る86)*. 事実, Fig. 5 にみられるように $\mathrm{Cs}^{+}$はほとえど 吸着せず高いアルカリ性溶液からのみ吸着されるにすぎ ない.このようなイオンふるい効果は他の 4 価金属の酸 性塩（結晶性）でも観察され，ThAs ではリチウムに対 してのみ選択性が認められることは分析化学的にも非常 に多彩な応用が期待される.

$\alpha-\mathrm{ZrP}$ のイオン交換性で興味あることは $\mathrm{pH}$ 滴定曲

* 無機イオン交換体の吸着は水和イオン半径よりも結 晶イオン半径のほうがより重要であり, 水溶液中の 水和水の一部を放出して吸着する場合が多い109). た空を通過するときには空に垂直な方向の水和水を 放出してはいらないと吸着現象が説明しにくくな る. 
線に hysteresis が羿められる点である.たとえば，バッ チ法で水素形の $\alpha-\mathrm{ZrP}$ 喪 $0.1 M$ 塩化ナトリウム +0.1 $M$ 水酸化ナトリウムで滴定すると連続的に変比するの ではなく， $\alpha-\mathrm{Z} \cdot \mathrm{P}$ 相と半分交換された 5 水和物 $\mathrm{Zr}(\mathrm{Na}$ $\left.\mathrm{PO}_{4}\right)\left(\mathrm{HPO}_{4}\right) \cdot 5 \mathrm{H}_{2} \mathrm{O}$ の相が存在し滴定度に応じて相の量 比が変化する. 半交換点で $\mathrm{pH}$ 飛躍があり, その後 5 水 和物と完全に交換された相とが共存し, 最終的には $\mathrm{Zr}$ $\left(\mathrm{NaPO}_{4}\right)_{2} \cdot 3 \mathrm{H}_{2} \mathrm{O}$ 相のみとなる. これを $0.1 M$ 塩化ナ トリウムと $0.1 M$ 水酸化ナトリウムで滴定すると $\mathrm{Zr}$ $\left(\mathrm{NaPO}_{4}\right)\left(\mathrm{HPO}_{4}\right) \cdot 5 \mathrm{H}_{2} \mathrm{O}$ になったのち, さらに滴定を続 けると $\alpha-\mathrm{Z}: \mathrm{P}$ にはもどらず層間距離が $1.04 \mathrm{~nm} の \theta-$ $\mathrm{ZrP}\left\{\mathrm{Zr}\left(\mathrm{HPO}_{4}\right)_{2} \cdot 8 \mathrm{H}_{2} \mathrm{O}\right\}$ との混合物が得られる.これは reversible ではなく加熱によってもとの $\alpha-\mathrm{ZrP}$ にもど る.

$$
\begin{aligned}
& \mathrm{Zr}\left(\mathrm{HPO}_{4}\right)_{2} \cdot \mathrm{H}_{2} \mathrm{O}+\mathrm{Na}+\rightleftarrows \mathrm{Zr}\left(\mathrm{NaPO}_{4}\right)\left(\mathrm{HPO}_{4}\right) \cdot \mathrm{H}_{2} \mathrm{O}
\end{aligned}
$$

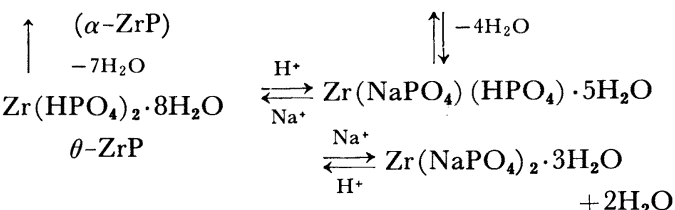

半分交換したものの層間距離は $(1.18 \mathrm{~nm}$ であり $\theta-$ $\mathrm{ZrP}$ は $1.04 \mathrm{~nm}$ であるためにセシウムを交換すること ができる.

リン酸ナトリウムの酸性溶液と無定形 $\mathrm{ZrP}$ をいっし ょに還流すると，層間距離 $1.22 \mathrm{~nm}$ の $\gamma \mathrm{ZrP}$ が得ら れる.これは ZrP 中最も層間距離が長く, すべてのア ルカリ金属イオンを吸着することができる・ $\gamma-\mathrm{ZrP}$ は $\beta-\mathrm{ZrP}$ と同形で $-\mathrm{P}-\mathrm{O} \ddots_{{ }_{\mathrm{H}}}^{\mathrm{H}} \cdot \mathrm{O}-\mathrm{P}-$ の結合をもち含水 状態だけが異なっている. $\beta-\mathrm{ZrP}$ を水や空気中の水蒸気 と接すると $\gamma-\mathrm{ZrP}$ に変わり, 硫酸カルシウム上で乾燥 すると $\beta-\mathrm{ZrP}$ となる. したがって水中に存在するとき は $\gamma-\mathrm{ZrP}$ となっている.これは $\mathrm{Li}^{+}$から $\mathrm{Cs}^{+}$までの アルカリ金属イオンを吸着することができ，いわゆるイ オンふるい効果は認められない.

無定形リン酸ジルコニウムはジルコニウム(IV) の可 溶性塩にリン酸溶液を加えることによって得られる．生 成した沈殿はゲル状で沪過しにくい，このままでは交換 体としては不適当であるが，乾燥条件や調製条件を選ぶ ことによってカラムに適するような塊状にすることがで きる. 一般に完全に無定形の沈殿を調製することはむし ろ困難で X 線回折図形上で 3〜4 の弱い回折線が見い だされる. 通常の調製条件では微結晶と無定形との混合 物として得られやすい. $\mathrm{P} / \mathrm{Zr}$ の比は 0 ～2.0 まで変化
し，結晶性 $\mathrm{ZrP}$ と同じ組成の 2.0 の 值に達することが できる。

Baetsle らによってジルコニウムが四つ重合した鎖に リン酸基が結合した式が提案されている48).

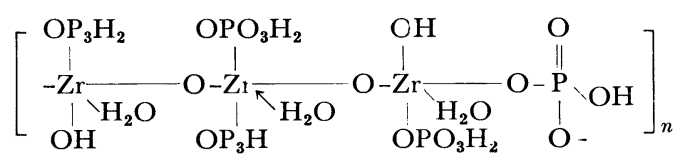

しかしながらゲル表面に二塩基性リン酸基とジルコニ ウムと結合した 水酸基が共存することは滴定曲線の結 果からも受け入れられない. 急速に沈殿を生成させたも

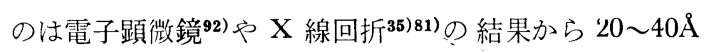
程度と考えられ, 層間距離を示す (200) 面も broad で しかも小さい $2 \theta$ で回折する. しかし基本的には結唱性 $\mathrm{ZrP}$ と類似している. アルキルアンモニウム塩の吸着の 研究から，アルキル基の size の増加とともに吸着や飽 和交換容量が減少した40). これはゲル状 ZrP が cavity ヘの入口が違った大きさをもち，それが randam に存在 しているという考えを支持している. ゲル結晶のこのふ ぞろいは水素結合の結合エネルギーにある範囲を与え, 酸強度において異なった site が存在するようになる. このことは IR スペクトルの測定から, OH 伸縮振動が 結晶性 ZrP では四つの独立した吸収をもつのに対して， ゲル状 ZrP では一つの broad な吸収帯が観察される ことから支持される. このように異なった酸強度の存在 のため Fig. 4 に見られるように poly functional な滴 定曲線をなすものと考えられている. このような randam 構造のために, cavity へ入口だけではなく cavity そのものが一部欠けたものも多数存在すると想像する ことができ，大きなイオン（たとえば $\mathrm{Cs}^{+} ）$ も容易に交 換可能となるであろう*. したがって立体効果はあって もイオンふるい効果をもつ可能性は非常に少ない. 事 実, かなり大きな第 4 級アンモニウム塩もよく吸着する. 交換容量は中性またはアルカリ性溶液中で 5〜6 meq/g である. $100^{\circ} \mathrm{G}$ 前後で加熱した amorphous に近い ZrP はジルコニウムに対して 1 モルの水をもち，この組成で の $\mathrm{Cs}^{+}$の $K_{d}$ が急激に増大する. この組成では $\mathrm{Na}^{+}$の $K_{d}$ の増加はあまり大きくなく，この温度で処理したも のは分離係数が大となる ${ }^{11)}$.

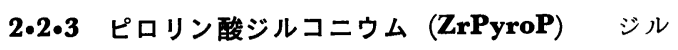
コニウム塩溶液にピロリン酸ナトリウムを加えて硝酸酸 性にすると得られる100)230). $\mathrm{pH}$ などによって組成 $(\mathrm{P} / \mathrm{Zr}$

* 結晶性 $\mathrm{ZrP}$ でもその表面は不完全 cavity が存在す るが表面積が小さいために非常に少ないと考えられ る・ 
Table VI Composition, capacity and selectivity of various inorganic ion-exchangers

\begin{tabular}{|c|c|c|c|}
\hline Exchanger & Composition & Gapacity & Selectivity series \\
\hline \multicolumn{4}{|l|}{ Zirconium based } \\
\hline \multirow[t]{8}{*}{$\begin{array}{l}\text { Zirconium phosphate (ZrP) } \\
\text { (amorphous) }\end{array}$} & $\mathrm{P} / \mathrm{Zr}=0.5 \sim 2.1$ & $0.6 \sim 2.0 \mathrm{meq} / \mathrm{g}(\mathrm{pH}=7)$ & $\underset{\mathrm{Ba}^{42} 2(205) 2321}{\mathrm{Cs}^{+}>\mathrm{Rb}^{+}>\mathrm{Ka}^{+}>\mathrm{Na}^{+}}, \mathrm{Mg}^{2+}>\mathrm{Ca}^{2+}>\mathrm{Sr}^{2+}>$ \\
\hline & & & $\left.\mathrm{Zn}<\mathrm{Cu}(\mathrm{II})>\mathrm{Ni}>\mathrm{Co}^{26}\right)$ \\
\hline & $\mathrm{P} / \mathrm{Zr}=2.02$ & $5 \sim 6 \mathrm{meq} / \mathrm{g}(\mathrm{pH}=12)$ & $\mathrm{Cs}>\mathrm{Rb}>\mathrm{Eu}^{3+}>\mathrm{Sr}^{11}$ \\
\hline & & & $\begin{array}{l}\mathrm{Ce}(\mathrm{IV})>\mathrm{U}(\mathrm{VI})>\mathrm{Cf}>\mathrm{Eu}(\mathrm{III})>\mathrm{Cm}(\mathrm{III})> \\
\left.\mathrm{Am}(\mathrm{III})>\mathrm{Ce}(\mathrm{III})^{142}\right)\end{array}$ \\
\hline & & & $\left.\mathrm{Cs}>\mathrm{Ce}(\mathrm{III})>\mathrm{Sr}>\mathrm{Na}(\mathrm{pH}=0 \sim 2)^{142}\right)$ \\
\hline & & & $\mathrm{Fe}(\mathrm{III})>\operatorname{Cr}(\mathrm{III})>\mathrm{Ce}(\mathrm{III})>\mathrm{Y}(\mathrm{III})^{11}$ \\
\hline & & & $\mathrm{Li}>\mathrm{Na} \gg \mathrm{K}$ (in fused salt) $\left.{ }^{15}\right)$ \\
\hline & & & $\left.\mathrm{UO}_{2}{ }^{2+}>\mathrm{Ce}(\mathrm{III})>\mathrm{Sr}^{6}\right)$ \\
\hline (semicrystalline) ${ }^{238}$ ) & $\mathrm{P} / \mathrm{Zr}$ & & $\mathrm{Cs}>\mathrm{H}>\mathrm{K}>\mathrm{Li}(0.1 M \mathrm{MCl}+\mathrm{HCl})$ \\
\hline$(\text { crystalline })^{35)}$ & $\mathrm{Zr}\left(\mathrm{HPO}_{4}\right)_{2} \cdot \mathrm{H}_{2} \mathrm{O}$ & & $\mathrm{UO}_{2}{ }^{2+}>\mathrm{Ce}(\mathrm{III})>\mathrm{Na}>\mathrm{Cs}(\mathrm{pH}=2)$ \\
\hline \multirow{2}{*}{$\begin{array}{l}\text { Zirconium pyrophosphate } \\
\left.(\mathrm{ZrPyrP})^{100}, 238\right)\end{array}$} & $\mathrm{P} / \mathrm{Zr}=2.0$ & $5 \mathrm{meq} / \mathrm{g}$ & \\
\hline & $\mathrm{P} / \mathrm{Zr}=2.5 \sim 2.8$ & & $\mathrm{Cu}(\mathrm{II})>\mathrm{Ni}>\mathrm{Ca}>\mathrm{Na} \gg \mathrm{Fe}(\mathrm{III})>\mathrm{Mg}^{238}$ \\
\hline Zirconium hypophosphate ${ }^{171}$ ) & $\mathrm{P} / \mathrm{Zr}=1.75$ & & $\begin{array}{l}\mathrm{Sn}(\mathrm{II}), \mathrm{Pb}, \mathrm{Fe}(\mathrm{III})>\mathrm{La}, \mathrm{Ga}, \mathrm{Y}, \mathrm{In}, \mathrm{Cs}> \\
\mathrm{Cu}(\mathrm{II}), \mathrm{Co}(\mathrm{II}), \mathrm{Fe}(\mathrm{II}), \mathrm{Ca}, \mathrm{Zn}, \mathrm{Ni}(\mathrm{II}), \\
\mathrm{Ba}, \mathrm{Sr}, \mathrm{Hg} \text { (II) }(0.5 M \text { HCl) }\end{array}$ \\
\hline \multicolumn{2}{|c|}{ Zirconium phthalophosphate $(\mathrm{ZrPhP})^{67)}$} & $4.81 \mathrm{meq} / \mathrm{g}(\mathrm{pH}=10.8)$ & \\
\hline \multicolumn{2}{|c|}{ Zirconium arsenate $\left.(\mathrm{ZrAs})^{91}, 234\right) 319$ ) } & $\left(0.4 \mathrm{meq}(\mathrm{Li}, \mathrm{Na}) / \mathrm{g}^{91}\right)$ & $\left(\mathrm{Cs}>\mathrm{K}>\mathrm{Na}(\mathrm{pH}=2.3 \sim 3.3)^{91}\right)$ \\
\hline (amorphous) & $\mathrm{As} / \mathrm{Zr}=1.53 \sim 1.96$ & $\left\{\begin{array}{l}(\mathrm{pH}=4) \\
4.2 \mathrm{meq}(\mathrm{Li}, \mathrm{Na}) / \mathrm{g} \\
(\mathrm{pH}=6)\end{array}\right.$ & $\left\{\begin{array}{c}(0.1 \mathrm{MCl}+\mathrm{MOH}) \\
\mathrm{Na}>\mathrm{K}>\mathrm{Cs}(\mathrm{pH}=3.8 \sim 4.65) \\
(0.1 \mathrm{MCl}+\mathrm{MOH})\end{array}\right.$ \\
\hline$(\text { crystalline })^{214)}$ & $\mathrm{Zr}\left(\mathrm{HPO}_{4}\right)_{2} \cdot \mathrm{H}_{2} \mathrm{O}$ & $\left\{\begin{array}{c}2.4 \mathrm{meq}(\mathrm{Li}, \mathrm{Na}) / \mathrm{g} \\
(\mathrm{pH}=4) \\
5 \mathrm{meq}(\mathrm{Li}, \mathrm{Na}) / \mathrm{g} \\
(\mathrm{pH}=6)\end{array}\right.$ & $\begin{aligned} \mathrm{Cs}>\mathrm{Rb}>\mathrm{Li}>\mathrm{Na}>\mathrm{K} \\
(0.1 M \mathrm{MOH}+\mathrm{MCl})\end{aligned}$ \\
\hline \multicolumn{4}{|l|}{ Zirconium antimonate $(\mathrm{V})(\mathrm{ZrSb})$} \\
\hline \multirow[t]{2}{*}{ (amorphous) } & $\left.\mathrm{Zr} / \mathrm{Sb}=1 \sim 2^{4}\right)$ & $\left\{\begin{array}{l}\left.0.6 \mathrm{meq}(\mathrm{K}) / \mathrm{g}^{4}\right)(\mathrm{KCl} \text { column }) \\
1.4 \sim 1.6 \mathrm{meq}(\mathrm{K}) / \mathrm{g}(\mathrm{pH}=12)\end{array}\right.$ & Cs, $\mathrm{K}>\mathrm{Na}>\mathrm{Li}^{4}$ \\
\hline & & $0.5 \mathrm{meq}(\mathrm{Cs}) \mathrm{g}^{240)}(\mathrm{pH}=3)$ & $\left.\left.\mathrm{Na}>\mathrm{K}>\mathrm{NH}_{4}>\mathrm{Rb}>\mathrm{Cs}>\mathrm{Li}_{112}\right) 240\right)$ \\
\hline \multicolumn{4}{|c|}{ Zirconium molybdate $(\mathrm{ZrMo})^{105) 340)}$} \\
\hline \multirow[t]{2}{*}{ (amorphous) } & $\mathrm{Zr} / \mathrm{Mo}=0.5 \sim 2.0$ & $2.18 \sim 2.34 \mathrm{meq}(\mathrm{K}) \mathrm{g}$ & \\
\hline & & $\begin{array}{l}0.18 \mathrm{meq} / \mathrm{g} \\
\text { (electron exchange capacity) }\end{array}$ & \\
\hline (microcrystalline) ${ }^{82)}$ & $\mathrm{ZrMo}_{2} \mathrm{O}_{7}(\mathrm{OH})_{2}\left(\mathrm{H}_{2} \mathrm{O}\right)_{2}$ & $\begin{array}{l}8.6 \mathrm{meq}(\mathrm{Na}) / \mathrm{g} \\
\text { (neutralization capacity) }\end{array}$ & \\
\hline $\begin{array}{l}\text { Zirconium tungstate } \\
\left.(\mathrm{ZrW})^{230}>340\right)\end{array}$ & $\mathrm{Zr} / \mathrm{W}=0.44$ & $\begin{array}{l}0.26 \mathrm{meq} / \mathrm{g} \\
\quad \text { (electron exchange capacity) }\end{array}$ & $\mathrm{Cs}>\mathrm{Rb}>\mathrm{K}>\mathrm{Na}>\mathrm{Li}^{187)}$ \\
\hline \multicolumn{2}{|l|}{ Zirconium tellurate $(\mathrm{ZrTe})^{308}$. } & & \\
\hline (amorphous) & & $2.8 \mathrm{meq}(\mathrm{Li}, \mathrm{Na}) / \mathrm{g}$ & $\mathrm{Cs}>\mathrm{Rb}>\mathrm{K} \gg \mathrm{Na} ; \mathrm{Ba}>\mathrm{Ca}>\mathrm{Sr}$ \\
\hline \multicolumn{2}{|c|}{ (crystalline) $\mathrm{Zr}\left(\mathrm{H}_{2} \mathrm{TeO}_{6}\right) \cdot 4 \mathrm{H}_{2} \mathrm{O}^{276 / 343)}$} & $-2.8 \mathrm{meq} / \mathrm{g}(\mathrm{pH}=2.5 \sim 12)$ & \\
\hline \multicolumn{2}{|c|}{ Zirconium oxalate $(\mathrm{ZrOx})^{201}, \quad \mathrm{ZrO}(\mathrm{OH}) \mathrm{C}_{2} \mathrm{O}_{4} \mathrm{H}$} & & $\mathrm{Na}>\mathrm{K}=\mathrm{Rb}=\mathrm{Cs}$ (gel-like) \\
\hline (gel-like and crystalline) & & & $\mathrm{K}>\mathrm{Rb}>\mathrm{Cs}>\mathrm{Na}$ (crystalline) \\
\hline \multicolumn{4}{|l|}{ Titanium based } \\
\hline \multicolumn{4}{|l|}{ Titanium phosphate (TiP) } \\
\hline \multirow[t]{4}{*}{ (amorphous) } & \multicolumn{2}{|c|}{$\mathrm{P} / \mathrm{Ti}=0.6 \sim 2.016,27,50) 107,241,319) 340)$} & \\
\hline & $\left.\mathrm{TiH}_{2}\left(\mathrm{PO}_{4}\right)_{2} \cdot 4 \mathrm{H}_{2} \mathrm{O}^{107}\right)$ & $\sim 7 \mathrm{meq} / \mathrm{g}^{16)}$ & \\
\hline & $\mathrm{Ti}_{3}\left(\mathrm{PO}_{4}\right)_{4}{ }^{107)}$ & & \\
\hline & \multicolumn{3}{|c|}{ (granular amorphous) } \\
\hline (crystalline) & $\left.\mathrm{Ti}\left(\mathrm{HPO}_{4}\right)_{2} \cdot \mathrm{H}_{2} \mathrm{O}^{16}\right) 199>214$ & 1) $\left.7.15 \mathrm{meq}\left(\mathrm{Na}^{+}\right) / \mathrm{g}^{16}\right) \quad(\mathrm{pH}=7)$ & \\
\hline \multicolumn{4}{|l|}{ Titdnium arsenate (TiAs) } \\
\hline \multirow[t]{2}{*}{ (amorphous) } & $\mathrm{As} / \mathrm{Ti}=0.9 \sim 1.1$ & $\left.2.6 \mathrm{meq} \mathrm{Na}^{+} / \mathrm{g}^{33}\right) \quad(\mathrm{pH}=5)$ & \\
\hline & $\left.\mathrm{Ti}\left(\mathrm{HAsO}_{4}\right)_{2} \cdot 2.5 \mathrm{H}_{2} \mathrm{O}^{263}\right)$ & $1.05 \mathrm{meq} \mathrm{K}^{+} / \mathrm{g}^{263)}$ & $\underset{\left.\mathrm{Co}^{263}\right)}{\mathrm{Ba}>\mathrm{Pb}>\mathrm{Cu}>\mathrm{Cd}>\mathrm{Sr}>\mathrm{Ga}>\mathrm{Zn}>\mathrm{Mn}>\mathrm{Ni}>}$ \\
\hline \multirow{4}{*}{$i$} & $\mathrm{As} / \mathrm{Ti}=1.8^{275}$ & $0.99 \mathrm{meq} / \mathrm{g}$ & $\mathrm{Pb}>\mathrm{Ni}>\mathrm{Cd}>\mathrm{Hg}^{2+}>\mathrm{Ba}>\mathrm{Sr}>\mathrm{Zn}>\mathrm{Co}^{275}$ \\
\hline & $\mathrm{As} / \mathrm{Ti}=1.7^{271} \mathrm{l}$ & & $\mathrm{Ba}>\mathrm{Sr}>\mathrm{Ca} \quad($ water $)$ \\
\hline & & & $\mathrm{Fe}(\mathrm{III})>\mathrm{Ni}>\mathrm{V}(\mathrm{IV})>\mathrm{Zn}>\mathrm{Co}$ \\
\hline & & & $\mathrm{Mn}>\mathrm{Cu} \quad($ water $)$ \\
\hline \multirow[t]{2}{*}{ (crystalline) $^{33}$ ) } & $\mathrm{Ti}\left(\mathrm{HAsO}_{4}\right)_{2} \cdot \mathrm{H}_{2} \mathrm{O}$ & $5.8 \mathrm{meq} / \mathrm{g}$ (total capacity) ${ }^{33)}$ & \\
\hline & & $2.6 \mathrm{meq} \mathrm{Na}^{+} / \mathrm{g}(\mathrm{pH}=5)$ & \\
\hline Titanium antimonate (TiSb) & & & \\
\hline (amorphous) 259$) 260)$ & $\mathrm{Sb} / \mathrm{Ti}=1.0 \sim 1.2$ & $0.5 \sim 0.7 \mathrm{meq} / \mathrm{g}$ & $\mathrm{Pb}>\mathrm{Ba}=\mathrm{Ca}>\mathrm{Cu}>\mathrm{Cd}>\mathrm{Ni}>7 . \mathrm{n}$ \\
\hline & & & $\mathrm{Mn}>\mathrm{Sr}>\mathrm{Hg}\left(\right.$ from sample I) ${ }^{259)}$ \\
\hline & $\left.\mathrm{Sb} / \mathrm{Ti}=1.4^{256}\right)$ & $0.77 \mathrm{meq} / \mathrm{g}^{256)}$ & \\
\hline & $\left.\mathrm{Sb} / \mathrm{Ti}=1^{342}\right)$ & $0.5 \mathrm{meq} / \mathrm{g}$ & $\begin{array}{c}\mathrm{Ba}>\mathrm{Zn}>\mathrm{Cd}>\mathrm{Pb}>\mathrm{Sr}>\mathrm{Co}>\mathrm{UO}_{2}{ }^{2+}>\mathrm{Ca}> \\
\mathrm{Ni}>\mathrm{Hg}(\text { from sample G) }\end{array}$ \\
\hline
\end{tabular}




\begin{tabular}{|c|c|c|c|}
\hline Exchanger & Composition & Capacity & Selectivity series \\
\hline & $\mathrm{Sb} / \mathrm{Ti}=1.0 \sim 1.10^{130)}$ & $0.93 \sim 1.8 \mathrm{meq}\left(\mathrm{K}^{+}\right) / \mathrm{g}$ & $\mathrm{Ag}>\mathrm{Hg}>\mathrm{Pb}$ \\
\hline $\begin{array}{l}\text { Titanium molybdate (TiMO) } \\
\text { (amorphous) } \\
\text { (a66) }\end{array}$ & $\mathrm{Mo} / \mathrm{Ti}=0.5 \sim 2.0$ & $\begin{array}{l}0.8 \sim 1.6 \mathrm{meq} / \mathrm{g} \\
1.08 \mathrm{meq} / \mathrm{g}^{256}\end{array}$ & $\left\{\begin{array}{l}\mathrm{Pb}>\mathrm{Sr}>\mathrm{Mg} \\
\mathrm{Ba}>\mathrm{Ca}>\mathrm{Cu}>\mathrm{Cd}>\mathrm{Zn}\end{array}\right.$ \\
\hline $\begin{array}{l}\text { Titanium tungstate (TiW) } \\
\text { (amorphous) }\end{array}$ & $\begin{array}{l}\mathrm{W} / \mathrm{Ti}=1.1^{275} \\
\mathrm{Ti} / \mathrm{W}=2^{248} \\
\mathrm{~W} / \mathrm{Ti}=1 \sim 2^{250}\end{array}$ & $\begin{array}{l}0.58 \mathrm{meq} / \mathrm{g}^{275)} \\
0.42 \sim 0.76 \mathrm{meq} / \mathrm{g}^{248)} \\
0.2(\mathrm{Li}) \sim 1.0(\mathrm{Cs}) \mathrm{meq} / \mathrm{g}\end{array}$ & $\begin{array}{l}\mathrm{Pb}>\mathrm{Mg}>\mathrm{Ga}^{3+}>\mathrm{Sr}^{248} \\
\mathrm{~K}>\mathrm{Na}>\mathrm{Li} \\
\mathrm{Ba}>\mathrm{Sr}>\mathrm{Ca}>\mathrm{Mg}\end{array}$ \\
\hline Titanium selenite(TiSe) 257,275$)$ & $\begin{array}{l}\mathrm{Se} / \mathrm{Ti}=1.2^{275} \\
\left.\mathrm{Se} / \mathrm{Ti}=0.2 \sim 1.39^{257}\right)\end{array}$ & $\begin{array}{l}0.58 \mathrm{meq} / \mathrm{g} \\
0.45 \sim 0.78 \mathrm{meq} / \mathrm{g}\end{array}$ & $\left\{\begin{array}{l}\mathrm{K}>\mathrm{Na}>\mathrm{Li} \quad(\mathrm{pH}=3) \\
\mathrm{Li}>\mathrm{Na}>\mathrm{K} \quad(\mathrm{pH}=8) \\
\mathrm{Li}=\mathrm{Na}>\mathrm{K}(\mathrm{pH}=12)\end{array}\right.$ \\
\hline Titanium vanadate $(\mathrm{TiV})^{273)}$ & $\begin{array}{l}\mathrm{V} / \mathrm{Ti}=4 \\
{\left[\mathrm{Ti}_{3}\left(\mathrm{~V}_{3} \mathrm{O}_{9} \mathrm{I} \cdot 5 \mathrm{H}_{2} \mathrm{O}\right)_{4}\right.} \\
\left.\quad 13 \mathrm{H}_{2} \mathrm{O}\right]\end{array}$ & 0.72 meq $\mathrm{K}^{+} / \mathrm{g}(\mathrm{pH}=6 \sim 7)$ & $\mathrm{Ba}>\mathrm{Sr}>\mathrm{Ca}>\mathrm{Mg}$ \\
\hline $\begin{array}{l}\text { Titanium phosphate silicate }{ }^{219)} \\
\text { (gel) }\end{array}$ & & $0.06 \mathrm{meq} / \mathrm{g}(0.1 \mathrm{M} \mathrm{CsOH})$ & \\
\hline $\begin{array}{l}\text { Thorium based } \\
\text { Thorium phosphate }(\mathrm{ThP})^{18} \\
\text { (crystalline) }\end{array}$ & $\mathrm{Th}\left(\mathrm{HPO}_{4}\right)_{2} \cdot 3 \mathrm{H}_{2} \mathrm{O}$ & $3.7 \mathrm{meq}(\mathrm{Na}) / \mathrm{g}$ & \\
\hline $\begin{array}{l}\text { Thorium arsenate } \\
\quad \text { (crystalline) } \\
\text { Thorium molybdate } \\
\text { 254) }\end{array}$ & $\mathrm{Th}\left(\mathrm{HAsO}_{4}\right) \cdot \mathrm{H}_{2} \mathrm{O}$ & $\begin{array}{l}3.55 \mathrm{meq}(\mathrm{Li}) / \mathrm{g}(\mathrm{pH}=9.5) \\
0.54 \sim 0.64 \mathrm{meq}(\mathrm{Na}, \mathrm{K}, \mathrm{Ba}) / \mathrm{g}\end{array}$ & $\begin{array}{l}\text { selective adsorption for } \mathrm{Li} \\
\mathrm{In}>\mathrm{Ga}>\mathrm{Al}, \mathrm{Ba}>\mathrm{Ni}>\mathrm{Cd}, \mathrm{Hg}>\mathrm{Sr}>\mathrm{La}, \mathrm{Cu}, \mathrm{Mg}\end{array}$ \\
\hline $\begin{array}{l}\text { Cerium based } \\
\text { Cerium phosphate }(\mathrm{CeP})^{117) 172}\end{array}$ & $1 7 8 \longdiv { 1 7 9 , 2 0 4 ) }$ & & \\
\hline (amorphous) & $\left\{\begin{array}{l}\mathrm{P} / \mathrm{Ce}=1.03 \sim 1.95 \\
(\mathrm{Ce}-\mathrm{O}-\mathrm{Ce})_{2}\left(\mathrm{P}_{2} \mathrm{O}_{7}\right)_{3}\end{array}\right\}$ & $\left\{\begin{array}{l}0.41 \sim 0.56 \mathrm{meq}(\mathrm{Na}, \mathrm{K}) / \mathrm{g} \\
\quad(\mathrm{pH}=1.51) \\
0.63 \sim 0.89 \mathrm{meq}(\mathrm{Na}, \mathrm{K}) / \mathrm{g} \\
\quad(\mathrm{pH}=2.56)\end{array}\right\}$ & $\mathrm{Cs}>\mathrm{Ag}>\mathrm{Na}$ (macro and trace amount) ${ }^{178)}$ \\
\hline $\begin{array}{l}\text { (fibrous crystalline) } 23) 24 \text { ) } \\
26331)\end{array}$ & $\begin{array}{l}\left.\mathrm{CeIV}(\mathrm{OH})_{8}\left(\mathrm{H}_{2} \mathrm{PO}_{4}\right)_{4} 204\right) \\
\mathrm{P} / \mathrm{Ce}=1.98\end{array}$ & $\begin{array}{l}0.359 \mathrm{meq} / \mathrm{meq}-\mathrm{P}_{2} \mathrm{O}_{5} \\
5.2 \mathrm{meq} / \mathrm{g}\end{array}$ & $\begin{array}{l}\mathrm{Cs}>\mathrm{Ag}>\mathrm{Na}(\mathrm{TLC}) \\
\mathrm{K}>\mathrm{Na}>\mathrm{Li}\left(1 \mathrm{M} \mathrm{\textrm {HClO } _ { 4 }} \mathrm{TLC}\right) \\
\mathrm{Tl}(\mathrm{I})>\mathrm{Ag}>\mathrm{Ni}\left(1 M \mathrm{HClO}_{4} \mathrm{TLC}\right) \\
\mathrm{Fe}(\mathrm{II})>\mathrm{Eu}(\mathrm{II})>\mathrm{Co}\left(1 M \mathrm{HClO}_{4} \mathrm{TLG}\right)\end{array}$ \\
\hline (micro crystalline) ${ }^{178)}$ & $\mathrm{P} / \mathrm{Ce}=1.91,1.28$ & $\begin{array}{l}0.35 \mathrm{meq}(\mathrm{Na}) / \mathrm{g} \\
0.11 \mathrm{meq}(\mathrm{Cs}) / \mathrm{g}(\mathrm{pH}=1.53) \\
0.61 \mathrm{meq}(\mathrm{Na}) / \mathrm{g} \\
0.21 \mathrm{meq}(\mathrm{Cs}) / \mathrm{g}(\mathrm{pH}=2.55)\end{array}$ & $\begin{array}{l}\mathrm{Ag}>\mathrm{Na}>\mathrm{Cs} \text { (micro amount) } \\
\mathrm{Cs}>\mathrm{Ag}>\mathrm{Na} \text { (micro amount) }\end{array}$ \\
\hline $\begin{array}{l}\text { Cerium phosphate-sulfate } \\
\quad(\mathrm{CePS}) 172) 174)\end{array}$ & $\begin{array}{l}\left(\mathrm{Ce}_{2} \mathrm{O}\right)\left(\mathrm{HPO}_{4}\right)_{3-x}\left(\mathrm{SO}_{4}\right)_{x} \cdot 4 \mathrm{I} \\
\quad(0<x<1)\end{array}$ & $\mathrm{H}_{2} \mathrm{O}$ & $\begin{array}{c}\mathrm{Na}>\mathrm{Ag}>\mathrm{Sr}>\mathrm{Ba}>\mathrm{Cs}>\mathrm{Ca} \\
(\mathrm{Ce}: \mathrm{P}: \mathrm{S}=2: 2: 1)\end{array}$ \\
\hline $\begin{array}{l}\text { Cerium arsenate }(\mathrm{Ce} \Lambda \mathrm{s})^{23} \\
\quad \text { (crystalline) }\end{array}$ & $\mathrm{Ce}\left(\mathrm{HAsO}_{4}\right)_{2} \cdot 2 \mathrm{H}_{2} \mathrm{O}$ & $\begin{array}{l}4.35 \mathrm{meq}(\mathrm{Na}) / \mathrm{g} \\
4.35 \mathrm{meq}(\mathrm{Li}) / \mathrm{g}\end{array}$ & $\begin{array}{l}\mathrm{K}>\mathrm{Na}>\mathrm{Li} \text { low } \mathrm{pH}(0.1 M \mathrm{MCl}+\mathrm{MOH}) \\
\mathrm{Li}>\mathrm{Na}>\mathrm{K} \text { high } \mathrm{pH}(0.1 M \mathrm{MCl}+\mathrm{MOH})\end{array}$ \\
\hline Cerium antimonate $(\mathrm{CeSb})^{127)}$ & $\mathrm{Sb}(\mathrm{V}) / \mathrm{Ce}(\mathrm{IV})=0.30-0.33$ & $1.27 \mathrm{meq}(\mathrm{K}) / \mathrm{g}$ & $\mathrm{Hg}(\mathrm{II})>\mathrm{Cd}$ \\
\hline Cerium tungstate $(\mathrm{CeW})^{27}$ & $\mathrm{~W} / \mathrm{Ce}(\mathrm{IV})=2$ & $0.4 \sim 0.89 \mathrm{meq}(\mathrm{Na}) / \mathrm{g}$ & $\begin{array}{l}\mathrm{Hg}(\mathrm{II})>\mathrm{Tl}(\mathrm{I})>\mathrm{Co}>\mathrm{Tl}(\mathrm{III})>\mathrm{Ag}>\mathrm{Cs}>\mathrm{Cu} \gg \\
\mathrm{Ni}, \mathrm{Zn}>\mathrm{Cd}>\mathrm{Mn}(\mathrm{II})\end{array}$ \\
\hline $\begin{array}{l}\text { Stannic based } \\
\text { Tin(IV) phosphate }(\mathrm{SnP})^{108}\end{array}$ & $\begin{array}{l}\mathrm{SnO}_{2}: \mathrm{P}_{2} \mathrm{O}_{5}: \mathrm{H}_{2} \mathrm{O} \\
\quad=1.0: 0.58: 3.87\end{array}$ & $0.92 \mathrm{meq}(\mathrm{Na}) / \mathrm{g}$ & $\mathrm{Ba}>\mathrm{Sr}>\mathrm{Ca}>\mathrm{Mg} \quad(\mathrm{pH}=2.5)$ \\
\hline $\begin{array}{l}\text { Stanic phosphate } \\
\text { (amorphous) }\end{array}$ & $\left.\mathrm{P} / \mathrm{Sn}=0.344 \sim 1.26^{150}\right)$ & $\begin{array}{l}0.6 \sim 1.26 \mathrm{meq}(\mathrm{Na})^{150)} / \mathrm{g} \\
\quad(\mathrm{NaCl} \text { soln. })\end{array}$ & $\begin{array}{l}\mathrm{Cs}>\mathrm{Rb}>\mathrm{K}>\mathrm{Na}\left(\mathrm{HNO}_{3}\right) \\
\mathrm{Cs}>\mathrm{Zr}>\mathrm{Nb}>\mathrm{Y}>\mathrm{Ce}(\mathrm{III})>\mathrm{Sr} \gg \mathrm{Ru}^{149)} \\
\left.(0.1 M \mathrm{HNO})^{3}\right) \\
\mathrm{Zr}>\mathrm{Nb}>\mathrm{Cs} \gg \mathrm{Ce}(\mathrm{III}), \mathrm{Y}, \mathrm{Sr}, \mathrm{Ce}(\mathrm{IV}), \mathrm{Rb}^{149} \\
(1.0 M \mathrm{HNO} 3) \\
\mathrm{Fe}(\mathrm{II})>\mathrm{Fe}(\mathrm{III}), \mathrm{UO}_{2}^{2+}, \mathrm{Rb} \gg \mathrm{Co}, \mathrm{Cu}(\mathrm{II}) \\
\left.\mathrm{Ni}^{264}\right)\left(1.0 \mathrm{HNO}_{3}\right)\end{array}$ \\
\hline & $\begin{array}{l}\mathrm{Sn}: \mathrm{P}: \mathrm{H}_{2} \mathrm{O}=1: 1.06: 3.26 \\
\left.\mathrm{P} / \mathrm{Sn}=1.25 \sim 1.50^{264}\right)\end{array}$ & $\begin{array}{c}0.92 \mathrm{meq}(\mathrm{Na}) / \mathrm{g}^{264)} \\
1.22 \sim 1.44 \mathrm{meq} / \mathrm{g}\end{array}$ & $\begin{array}{l}\mathrm{Cu}>\mathrm{Zn}>\mathrm{Ni}>\mathrm{Co}^{241} \\
\left.\mathrm{Cs}>\mathrm{Rb}>\mathrm{K}>\mathrm{Na}>\mathrm{Li}^{264}\right) \quad \text { (trace) }\end{array}$ \\
\hline (crystalline) & $\mathrm{Sn}\left(\mathrm{HPO}_{4}\right)_{2} \cdot \mathrm{H}_{2} \mathrm{O}$ & $7.9 \mathrm{meq}(\mathrm{Li}) / \mathrm{g}$ & $\begin{array}{l}\mathrm{K}>\mathrm{Na}>\mathrm{Li}>\mathrm{Cs}(\mathrm{pH}=4.0,0.1 M) \\
\mathrm{Li}>\mathrm{Na}-\mathrm{K}>\mathrm{Cs}(\mathrm{pH}=7.0,0.1 M)\end{array}$ \\
\hline $\begin{array}{l}\text { Stannic arsenate (SnAs) } \\
\text { (amorphous) }\end{array}$ & $\mathrm{As} / \mathrm{Sn}=0.5$ & $\begin{array}{l}2.25 \text { meq }(\mathrm{Cu}) / \mathrm{g} \text { (column) } \\
\text { Batch } 1.22(\mathrm{Li}), 1.26(\mathrm{Na}) \\
\\
1.35(\mathrm{~K})\end{array}$ & 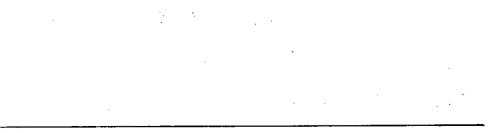 \\
\hline
\end{tabular}




\begin{tabular}{|c|c|c|c|}
\hline Exchanger & Composition & Capacity & Selectivity series \\
\hline & $\begin{array}{l}\mathrm{SnO}_{2}: \mathrm{As}_{2} \mathrm{O}_{5}: \mathrm{H}_{2} \mathrm{O} \\
\quad=1: 0.25: 3.26^{108}\end{array}$ & $\left.0.75 \mathrm{meq}(\mathrm{Na}) / \mathrm{g}^{108}\right)$ & $\left.\mathrm{Cu}>\mathrm{Zn}>\mathrm{Co}>\mathrm{Ni}>\mathrm{Mn}^{31}\right)(\mathrm{pH}=2.5)$ \\
\hline \multirow{2}{*}{ (crystalline) } & $\mathrm{Sn}: \mathrm{As}=0.33^{267}$ & & $\mathrm{Cu}>\mathrm{Co}>\mathrm{Zn}>\mathrm{Ni}^{267}$ \\
\hline & $\left.\left.\mathrm{Sn}\left(\mathrm{HAsO}_{4}\right)_{2} \cdot \mathrm{H}_{2} \mathrm{O}^{97}\right) 267\right)$ & & \\
\hline \multicolumn{4}{|c|}{ Stannic antimonate $(\mathrm{SnSb})^{4}, 267$ ) } \\
\hline \multirow[t]{2}{*}{ (glass-like) } & $\left.\mathrm{Sn} / \mathrm{Sn}=1: 4 \sim 2: 1^{4}\right)$ & $1.3 \mathrm{meq}(\mathrm{K}) / \mathrm{g}(\mathrm{pH}=7)$ & $\left.\mathrm{Cs}>\mathrm{Rb}>\mathrm{K}>\mathrm{Na}, \mathrm{Li}^{4}\right)$ \\
\hline & $\mathrm{Sb} / \mathrm{Sn}=0.99 \sim 1.4^{267}$ & $0.75 \sim 0.95 \mathrm{meq}(\mathrm{K}) / \mathrm{g}$ & $\begin{aligned} \mathrm{Cd} & \gg \mathrm{Ba}, \mathrm{Sr}>\mathrm{Zn}, \mathrm{Hg}(\mathrm{II})>\mathrm{Co}>\mathrm{Mn}>\mathrm{Mg}> \\
\mathrm{Cu} & >\mathrm{Ca}^{267)}(\mathrm{pH}=1)\end{aligned}$ \\
\hline \multicolumn{2}{|c|}{ Stannic molybdate $(\mathrm{SbMo})^{252,269,270)}$} & & . \\
\hline \multirow[t]{2}{*}{ (amorphous) } & $\mathrm{Mo} / \mathrm{Sn}(\mathrm{IV})=1269$ & 1.0 meq $(\mathrm{Na}$ or $\mathrm{Ba}) / \mathrm{g}$ & $\mathrm{Pb} 11$ divalent cation 269,270 ) \\
\hline & $\mathrm{Sn} / \mathrm{Mo}=1.7 \sim 1.99262)$ & $0.54 \sim 0.73 \mathrm{meq} / \mathrm{g}$ & \\
\hline $\begin{array}{l}\text { Stannic tungstate }(\mathrm{SnW})^{272)} \\
\quad \text { (granules) }\end{array}$ & $\mathrm{Sn} / \mathrm{W}=1.3$ & $\sim 0.58 \mathrm{meq} / \mathrm{g})$ & $\begin{array}{l}\mathrm{Co}>\mathrm{Ba}>\mathrm{Pb}>\mathrm{Ni}>\mathrm{Cu}, \mathrm{Mn}, \mathrm{Sr}>\mathrm{Mg}>\mathrm{Cd}>\mathrm{Zn} \\
\text { (water) }\end{array}$ \\
\hline \multicolumn{4}{|l|}{ Stannic selenite $(\mathrm{SnSe})^{264)}$} \\
\hline \multirow{3}{*}{ (amorphous) } & $\left(\mathrm{SnO}_{4}\right) \cdot(\mathrm{OH})_{2}$ & $0.75 \mathrm{meq}(\mathrm{Na}) / \mathrm{g}$ & $\mathrm{La}>\mathrm{Ce}>\mathrm{Y}>\mathrm{Al}>\mathrm{Ga}>\mathrm{In}$ \\
\hline & $\left.\left(\mathrm{SeO}_{3}\right)_{3} \cdot 6 \mathrm{H}_{2} \mathrm{O}\right)$ & $0.60 \mathrm{meb}(\mathrm{Cs}) / \mathrm{g}$ & $\mathrm{Ba}>\mathrm{S}>\mathrm{Ga}>\mathrm{Mg}$ \\
\hline & & & $\mathrm{Pb}, \mathrm{Fe}(\mathrm{III}), \mathrm{Pr}, \mathrm{In}, \mathrm{Sr} \gg 25$ metal ions 257 ) \\
\hline Stannous polyphosphate ${ }^{64}$ ) & & $\begin{array}{l}0.44 \sim 0.59 \mathrm{meq} / \mathrm{g} \\
\quad \text { (electron exchange capacity) }\end{array}$ & \\
\hline \multicolumn{4}{|l|}{ Chromium based } \\
\hline \multirow{2}{*}{$\begin{array}{l}\text { Chromium phosphate } \\
\left.\left.(\mathrm{CrP})^{300} 307,342\right) 344\right)\end{array}$} & $\mathrm{P} / \mathrm{Cr}=0.6 \sim 1.0$ & $5.9 \mathrm{meq} / \mathrm{g}$ & $\mathrm{Na}>\mathrm{K} \gg \mathrm{Rb}>\mathrm{Cs}(\mathrm{H} \text { form })^{342}$ ) \\
\hline & & & $\mathrm{Na}>\mathrm{K}>\mathrm{Cs} \gg \mathrm{Rb}\left(\mathrm{NH}_{4}\right.$ form $)$ \\
\hline \multicolumn{4}{|c|}{ Ghromium tripoyphosphate (GrTriPP) $\left.{ }^{61}, 62\right)$} \\
\hline \multirow[t]{4}{*}{ (green glassy) } & $\mathrm{P} / \mathrm{Cr}=2.48$ & $2.5 \mathrm{meq}(\mathrm{K}, \mathrm{Ca}) / \mathrm{g}(\mathrm{pH}=7)$ & $\begin{array}{l}\mathrm{Cs}>\mathrm{Rb}>\mathrm{K}>\mathrm{Na}>\mathrm{H} \gg \text { many polyvalent } \\
\text { metal ions }\end{array}$ \\
\hline & $\left.\mathrm{Cr}_{5}\left(\mathrm{P}_{3} \mathrm{O}_{10}\right)_{3} \cdot x \mathrm{H}_{2} \mathrm{O}^{61}\right)$ & $\because$ & \\
\hline & $\left.\mathrm{H}_{2} \mathrm{CrP}_{3} \mathrm{O}_{10} \cdot 2 \mathrm{H}_{2} \mathrm{O}^{49}\right)$ & & \\
\hline & $\left.\mathrm{P} / \mathrm{Cr}=3.0^{13}\right)$ & $\begin{array}{l}\left.1.39 \sim 1.57 \mathrm{meq}(\mathrm{Na}) / \mathrm{g}^{13}\right) \\
(\mathrm{pH}=4.1)\end{array}$ & $\mathrm{Ba} \gg \mathrm{Cs}>\mathrm{Rb}>\mathrm{Na}>\mathrm{Zn}>\mathrm{Co}^{13}$ \\
\hline \multicolumn{4}{|l|}{ Chromium arsenate 258 ) } \\
\hline (amorphous) & $\mathrm{As} / \mathrm{Cr}=1.98$ & $0.65 \mathrm{meq}(\mathrm{K}) / \mathrm{g}(\mathrm{pH}=6 \sim 7)$ & $\begin{array}{l}\mathrm{Rb}, \mathrm{VO}^{2+}, \mathrm{Ga}, \mathrm{In}, \mathrm{Nd}, \mathrm{Fe}(\mathrm{III}), \mathrm{Th}, \mathrm{Zr}, \mathrm{Hf}, \\
\mathrm{Sc} \gg \text { other } 16 \text { metal ions }\end{array}$ \\
\hline \multicolumn{4}{|l|}{ Other acid salt } \\
\hline \multicolumn{4}{|l|}{ Tantalum phosphate 226$) 227$ ) } \\
\hline (amorphous) & $\mathrm{TaO}_{2}\left(\mathrm{H}_{2} \mathrm{PO}_{4}\right)_{0.88} \cdot 6 \mathrm{H}_{2} \mathrm{O}$ & & $\begin{array}{l}\mathrm{Cs}>\mathrm{Rb}>\mathrm{K} \gg \mathrm{Na} \\
\mathrm{Tl}>\mathrm{Ag}>\mathrm{Cs}>\mathrm{Rb}>\mathrm{K}>\mathrm{NH}>\mathrm{Na}>\mathrm{Li}\end{array}$ \\
\hline \multirow[t]{3}{*}{ Tantalum antimonate ${ }^{275}$ ) } & $\mathrm{Sb} / \mathrm{Ta}=1.3$ & $1.0 \mathrm{meq} / \mathrm{g}$ & $\begin{array}{l}\mathrm{II}>\mathrm{Ag}>\mathrm{Cs}>\mathrm{Kb}>\mathrm{K}>\mathrm{NH}_{4}>\mathrm{Na}>\mathrm{Li} \\
\mathrm{Ba}>\mathrm{Pb}>\mathrm{Sr}>\mathrm{Ca}>\mathrm{Ni}>\mathrm{Cd}>\mathrm{Cu}>\mathrm{Co}>\mathrm{Zn}>\end{array}$ \\
\hline & & & $\begin{array}{l}\mathrm{Ba}>\mathrm{Pb}>\mathrm{Sr}>\mathrm{Ca}>\mathrm{Ni}>\mathrm{Cd}>\mathrm{Cu}>\mathrm{Co}>\mathrm{Zn}> \\
\mathrm{Mg}>\mathrm{Mn}(\mathrm{II})\end{array}$ \\
\hline & & & $\mathrm{La}>\mathrm{Ce}>\mathrm{Pr}>\mathrm{Nd}>\mathrm{Sm}>\mathrm{Eu}>\mathrm{Y}>\mathrm{Sc}>\mathrm{Al}$ \\
\hline \multicolumn{4}{|c|}{ Aluminum and ferric triphosphate (AlFetriP) ${ }^{169}$ ) } \\
\hline & $\mathrm{M} / \mathrm{P}=0.5 \sim 0.66$ & $3.62 \sim 5.37 \mathrm{meq} / \mathrm{g}(\mathrm{pH} \fallingdotseq 11)$ & \\
\hline \multirow[t]{2}{*}{ Aluminum vanadate $\left.(\mathrm{AlV})^{63}\right)$} & $\left(\mathrm{Al}_{2} \mathrm{O}_{3}\right)_{n}\left(\mathrm{~V}_{2} \mathrm{O}_{5}\right)_{m}$ & & \\
\hline & $n / m=2.0 \sim 0.5, \quad m=2 \sim 10$ & & \\
\hline Ferric pyro phosphate $\left.{ }^{63}\right)$ & $\mathrm{Fe}_{4}\left(\mathrm{P}_{2} \mathrm{O}_{7}\right)_{3}$ & & \\
\hline \multicolumn{4}{|c|}{ Phosphoantimonic (V) $\left.\operatorname{acid}^{153}\right) \sim 157$ ) } \\
\hline (glassy) & $\mathrm{P} / \mathrm{Sb}=0.5$ & $1.5 \sim 2.0 \mathrm{meq} / \mathrm{g}(\mathrm{pH}=7)$ & $\mathrm{Cs}>\mathrm{Rb}>\mathrm{K}>\mathrm{Na}>\mathrm{Li}$ \\
\hline$(\text { silica gel-support })^{76)}$ & $\mathrm{P} / \mathrm{Sb}=0.5 \sim 1.0$ & & $\begin{array}{l}\mathrm{Na}>\mathrm{Sr}>\mathrm{Ca} \gg \mathrm{Rb}>\mathrm{Eu}, \mathrm{K}>\mathrm{Li} \\
\mathrm{Cs}>\mathrm{Eu}>\mathrm{Rb}>\mathrm{K}>\mathrm{Na}>\mathrm{Sr}\end{array}$ \\
\hline $\begin{array}{l}\text { Lead strontium phosphate } \\
\quad(\mathrm{PbSP})\end{array}$ & $\mathrm{Pb}_{7} \mathrm{Sr}_{3}\left(\mathrm{PO}_{4}\right)_{6}(\mathrm{OH})_{2}$ & & selective adsorption for $\mathrm{F}^{-}$ \\
\hline
\end{tabular}

$=2.0 ， 2.5$ 2.8) の異なったゲル状物として得られる. 吸着順序は Table VI に示したように $\mathrm{Cu}^{2+}>\mathrm{Ni}^{2+}>$ $\mathrm{Ca}^{2+}>\mathrm{Fe}^{3+}>\mathrm{Mg}^{2+}$ を示し $\mathrm{Fe}^{3+}$ の吸着性が非常に低い のが特徵である.プルトニウムに対して選択的に吸着す る306). しかしこれはイオン交換機構ではない.

2.2.4 各種ポリリン酸ジルコニゥムジルコニウム 塩溶液と種々の重合度をもつポリリン酸ナトリウム溶液 から得られる ${ }^{65) 66)}$. 交換容量は出発物質のポリリン酸の
重合度の増大とともに增大する.しかしながら重合度が 増大すると交換速度が小さくなる. このアンモニア形は アルカリ金属に対して選択性があり，それらの分離や精 製に利用することができる211)217).

\subsection{5 リン酸-ケイ酸ジルコニゥム $(\mathrm{ZrPSi})$ 塩}

化ジコニルとケイ酸ナトリウムの塩酸溶液に $1: 1$ の アンモニア水を加えてケイ酸ジルコニウムが生成する. これを水洗したのち $1 M$ 硝酸と $1 M$ リン酸溶液との混 
合液を加えて数時間放置後水洗し乾燥して得られる221). ジルコニウムとリン酸の添加比によってその組成は変化 する. 交換容量は $6.6 \mathrm{meq} / \mathrm{g}^{52}$ であり, また $70 \sim 80^{\circ} \mathrm{C}$ で乾燥したものの動的交換容量は $\mathrm{Cs}^{+}$について 0.56 $\mathrm{meq} / \mathrm{g}$ および $\mathrm{Na}^{+}$について $2.2 \mathrm{meq} / \mathrm{g}(\mathrm{pH}=7)$ であ った.シリカゲルはおもに一種の binder として作用す ると考えられ，その吸着特性はほとえどもとの $\mathrm{ZrP}$ と 同様であるが特定なイオンに対してより選択性が向上す ることがある．この交換体の特長はプルトニウム(IV) に対して高い選択性をもち，0.5N の硝酸溶液中での $K_{d}$ は $\mathrm{Pu}=250, \mathrm{Cs}=700$ で $0.6 \phi \times 2 \mathrm{~cm}$ のカラムでプ ルトニウムを他の fission product から分離でき, 除染 係数は $0.6 \times 10^{3}$ で活性炭によるガスクロマトグラフィ 一の 30 上りはるかに大きい. Dowex 1-X-8 酸化鉛(IV) および ZrPSi の複合カラムを利用して単純でしかも効 果的なバークリウムの分離に成功している. Fig. 7,8 に 示したようにトランス・プルトニウムや fission element を $\mathrm{ZrPSi}$ カラムに通すと $\mathrm{Pu}^{4+}, \mathrm{Zr}^{4+}$, ニオブ(V) やセ シウムなどは ZrPSi カラムに保持される.さらに第二 カラムの上の部分は $\mathrm{ZrPSi}$ と酸化鉛(IV) の均一に混ざ ったカラムで，バークリウムやセリウムは 4 価に酸化さ れてこの層に吸着される. 他のものは完全にこのカラム を通過する. さらに $2.5 \mathrm{ml}$ の $1 M$ 硝酸で洗浄する.

アメリシウム，キュリウム，カルホルニウムからバーク リウムの分離の係数は $3 \times 10^{3}$ よりも大きい. バークリ ウムは $7 M$ 硝酸で溶離できる. セリウム (IV) は ZrPSi

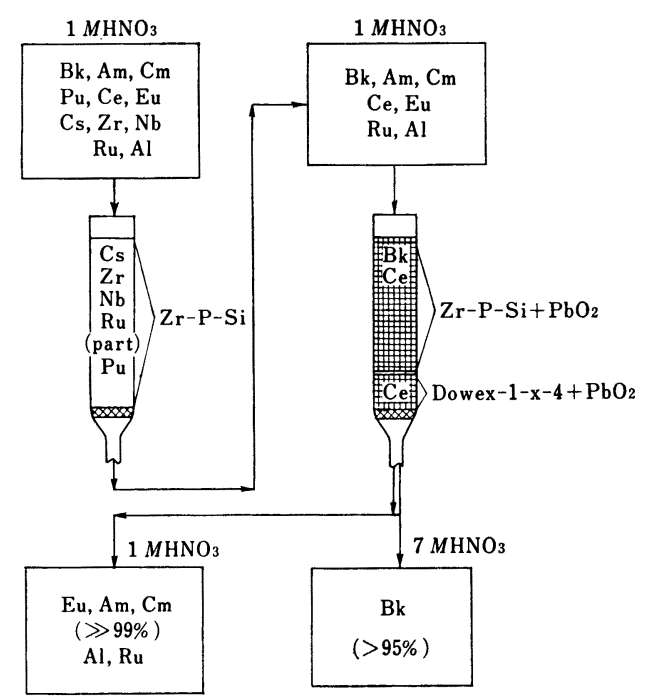

Fig. 7 Scheme of berkelium isolation from transplutonium and fission elements in solution

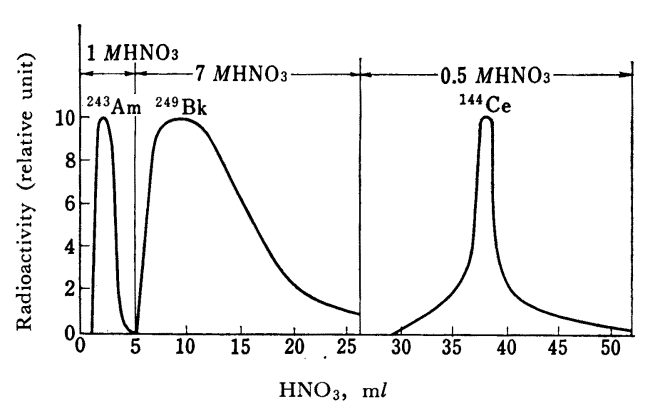

Fig. 8 Elution of ${ }^{241} \mathrm{Am},{ }^{249} \mathrm{Bk}$ and ${ }^{144} \mathrm{Ce}$ from the column containing a mixture of $400 \mathrm{mg}$ Dowex-1-X-4 and 200mg of $\mathrm{PbO}_{2} /$ lower bed/, and a mixture of $500 \mathrm{mg}$ of zirconium phosphate silcate sorbent and $200 \mathrm{mg} \mathrm{PbO}_{2} /$ upper bed/, with nitric acid solutions Rate of passing the solution through the column: $\sim 0.04 \mathrm{~m} l / \mathrm{min}$; Glass colunmn : $0.3 \sim 0.4 \phi \times 10 \mathrm{~cm}$

カラムを通過するが， Dowex-1-X4 と酸化鉛 (IV) の 混合物カラムに硝酸錯体として吸着され $0.5 M$ 硝酸で分 離される.このようにしてルテニウムを除くすべての放 射性不純物から精度および純度よく分離できた． ${ }^{106 R u}$ についてはカラムを通す前に試料を過塩素酸といっしょ に白煙が出るまで加熱し, さらに乾固すると酸化ルテニ ウム(VIII) の形で気化する.

また， ${ }^{239} \mathrm{~Np}(\mathrm{IV})$ とプルトニウム(IV) の分離では 0.5 $M$ 硝酸ではネプッニウム (IV) とプルトニウム (IV) と も ZrPSi カラムによく吸着されるが， $0.05 M$ の濃度に なるように $\mathrm{Fe}\left(\mathrm{NH}_{2} \mathrm{SO}_{3}\right)_{2}-\mathrm{N}_{2} \mathrm{H}_{4} \cdot 2 \mathrm{HCl}$ を加えてプルト ニウム (III) に還元するとプルトニウムの吸着性は小さ いので $0.5 M$ 硝酸で溶離されネプツニウム (IV) はカラ ム内に残る ${ }^{291)}$ ）ネプッニウム (IV) は $8 M$ 硝酸で溶離

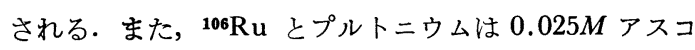
ルビン酸でプルトニウムに還元され $1 M$ 硝酸で溶離さ れた ${ }^{320)}$.

また TiPSi も報告されており，その挙動は TiP に類 似しているが，4 価金属の吸着性はむしろ増大した318).

2.2.6 次リン酸ジルコニゥム 塩化 ジコニルと 次リン酸二水素二ナトリウム溶液を $0.5 N$ 塩酸中で加え ると $\mathrm{P} / \mathrm{Zr}=1.75$ の無定形ゲルが得られる ${ }^{171) 176) 180) .}$ TLC で吸着性を検討した結果, 遷移金属イオンと希土 類元素の群分離に有効である171).

2.2.7 ヒ酸ジルコニゥム(ZrAs) Krus ${ }^{187)}$ やAmphlett ${ }^{38)}$ らによってイオン交換体として挙動することが報 告され，その後, Clearfield ${ }^{91}$ らによって調製法が検討さ れた 2983319). 基本的には $\mathrm{ZrP}$ と同様な交換体と考えて 


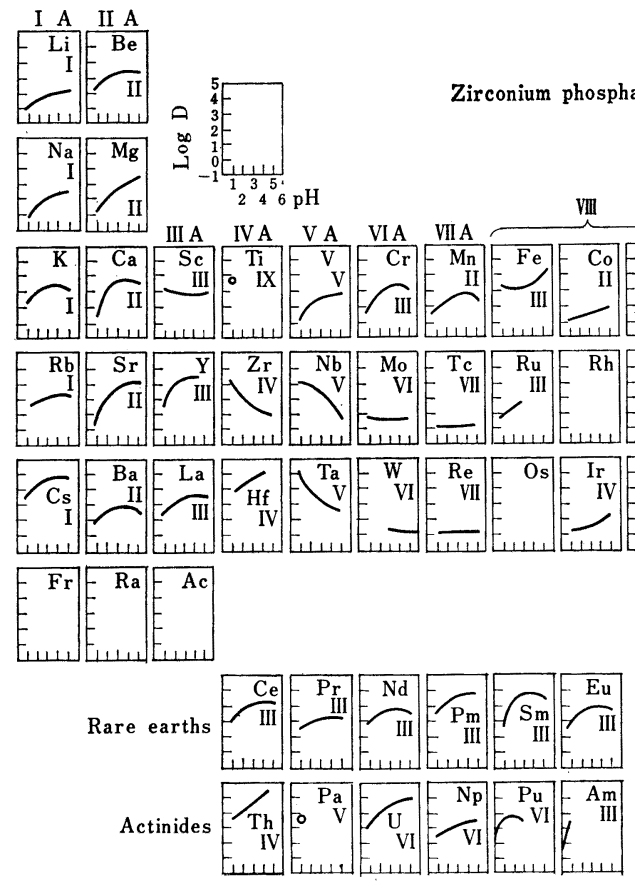

Fig. 9-1 Exchange characteristics of elements on zirconium phosphate

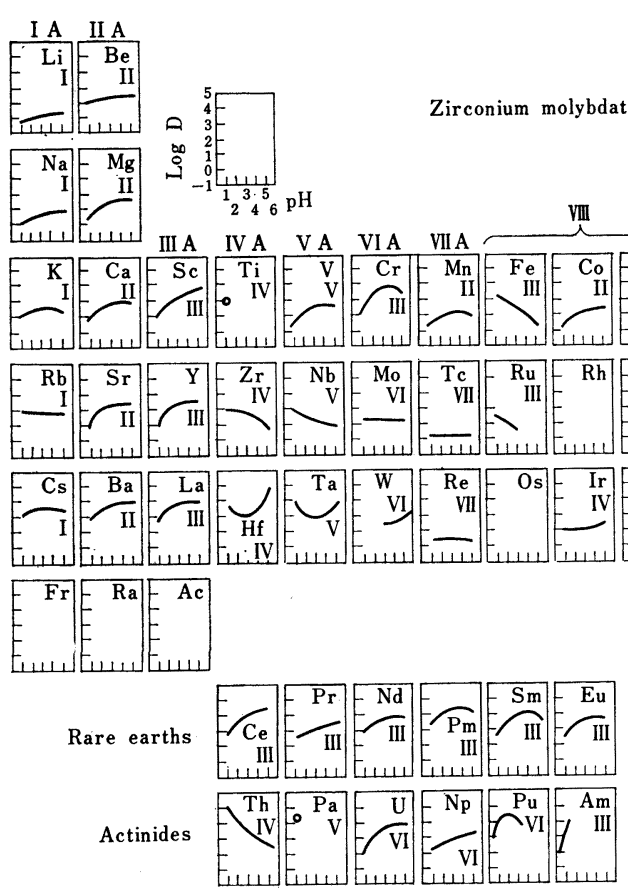

Fig. 9-2 Exchange characteristics of elements on zirconium molybdate 


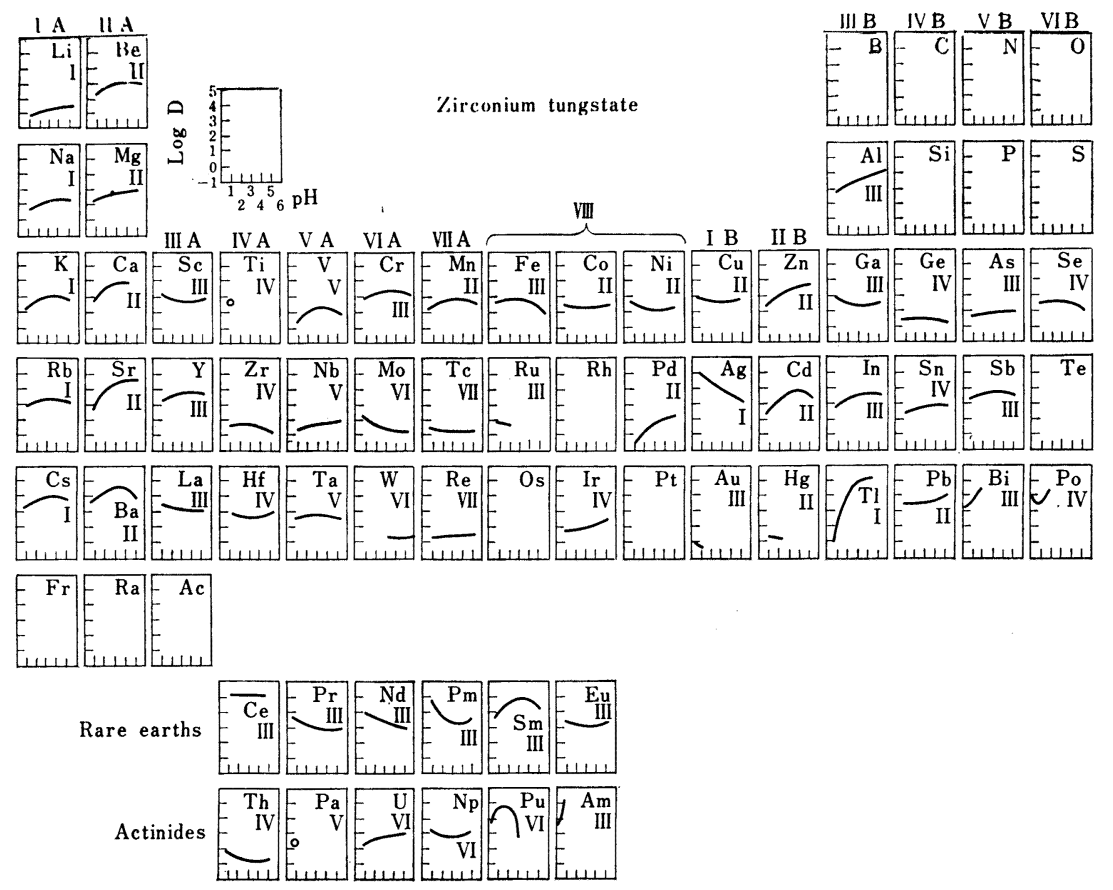

Fig. 9-3 Exchange characteristics of elements on zirconium tungstate

よい. 無定形 $\mathrm{ZrAs}$ は $\mathrm{pH} 2.6$ から $\mathrm{Cs}^{+}>\mathrm{K}+>\mathrm{Na}^{+}$, $\mathrm{pH} 4.5$ から $\mathrm{Na}^{+}>\mathrm{K}^{+}>\mathrm{Cs}^{+}$の吸着順序を示してい る. 特にセシウムに対して選択性があり，アルカリ金属 や多価金属イオンから分離できる298).

2・2・8 アンチモン酸ジルコニゥム $(\mathrm{ZrSb}) \quad$ 酸化ア ンチモン $(\mathrm{V})$ を塩酸に溶解した溶液に填化ジルコニル溶 液を加えて得られる. 吸着順序は $\mathrm{Na}^{+} \gg \mathrm{K}+>\mathrm{NH}^{4+}>$ $\mathrm{Rb}^{+}>\mathrm{Cs}^{+}>\mathrm{Li}^{+}{ }^{+2) 115)}$ ，水素形加ら $\left.\mathrm{Na}^{+}>\mathrm{Rb}^{+}>\mathrm{K}+240\right)$ が報告されている. 著者らはこれらの調製条件では結晶 性アンチモン酸の生成によってその吸着性が現われたも のと考えられ， $\mathrm{ZrSb}$ の吸着順序は $\mathrm{K}^{+}>\mathrm{Na}^{+}>\mathrm{Li}^{+}$で あり， $\mathrm{Li}^{+}$は単に水で溶離できると報告している4).

2.2.9 モリブデン酸 ジルコニウム (ZrMo) 塩化 ジルコニルとモリブデン酸ナトリウムを混ぜたのちアン モニア水で中和するとゲル状物が得られる. 組成 $(\mathrm{Zr} /$ $\mathrm{Mo}=0.5 \sim 2.0)$ は $\mathrm{pH}$ によって連続的に変化し, 交換 容量は $2.18 \mathrm{meq} \mathrm{K}+/ \mathrm{g} ， 2.43 \mathrm{meq} \mathrm{Gs} / \mathrm{g}$ を示した. $\mathrm{Zr} /$ $\mathrm{Mo}=1$ で $1.9 \mathrm{meq} \mathrm{K}+\mathrm{g}$ で比較的酸性度の高い一塩基 酸を示す. 生成したゲル状物を $3 \sim 4 M$ 塩酸中で加熱す ると溶解するがふたたび沈殿が生成し，さらに還流する と微結晶の $\mathrm{ZrMo}_{2} \mathrm{O}_{7}(\mathrm{OH})_{2}\left(\mathrm{H}_{2} \mathrm{O}\right)_{2}$ が得られる82). こ れは正方晶系 I $4, \mathrm{~cd}$ に属し, $\mathrm{a}=1.145, \mathrm{c}=1.249 \mathrm{~nm}$

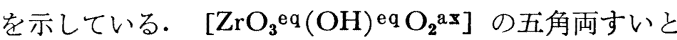

[cis $\left.\mathrm{MoO}_{4}(\mathrm{OH})\left(\mathrm{H}_{2} \mathrm{O}\right)\right]$ 八面体からなるつながった網 状構造をもっておりその結晶内で<smiles></smiles>

の水素結合鎖を形成していると考えられている，交換容 量は $8.6 \mathrm{meq} / \mathrm{g}(\mathrm{pH}=9)$ を示す. この $\mathrm{ZrMo}$ は電子交 換的性質を示し塩化スズ(II) の酸化に対して $0.18 \mathrm{meq} /$ $\mathrm{g}$ の電子交換容量をもっている ${ }^{105)}$.

2.2.10 タングステン酸ジルコニゥム $(\mathrm{ZrW})$ ． 塩 化ジルコニル溶液にタングステン酸ナトリウムを混ぜた りa) 230), 含水酸化ジルコニウムのカラムに濃厚なタング ステン酸ナトリウムの溶液を通して得られる. $\mathrm{Zr} / \mathrm{W}=$ $0.1 \sim 0.44^{10) 340)}$ の無定形物が得られる. アルカリ金属の 吸着順序は $\mathrm{Cs}^{+}>\mathrm{Rb}^{+}>\mathrm{K}{ }^{+}>\mathrm{Na}^{+}>\mathrm{Li}^{+}$の順である. これは強酸に溶解するが9)10)，適当な酸濃度条件を選ん で還流すると結晶性 ZrMo と類似した微結晶に変わる 40).

2.2.11 他のジルコニウム酸性塩 テルル酸ジルコ ニウム $(\mathrm{ZrTe})^{276)}$ ，バナジン酸ジルコニウム $(\mathrm{ZrV})^{296)}$, シュウ酸ジコニウム $(\mathrm{ZrOx})^{212}$ およびケイ酸ジルコニ ウム $\left.(\mathrm{ZrSi})^{310}\right)$ などが報告されている. 上の方法と同様 な方法で調製される，ZrTe については，45 種イオンに 

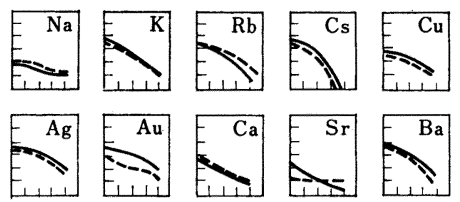

$E^{\mathrm{Zn}}$
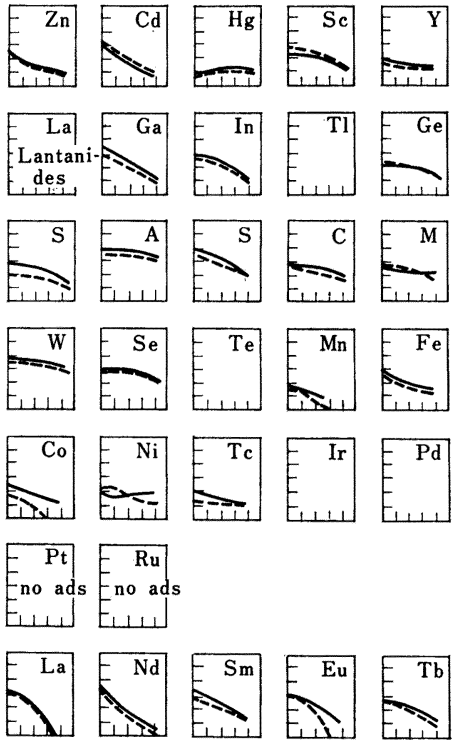

rm
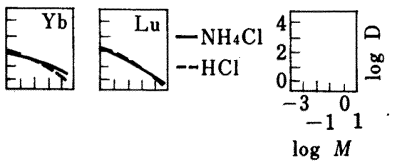

Fig. 9-4 D values on zirconium tellurate in $\mathrm{H}^{+}$ and $\mathrm{NH}_{4}+$ forms for different ions, as a function of the $\mathrm{HCl}$ and $\mathrm{NH}_{4} \mathrm{Cl}$ concentration

ついて $\mathrm{pH}$ または $\mathrm{pNH}_{4}+$ と $K_{d}$ の関倸が報告されて

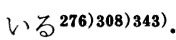

\section{3 チタン塩類}

リン酸ジルコニウムからの類推からチタン，トリウ ム, スズ(IV) などのリン酸塩の研究がよく行なわれた。

2.3.1 リン酸チタン $($ TiP $)$ リン酸ジルコニウムと 類似した調製条件で $\mathrm{P} / \mathrm{Ti}$ の異なった無定形物 107) 2411) 結晶性の TiP が得られる 16)32) 199) 217). 無定形の $\mathrm{P} / \mathrm{Ti}$ は $0.6 \sim 2.0$ までで，最高 $7.5 \mathrm{meq} / \mathrm{g}$ の交換容量を示す 241). 他のリン酸塩（無定形）と同様に $\mathrm{Cs}^{+}$に対して強 い選択性を示す241).

結晶性 $\mathrm{TiP}$ は $\mathrm{Ti}\left(\mathrm{HPO}_{4}\right)_{2} \cdot \mathrm{H}_{2} \mathrm{O}$ の組成をもち, 層間 距離 $0.756 \mathrm{~nm}$ をもつ $\alpha-\mathrm{ZrP}$ と同形で 1 モルの水分は 構造をほとんど变えないで脱水する自由水 (free water)
である16)199214). Table III に示したように $\mathrm{K}^{+}$より大 きいイオンに対してイオンふるい效果があり, $\mathrm{Na}^{+}$に対 して $7.15 \mathrm{meq} / \mathrm{g}$ を示す ${ }^{16)}$. ナトリウム形に変えるとd 値が大きくなり，また結晶化度は小さくなる，興味ある ことは結晶性 TiP に溶液中からでも気相からでもアる ンが吸着されると, 一方方向の格子の久が増加する.こ れはモンモりロ+イトへのアミンの吸着とよく類似して いる.

分析化学への応用では表に示したような分離例があり キューリ一単位の分離に応用される可能性がある.

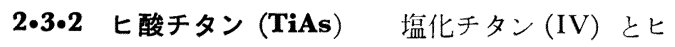
酸ナトリウムの $0.05 M$ 溶液を加えると無定形の TiAs が得られる. 乾燥物はガラス状 (ゲル状) であり, 添加 比によって組成が変化する. チタンにヒ素がモル比で $1: 1$ の割合程度が最も安定なものが得られる263)。交換 容量は約 $1 \mathrm{meq} / \mathrm{g}(\mathrm{pH}=6)$, で $10 \mathrm{~N}$ 塩酸には溶解する が $6 N$ 以下の酸やアルカリ性溶液にも安定である. 0.1 $M$ 水酸化ナトリウム十塩化ナトリウム溶液による滴定 曲線はあとで述べる TiW，TiMo，TiP と類似したみ かけ上一塩基性酸で結晶性にみられるような二段の飛躍 はみられない.アルカリ土類金属の選択性は $\mathrm{Ba}^{2+}>\mathrm{Sr}^{2+}$ $>\mathrm{Mg}^{2+}>\mathrm{Ca}^{2+}$ となり $\mathrm{Ca}^{2+}$ の吸着に特異性が認めら れる. 47 種金属について TiAs を含浸させた紙で 0.1 $N$ 硝酸に怙ける $R_{f}$ 值を測定した ${ }^{243)}$. クロマトグラフ 用紙はよく行なわれるように塩化チタン(IV) 溶液に短 時間浸し, 風乾後, ヒ酸ナトリウム溶液に浸しさらにナ トリウム形に変えて風乾後使用している. 一般的にいっ て 4 価金属イオンの $R_{f}$ 值はゼロであり, 他の金属と分 離することが可能である. さらに，TiAs として有効な $R_{f}$ 值 $\left(R_{i}^{*}\right.$ で表している $)$ を $\mathrm{pH}$ を变えて測定し, Batch 法による $K_{d}$ 值と比較した ${ }^{271)}$. Qureshi275) らの 結果より，水および $0.01 M$ 硝酸溶液中における 26 元 素の $K_{d}$ を元素ごとにプロットした. (Fig. 10-1，2). 文 献 248）の值とは若干異なるが $\mathrm{La}^{3+}, \mathrm{Ce}^{3+}, \mathrm{Sm}^{3+}$, $\mathrm{Fe}^{3+}$ や $\mathrm{Pb}^{2+}$ が水中で大きな $K_{d}$ 值をもち, 水を溶䜅 液とし $\mathrm{Pb}^{2+}$ から $\mathrm{Mg}^{2+}, \mathrm{Cu}^{2+}, \mathrm{Zn}^{2+}, \mathrm{Ga}^{3+}$ を分離で きる.

結晶性 TiAs は無定形 TiAs を $8 M$ 七酸溶液で $45 \mathrm{hr}$ 還流して得られ, その組成は $\mathrm{Ti}\left(\mathrm{HAsO}_{4}\right)_{2} \cdot \mathrm{H}_{2} \mathrm{O}$, 理論 的に $5.8 \mathrm{meq} / \mathrm{g}$ の交換容量を示す. $\mathrm{pH}$ 滴定曲線は一 塩基性酸を示し, 酸性度は $\mathrm{TiAs}<\mathrm{TiP}$ を示す. イオン ふるい効果はセシウムにおいて顕著に認められる。この 交換体は高い $\mathrm{pH}^{\mathrm{5}}$ ) で加水分解しヒ酸を溶液中に放出す るので低い $\mathrm{pH}$ で安定である.

* $R_{i}=R_{f}$ (Paper + TiAs) $-R_{f}$ (paper) 


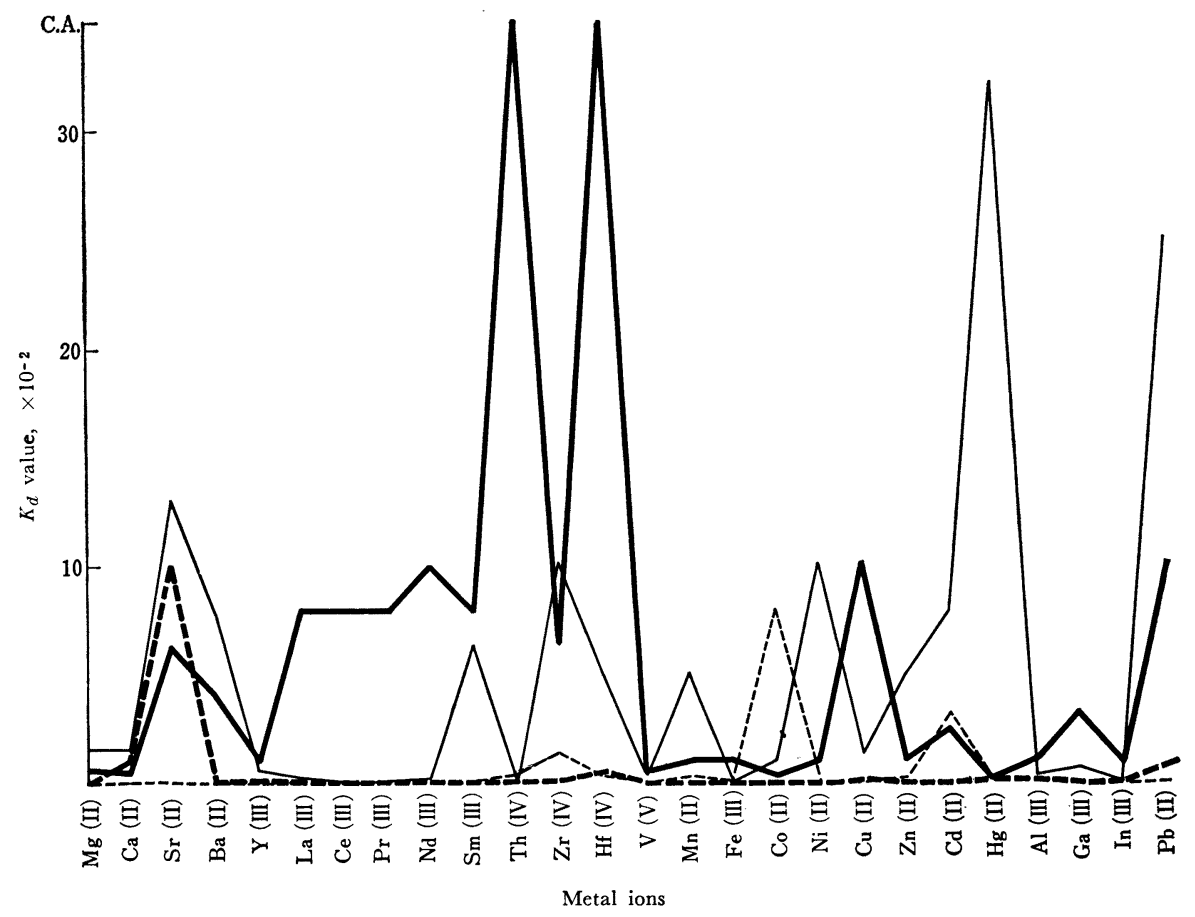

Fig. 10-1 $K_{d}$ values of various metal ions in water and $0.01 M \mathrm{HNO}_{3}$ on titanium tungstate and selenite

$K_{d}$ values were taken from ref. - In water on titanium tungstate; ----- In $0.01 M \mathrm{HNO}_{3}$ on titanium tungstate; - In water on titanium selenite; -...- In $0.01 \mathrm{M} \mathrm{HNO}_{3}$ on titanium selenite

2.3.3 アンチモン酸チタン (TiSb) 塩化チタン(IV) の溶液に $0.1 M$ 五塩化アンチモンを加えたのちアンモ 二ア水で沈殿を生成させるか 259)260) $\left[\mathrm{Sb}(\mathrm{OH})_{6}\right]$ - の溶液 を加えて沈殿を生成させるかして得られる ${ }^{130)} . \mathrm{Sb} / \mathrm{Ti}=$ 1.0 の無定形の 沈殿が得られ交換容量は $0.7 \mathrm{meq} / \mathrm{g}^{260)}$ が報告され，Gill らによりイオンの種類によって異なる 0.93 2.0 meq $/ \mathrm{g}$ の值が 報告されている ${ }^{130)}$. この構造 は Qureshi らによると酸化チタン (IV) と酸化アンチモ ン(V) から縮合体によって積み重ねられ， $\mathrm{Sb}-\mathrm{OH}$ 基が 交換容量に寄与していると推定した. 各種金属イオンの 分布係数值は調製法によって異なり, さらに出発原料に よって異なっている. Fig. 10-2 に示したように高原子 価のものほどよく吸着され，4 価金属では $0.01 M$ 硝酸 液溶中でもほとんど完全に吸着される.

2.3.4 タングステン酸チタン (TiW) 塩化チタン (IV) 溶液にタングステン酸ナトリウムを加えさらにア ンモニア水で $\mathrm{pH}$ を 2 3に調節して得られた(TiW-1). 同様に塩化チタンの代わりに $\mathrm{TiO}\left(\mathrm{SO}_{4}\right)_{2}$ を出発原料と して (TiW-2) が得られる. れぞれの交換容量は前者で そはイオンの種類により $0.42 \sim 0.77 \mathrm{meq} / \mathrm{g}$ ，後者では
$0.62 \sim 1.02 \mathrm{meq} / \mathrm{g}$ 荙示す. 交換容量と分布係数の関係 は特異的であり，交換容量は $\mathrm{Ca}^{2+}$ について $(\mathrm{TiW}-1)$ と (TiW-2) ではそれぞれ 0.46 と $1.02 \mathrm{meq} / \mathrm{g}, \mathrm{Mg}^{2+}$ に ついて 0.52 と $0.76 \mathrm{meq} / \mathrm{g}$ であるのに対し， $K_{d}$ 值は $\mathrm{Ca}^{2+}$ についてそれぞれ 1300 と 88, $\mathrm{Mg}^{2+}$ について 88 と 1320 の值を示している. これを利用して $\mathrm{Ca}^{2+}$ と $\mathrm{Mg}^{2+}$ の分離を $\mathrm{TiW}-1$ で行なっている.

結晶性 TiW は TiW の比を 1: 1.3 になるようにし て無定形 TiW を調製したのち $12 \mathrm{hr}$ その母液と還流し て得られる250) . 交換容量はアルカリ金属イオンの種類に よって $0.2(\mathrm{Li}) \sim 1.0(\mathrm{Cs}) \mathrm{meq} / \mathrm{g}$ まで変化する. 組成は $\left\{\left[\mathrm{Ti}(\mathrm{OH})_{3}\right]_{3}\left[\mathrm{WO}_{3} \mathrm{H}_{2} \mathrm{O}\right]\left[\mathrm{WO}_{3} \mathrm{OH}\right]_{3}\right\} \cdot 5.5 \mathrm{H}_{2} \mathrm{O}$ で表わ され, 無定形のものよりはるかに安定である. $\mathrm{Zr}^{4+}$ と $\mathrm{Hf}^{4+}$ や $\mathrm{Ba}^{2+}$ と $\mathrm{Sr}^{2+}$ などの $K_{d}$ 值の比は大きい. Fig. 10-1 に示したように $\mathrm{Pb}^{2+}$ や水銀 $(\mathrm{II}) \cdot$ の $K_{d}$ 值が著し く大きいのが特長である.

2.3.5 モリブデン酸チタン (TiMo) ${ }^{101) 266) ~ T i W ~}$ と同様な調製法で得られ，Mo/Ti が $0.5 \sim 2.0$ の組成 をもち，交換容量も $0.8 \sim 1.6 \mathrm{meq} / \mathrm{g}$ の広い範囲にわた うている. これらは $\mathrm{Pb}^{2+}, \mathrm{Ba}^{2+}$ ，タリウム(I) および 


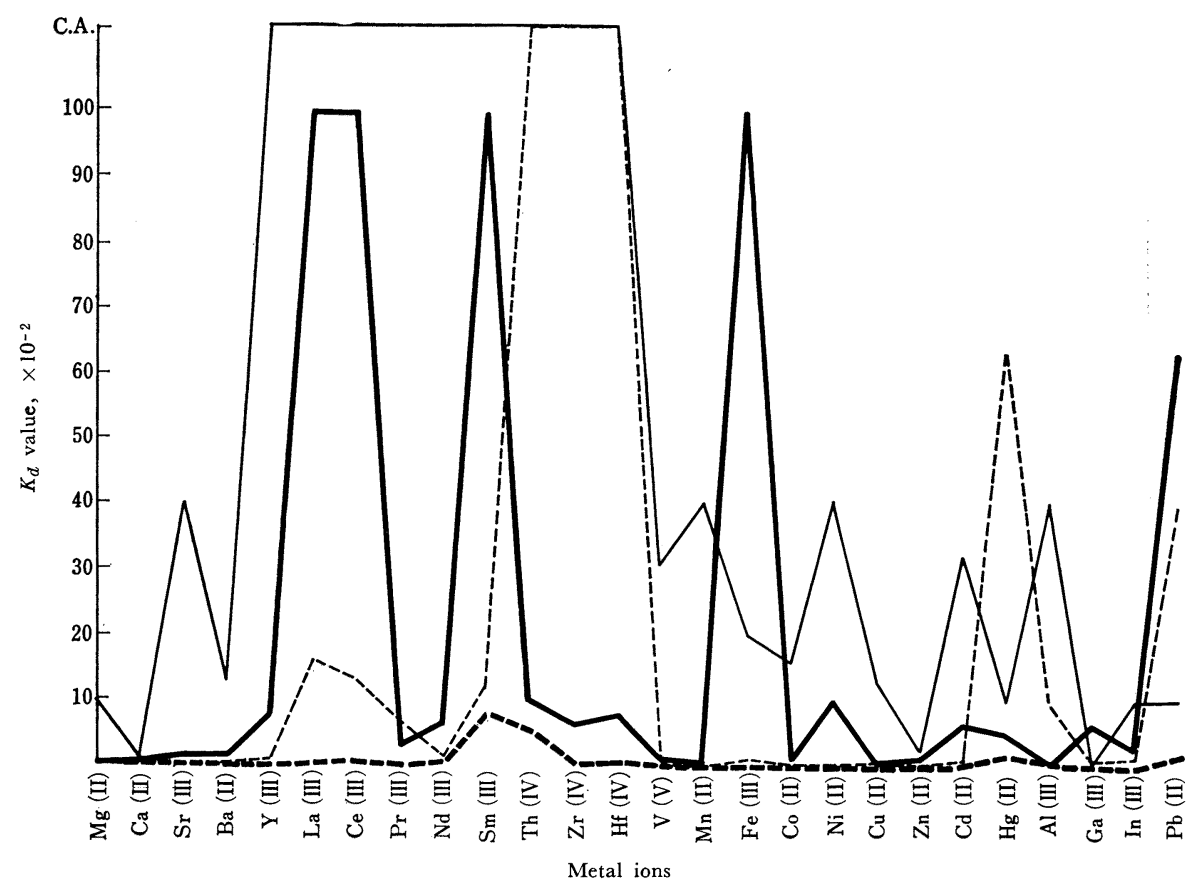

Fig. 10-2 $K_{d}$ values of various metal ions in water and $0.01 M \mathrm{HNO}_{3}$ on titanium antimonate and arsenate

$K_{d}$ values were taken from ref. - In water on titanium antimonate; -..... In $0.01 M \mathrm{HNO}_{3}$ on titanium antimonate; - In water on titanium arsenate; ..... In $0.01 \mathrm{M} \mathrm{HNO}_{3}$ on titanium arsenate

$\mathrm{K}+$ に対して高い選択性をもっている.

\subsection{6 バナジン酸チタン $(\mathrm{TiV}){ }^{270)} \quad 0.5 M$ 塩化チ} タン $(\mathrm{IV})$ 溶液と $0.5 \mathrm{M}$ バナジン酸 $(\mathrm{V})$ 溶液を混ぜ $\mathrm{pH}$ $=0$ 飞水酸化ナトリウムで調節すると暗かっ色の沈殿が 得られる. 組成は $\left[\mathrm{Ti}_{3}\left(\mathrm{~V}_{3} \mathrm{O}_{9} \cdot 1.5 \mathrm{H}_{2} \mathrm{O}\right)_{4} 13 \mathrm{H}_{2} \mathrm{O}\right]_{n}$ と推 定され, $0.65 \mathrm{meq} \mathrm{Na} / \mathrm{g} \sim 0.42 \mathrm{meq} \mathrm{Ba}^{2+} / \mathrm{g}$ の交換容量 を示し， $0.5 M$ 硝酸に安定である ( $1 M$ 水酸化ナトリウ ムに不安定).

熱安定性はチタン塩類中最もよく, $300^{\circ} \mathrm{C}$ で TiV》 TiW $>$ TiAs $>$ TiMo の順である. アルカリ土金属の吸 着順序は $\mathrm{Sr}^{2+} \gg \mathrm{Ba}^{2+} \sim \mathrm{Ca}^{2+}>\mathrm{Mg}^{2+}$ の順であり, $\mathrm{Sr}^{2+}$ と $\mathrm{Pb}^{2+}$ に強い選択性が認められる. $\mathrm{Sr}^{2+}$ と他のアル カリ土類金属イオンとの分離係数は他のチタン塩類より もはるかにすぐれているのが TiV の特長であり, $2 \mathrm{~g}$ の カラム (i. d. $=3.9 \mathrm{~mm}$ ) で $\mathrm{Sr}^{2+}$ と他のアルカリ土類金 属の分離に成功している.

2.3.7 セレン酸チタン(TiSe) ${ }^{257)}$ 塩化チタン(IV) とセレン酸ナトリウム溶液を混ぜて得られる. 添加比, $\mathrm{pH}$ や濃度によってそれらの組成が変化する. 一般に低 い $\mathrm{pH}$ から得られたものはセレンに富む組成のものが得
られ，交換容量は $0.45 \sim 0.78 \mathrm{meq} / \mathrm{g}$ を示す. セレンに 富むほど不安定となるが 中性溶液では 比較的安定であ る.いずれも無定形であるが物理的に安定でカラムとし て使用できる.この $\mathrm{TiSe}$ の特長は $\mathrm{Cd}^{2+}$ に対して選択 性があり，有機イオン交換体では困難な $\mathrm{Zn}^{2+}$ と $\mathrm{Cd}^{2+}$ とを $2 \mathrm{~g}$ (i. d. $=0.68 \mathrm{~mm}$ )の小カラムで分離できる.

\section{4 スズ(IV) 塩類}

Inoue ら 148～150) によって最初のリン酸スズイオン交 換体が報告されて以来，七素，アンチモン，タングステ ン，モリブデンなどのイオン交換体が合成され，それら のイオン交換性が研究されている.

2.4.1 リン酸スズ(IV)（SnP) 塩化スズ(IV) の 溶液に $\mathrm{pH}$ の異なったりン酸二水素ナトリウム溶液を加 えると $\mathrm{P} / \mathrm{Sn}$ が 1.25〜1.50 の無定形 $\mathrm{SnP}$ が得られる 150) 241)。乙れは $\mathrm{ZrP}$ よりも弱いみかけ上一㻥基性酸の 滴定曲線を示し， P/Sn が增加するとともに交換容量は 増加し 1.2 1.44 meq $/ \mathrm{g}$ の間に極大がある.これは 250 ${ }^{\circ} \mathrm{G}$ で 8 日間熱処理しても $10^{9} \mathrm{r}$ の 線を照射しても交換 容量にほとんど影響しない(148). $\mathrm{Sr}^{2+}$ と $\mathrm{Cs}^{+}$の分離に 
Table VII Inorganic separation of various inorganic ion exchanger-acid salts, heteropolyacid-acid salts, heteropolyacid salts and insoluble ferrocyanide

\begin{tabular}{|c|c|c|c|c|c|}
\hline Elements & Separation from & Eluent & Elution order & Note & ferences \\
\hline \multicolumn{6}{|c|}{ 1. Zirconium phosphate ( $\mathrm{ZrP})$} \\
\hline $\mathrm{Na}, \mathrm{K}, \mathrm{Rb}, \mathrm{Cs}$ & mutual & & $\mathrm{Na}-\mathrm{K}-\mathrm{Rb}-\mathrm{Cs}$ & Gs not eluted & 243) \\
\hline Alkali metals & mutual, $\mathrm{Ca}, \mathrm{Sr}, \mathrm{Ba}$ & $\mathrm{NH}_{4} \mathrm{Cl}$ & Li first & automated & 43) \\
\hline $\mathrm{K}, \mathrm{Rb}, \mathrm{Cs}$ & mutual & $\begin{array}{l}2 M \mathrm{HCl}-0.5 M \mathrm{NH}_{4} \mathrm{Cl}+0.5 M \mathrm{HCl} \\
\quad-3.6 M \mathrm{NH}_{4} \mathrm{Cl}+4 M \mathrm{NH}_{3}\end{array}$ & $\mathrm{~K}-\mathrm{R} \mathrm{b}-\mathrm{Cs}$ & $0.6 \phi \times 3 \mathrm{~cm}\left(50^{\circ} \mathrm{C}\right)$ & 222) \\
\hline $\mathrm{Rb}$, Cs & mutual & $\begin{array}{l}0.1 \mathrm{M} \mathrm{NH}_{4} \mathrm{NO}_{3} \text {-sat. } \\
\mathrm{NH}_{4} \mathrm{NO}_{3}+\mathrm{HNO}_{3}\end{array}$ & $\mathrm{Rb}-\mathrm{Cs}$ & $0.6 \phi \times 2.5 \mathrm{~cm}\left(83^{\circ} \mathrm{C}\right)$ & 41) \\
\hline Cs & rock & $\mathrm{BM}-\mathrm{HF}$ & Cs retained and eluted & $0.2 \mathrm{ppm}$ Cs detn. & 231) \\
\hline Cs & $\mathrm{Na}, \mathrm{K}$ & $0.1 M \mathrm{HClO}_{4}$ & $\mathrm{Cs}-\mathrm{K}, \mathrm{Na}$ & TLG mixed with paper & 27) \\
\hline Cs & reprocessing soln. & $\mathrm{BM}(\mathrm{pH}=8 \sim 9)$ & Cs retained & $\begin{array}{l}\text { AWP or KWP added } \\
(2 \%)\end{array}$ & 206) \\
\hline Cs & $\mathrm{Cs}, \mathrm{Sr}, \mathrm{Ba}$ & $0.5 M \mathrm{HCI}$ & $\mathrm{Ca}, \mathrm{Sr}, \mathrm{Ba}-\mathrm{Cs}$ & paper & 232) \\
\hline Cs & $\begin{array}{l}\mathrm{Sr}, \mathrm{UO}_{2}^{2+}, \mathrm{Ce}, \mathrm{Y} \\
\mathrm{RuNO}^{3+}, \mathrm{Ru}^{4+}\end{array}$ & & Cs retained & & 236) \\
\hline Cs & \multicolumn{2}{|l|}{ radio active waste soln. } & Cs retained & & 141) \\
\hline Cs & fission product soln. & $\begin{array}{l}\mathrm{BM}\left(2 M \mathrm{HNO}_{3}\right)-\% M \\
\mathrm{CH}_{3} \mathrm{COONH}_{4}\end{array}$ & Cs retained and eluted & $\mathrm{ZrP}+\mathrm{AWP}$ & 244) \\
\hline Cs & reprocessing soln. & & Gs retained & & 46) \\
\hline $\mathrm{Na}, \mathrm{K}, \mathrm{Rb}, \mathrm{Cs}$ & mutual & - & $\mathrm{Na}-\mathrm{K}-\mathrm{Rb}-\mathrm{Cs}$ & Cs not eluted & 243) \\
\hline Alkali metals & mutual, $\mathrm{Ca}, \mathrm{Sr}, \mathrm{Ba}$ & $\mathrm{NH}_{4} \mathrm{Cl}$ & Li first & automated & 43) \\
\hline $\mathrm{K}, \mathrm{Rb}, \mathrm{Cs}$ & mutual & $\begin{array}{l}2 M \mathrm{HCl}-0.5 \mathrm{MHCl}+0.5 \mathrm{MNH}_{4} \mathrm{Gl} \\
-3.6 M \mathrm{NH}_{4} \mathrm{Gl}+4 M \mathrm{NH}_{4} \mathrm{OH}\end{array}$ & $\mathrm{K}-\mathrm{Rb}-\mathrm{Cs}$ & $0.6 \phi \times 3 \mathrm{~cm}\left(50^{\circ} \mathrm{C}\right)$ & 222) \\
\hline $\mathrm{Rb}, \mathrm{Cs}$ & mutual & $\begin{array}{l}0.1 \mathrm{M} \mathrm{NH}_{4} \mathrm{NO}_{3} \text {-sat. } \\
\mathrm{NH}_{4} \mathrm{NO}_{3}+\mathrm{HNO}_{3}\end{array}$ & $\mathrm{Rb}-\mathrm{Cs}$ & $0.6 \phi \times 2.5 \mathrm{~cm}\left(83^{\circ} \mathrm{C}\right)$ & 41) \\
\hline Cs & rock & $\mathrm{BM}-\mathrm{HF}$ & Cs retained and eluted & $0.2 \mathrm{ppm}$ Cs detn. & 231) \\
\hline Cs & $\mathrm{K}, \mathrm{Na}$ & $0.1 M \mathrm{HClO}_{4}$ & $\mathrm{Cs}-\mathrm{K}, \mathrm{Na}$ & $\begin{array}{l}\text { TLC mixed with } \\
\text { cellulose }\end{array}$ & 27) \\
\hline Cs & reprocessing soln. & $\mathrm{BM}(\mathrm{pH}$ 8 9) & Cs retained & $\begin{array}{l}\text { AWP or KWP } \\
\text { added }(<20 \%)\end{array}$ & 206) \\
\hline Cs & $\mathrm{Ca}, \mathrm{Sr}, \mathrm{Ba}$ & $0.5 M \mathrm{HCl}$ & $\mathrm{Ca}, \mathrm{Sr}, \mathrm{Ba}-\mathrm{Cs}$ & $\begin{array}{l}\text { paper impregnated } \\
\text { with } \mathrm{ZrP}\end{array}$ & 232) \\
\hline Cs & $\begin{array}{l}\mathrm{Sr}, \mathrm{UO}_{2}^{2+}, \mathrm{Ce}, \mathrm{Y} \\
\mathrm{RuNO}^{3+}, \mathrm{Ru}^{4+}\end{array}$ & - & Cs retained & - & 236) \\
\hline Cs & redioactive waste soln. & - & Cs retained & - & 141) \\
\hline${ }^{137} \mathrm{Cs}$ & fission product soln. & $\mathrm{BM}\left(2 \mathrm{M} \mathrm{HNO}_{3}\right)-5 \mathrm{MCH}_{3} \mathrm{COONH}_{4}$ & Cs retained and eluted & $\mathrm{ZrP}+\mathrm{AWP}$ & 244) \\
\hline${ }^{137} \mathrm{Cs}$ & reprocessing soln. & - & Cs retained & - & 46) \\
\hline $\mathrm{Cs}, \mathrm{Ba}$ & mutual & dil. acid-5M $\mathrm{NH}_{4} \mathrm{NO}_{3}$ & $\mathrm{Ba}-\mathrm{Cs}$ & - & 206) \\
\hline${ }^{90} \mathrm{Sr},{ }^{91} \mathrm{Y},{ }^{134} \mathrm{Cs}$ & mutual & - & - & - & 292) \\
\hline $\mathrm{Cs}, \mathrm{Sr}, \mathrm{UO}_{2}$ & mutual & - & - & - & 5) \\
\hline $\mathrm{Ba}, \mathrm{Sr}, \mathrm{Ca}$ & mutual & $0.9 M \mathrm{NH}_{4} \mathrm{Cl}$ & $\mathrm{Ba}-\mathrm{Sr}-\mathrm{Ca}$ & $\begin{array}{l}\text { paper impregnated } \\
\text { with } \mathrm{ZrP}\end{array}$ & 232) \\
\hline${ }^{45} \mathrm{Ca},{ }^{46} \mathrm{Sc}$ & mutual & $0.5 M \mathrm{HCl}$ & $\mathrm{Ca}-\mathrm{Sc}$ & $\begin{array}{l}0.5 \phi \times 17 \mathrm{~cm} \mathrm{F.S.} \\
1 M \mathrm{HCl}\end{array}$ & $341)$ \\
\hline $\mathrm{Ca}, \mathrm{Sc}^{3+}$ & mutual & - & 一 & - & 283) \\
\hline $\mathrm{Sr}$ & Cs, $\mathrm{Y}$ or $\mathrm{Ba}$ & - & - & - & 295) \\
\hline $\mathrm{Sr}$ & $\mathrm{Ce}, \mathrm{Eu}, \mathrm{Zr}, \mathrm{Pu}^{4+}$ & - & Sr retained & - & 236) \\
\hline${ }^{90} \mathrm{Sr},{ }^{90} \mathrm{Y}$ & mutual & - & - & - & 283) \\
\hline $\mathrm{UO}_{2}^{2+}, \mathrm{Sr}$ & mutual & - & - & - & 236) \\
\hline $137 \mathrm{mBa}$ & ${ }^{137} \mathrm{Cs}$ & - & - & - & 167) \\
\hline transition metals & water & $\mathrm{BM}$ & metal retained & $\begin{array}{c}0.9 \phi \times 22 \mathrm{~cm}, 100^{\circ} \mathrm{C} \\
\mathrm{ZrP}+\mathrm{HZrO}(1+5)\end{array}$ & 12) \\
\hline $\mathrm{Cr}(\mathrm{III})$ or $\mathrm{Mn}(\mathrm{II})$ & $\mathrm{Al}, \mathrm{Fe}(\mathrm{III})$ & $0.5 \mathrm{M} \mathrm{HCl}$ & $\mathrm{Cr}$ or $\mathrm{Mn}-\mathrm{Al}-\mathrm{Fe}$ & $\begin{array}{l}\text { paper impregnated } \\
\text { with } \mathrm{ZrP}\end{array}$ & 28) \\
\hline $\begin{array}{l}\mathrm{Cr}(\mathrm{III}), \mathrm{Cu} \\
\quad \mathrm{Fe}(\mathrm{III})\end{array}$ & mutual & $0.035 M \mathrm{HCl}+0.045 M \mathrm{NaCl} 1: 1$ & $\mathrm{Cr}-\mathrm{Cu}-\mathrm{Fe}$ & $\begin{array}{l}\text { paper impregnated } \\
\text { with } \mathrm{ZrP}\end{array}$ & 28) \\
\hline $\mathrm{Co}, \mathrm{Cu}, \mathrm{Fe}$ (III) & mutual & $0.035 M \mathrm{HCl}+0.045 M$ NaCl $1: 1$ & $\mathrm{Co}-\mathrm{Cu}-\mathrm{Fe}$ & $\begin{array}{l}\text { paper impregnated } \\
\text { with } \mathrm{ZrP}\end{array}$ & 28) \\
\hline $\mathrm{U}(\mathrm{VI}), \mathrm{Fe}(\mathrm{III})$ & $\mathrm{Th}(\mathrm{IV})$ or $\mathrm{Ti}$ & $2 M \mathrm{HCl}+4 M \mathrm{NH}_{4} \mathrm{Cl} 1: 1$ & $\mathrm{U}-\mathrm{Fe}-\mathrm{Th}$ or $\mathrm{Ti}$ & $\begin{array}{l}\text { paper impregnated } \\
\text { with } \mathrm{ZrP}\end{array}$ & 28) \\
\hline $\begin{array}{l}\mathrm{Cd}, \mathrm{Zn}, \mathrm{UO}_{2}{ }^{2+} \\
\mathrm{Fe} \text { (III) }\end{array}$ & mutual & $\mathrm{NH}_{4} \mathrm{Cl}-\mathrm{HCl}$ (for $\mathrm{Fe}$ ) & $\mathrm{Cr}-\mathrm{Zn}-\mathrm{U}-\mathrm{Fe}$ & $0.8 \phi \times 10 \mathrm{~cm}$ & 118) \\
\hline $\mathrm{Au}(\mathrm{III}), \mathrm{Ag}$ & mutual & $2 M \mathrm{HCl}$ & $\mathrm{Au}-\mathrm{Ag}$ & - & 186) \\
\hline $\mathrm{Sb}$ & $\mathrm{U}, \mathrm{Sn}$ & $\mathrm{HCl}$ & $\mathrm{U}-\mathrm{Sb}-\mathrm{Sn}$ & - & 37) \\
\hline $\mathrm{XeO}_{3}, \mathrm{HIO}_{3}$ & mutual & $\mathrm{H}_{2} \mathrm{O}-1 M \mathrm{~K}_{2} \mathrm{SO}_{4}(\mathrm{pH}$ 10.5) & $\mathrm{XeO}_{3}-\mathrm{IO}_{3}-$ & $0.3 \phi \times 5 \mathrm{~cm} \mathrm{NO}_{3}-$ form & 168) \\
\hline${ }^{144} \mathrm{Ce}(\mathrm{IV})$ & ${ }^{144} \mathrm{Pr},{ }^{144} \mathrm{Cm}(\mathrm{IV})$ & $\begin{array}{l}\left(\mathrm{NH}_{4}\right)_{2} \mathrm{~S}_{2} \mathrm{O}_{8}\left(\mathrm{Ag}^{+}\right)+1 M \mathrm{HNO}_{3} \\
\quad\left(2 \% \mathrm{H}_{2} \mathrm{O}_{2}\right)\end{array}$ & Ce eluted & addition on column & 294) \\
\hline $\mathrm{UO}_{2}^{2+}, \mathrm{Ce}, \mathrm{Eu}$ & $\mathrm{Zr}^{4+}, \mathrm{Pu}^{4+}$ & - & - & - & 236) \\
\hline $\mathrm{UO}_{2}^{2+}, \mathrm{Pu}^{4+}$ & fission product & BM-0.5M $\mathrm{HNO}_{3}-8 M \mathrm{HNO}_{3}$ & $\mathrm{U}-\mathrm{Pu}$ & - & 119) \\
\hline $\mathrm{Pu}^{4+}$ & irradiated U & - & $\mathrm{Pu}$ retained & 一 & 236) \\
\hline
\end{tabular}




\begin{tabular}{|c|c|c|c|c|c|}
\hline Elements & Separation from & Eluent & Elution order & Note & ferences \\
\hline $\mathrm{Pu}^{4+}$ & $\mathrm{Cs}, \mathrm{Sr}, \mathrm{Eu}, \mathrm{Ce}, \mathrm{Ru}^{4+}$ & - & $\mathrm{Pu}$ retained & - & 236) \\
\hline $\operatorname{Am}(V), C m(I I I)$ & mutual & $0.01 M \mathrm{HNO}_{3}-10 \mathrm{M} \mathrm{HNO}_{3}$ & $\mathrm{Am}-\mathrm{Cm}$ & $0.5 \phi \times 3 \mathrm{~cm}$ & 215) \\
\hline $\mathrm{NH}_{4}^{+}$ & urea & $\mathrm{BM}-1.24 \mathrm{M} \mathrm{CsCl}$ & urea- $\mathrm{NH}_{4}{ }^{+}$ & $0.8 \phi \times 0.8 \mathrm{~cm}$ & 333) \\
\hline $\begin{array}{l}\left(\mathrm{HOCH}_{2} \mathrm{CH}_{2}\right)_{3} \mathrm{NHCl}^{-} \\
\mathrm{HOCH}_{2} \mathrm{CH}_{2} \mathrm{NH}_{3} \mathrm{Cl}, \\
\mathrm{NH}_{4} \mathrm{Cl}^{2}\end{array}$ & mutual & $0.1 M \mathrm{HCl}$ & $\mathrm{C}_{6}-\mathrm{C}_{2}-\mathrm{NH}_{4} \mathrm{Cl}$ & $0.55 \phi \times 170 \mathrm{~cm}\left(80^{\circ} \mathrm{C}\right)$ & 280) \\
\hline $\begin{array}{c}\mathrm{C}_{8} \mathrm{H}_{17} \mathrm{NH}_{3} \mathrm{Cl} \\
\mathrm{C}_{2} \mathrm{H}_{5} \mathrm{NH}_{3} \mathrm{Cl} \\
\mathrm{CH}_{3} \mathrm{NH}_{3} \mathrm{Cl} \\
\left(\mathrm{CH}_{2} \mathrm{NH}_{3}\right) \mathrm{Cl}_{2}\end{array}$ & mutual & $0.1 M \mathrm{HCl}$ & $\begin{array}{l}\mathrm{C}_{8}-\mathrm{C}_{2}-\mathrm{C}_{1}- \\
\left(\mathrm{CH}_{2} \mathrm{NH}_{3} \mathrm{Cl}\right)_{2}\end{array}$ & $\begin{array}{l}0.55 \phi \times 42.5 \mathrm{~cm} 50^{\circ} \mathrm{C} \text {, } \\
\text { last one } 90^{\circ} \mathrm{C}\end{array}$ & 280) \\
\hline \multicolumn{6}{|c|}{ 2. Zirconium phthalophosphate ( $\mathrm{ZrPhP})$} \\
\hline $\begin{array}{l}\mathrm{Fe}(\mathrm{III}), \mathrm{Mn}(\mathrm{II}), \mathrm{Ni}, \\
\quad \mathrm{Pb}(\mathrm{II}), \mathrm{Cu}, \mathrm{Bi}(\mathrm{III}) \\
\quad \mathrm{Al}, \mathrm{Cr}(\mathrm{III}), \mathrm{Co}(\mathrm{II})\end{array}$ & $\mathrm{Zn}, \mathrm{Ag}, \mathrm{Cd}$ & $\mathrm{BM}$ & $\mathrm{Zn}, \mathrm{Ag}, \mathrm{Cd}$ not sorbed & & 67) \\
\hline \multicolumn{6}{|c|}{ 3. Zirconium pyrophosphate ( $\mathrm{ZrPyroP})$} \\
\hline${ }^{90} \mathrm{Sr}$ & ${ }^{90} \mathrm{Y},{ }^{137} \mathrm{Cs}$ & - & - & - & 100) \\
\hline${ }^{90} \mathrm{Sr},{ }^{90} \mathrm{Y}$ & mutual & - & - & - & 100) \\
\hline $\mathrm{Fe}^{3+}$ & $\mathrm{Ni}, \mathrm{Zn}$ or $\mathrm{Cu}$ & - & - & - & 238) \\
\hline $\mathrm{Cd}$ & $\mathrm{Cu}$ & - & - & - & 238) \\
\hline $\mathrm{Pb}$ & $\mathrm{Hg}$ & - & & - & 238) \\
\hline $\mathrm{UO}_{2}, \mathrm{Th}$ & mutual & - & - & - & 100) \\
\hline $\mathrm{Pu}$ & $\begin{array}{l}\mathrm{U}, \mathrm{Zr}, \mathrm{Nb}, \mathrm{Ru}, \mathrm{Ce} \\
\mathrm{Sr}, \mathrm{Cs}\end{array}$ & - & - & - & 100) \\
\hline \multicolumn{6}{|c|}{ 4. Zirconium phosphatesilicate } \\
\hline${ }^{243} \mathrm{Am},{ }^{249} \mathrm{Bk},{ }^{144} \mathrm{Ce}$ & radionuclide & $\begin{array}{l}\mathrm{BM}-1 \mathrm{M} \mathrm{HNO}_{3}-7 \mathrm{M} \mathrm{HNO}_{3}- \\
0.5 M \mathrm{HNO}_{3}\end{array}$ & $\mathrm{Am}-\mathrm{Bk}-\mathrm{Ce}$ & $\begin{array}{l}0.3 \phi \times 10 \mathrm{~cm} \mathrm{PbO}_{2} \\
\text { added }\end{array}$ & 217) \\
\hline $\mathrm{Pu}, \mathrm{U}, \mathrm{Cm}$ & $\mathrm{Yb}, \mathrm{Fe}(\mathrm{III})$ & $\begin{array}{l}\mathrm{BM}\left(0.1 M \mathrm{HNO}_{3}\right)-2 M \mathrm{HCl}- \\
2 M \mathrm{HCl}\end{array}$ & $\mathrm{Yb}, \mathrm{Fe}-\mathrm{U}-\mathrm{Pu}, \mathrm{Cm}$ & - & $52)$ \\
\hline $\mathrm{Zr}, \mathrm{Pu}(\mathrm{IV}), \mathrm{Ru}$ & mutual & $\begin{array}{l}\mathrm{BM}\left(0.5 \mathrm{MHNO}_{3}\right)-0.025 \mathrm{M} \\
\quad+1 \mathrm{M} \mathrm{HNO}_{3}\end{array}$ & $\begin{array}{l}\text { ascorbic acid } \\
\mathrm{BM}(\mathrm{Ru})-\mathrm{Pu} \\
\mathrm{Zr} \text { retained }\end{array}$ & $\begin{array}{l}\mathrm{Pu}(\mathrm{IV}) \text { reduced } \\
\text { to } \mathrm{Pu}(\mathrm{III}) \text { by } \\
\text { ascorbic acid }\end{array}$ & 320) \\
\hline${ }^{239} \mathrm{~Np}, \quad{ }^{239} \mathrm{Pu}$ & mutual & $0.5 \mathrm{M} \mathrm{HNO}_{3}-8 \mathrm{M} \mathrm{HNO}_{3}$ & $\mathrm{Pu}-\mathrm{Np}$ & $\begin{array}{l}\text { first reduced by } 0.05 M \\
\mathrm{Fe}\left(\mathrm{NH}_{2} \mathrm{SO}_{3}\right)_{2}-\mathrm{N}_{2} \mathrm{H}_{4}\end{array}$ & 229) \\
\hline $\mathrm{Pu}$ & $\mathrm{Zr}+\mathrm{Nb}$ or $\mathrm{Ru}$ & - & - & - & 218) \\
\hline \multicolumn{6}{|c|}{ 5. Zirconium antimonate $(\mathrm{ZrSb})$} \\
\hline $\mathrm{Na}^{+}$ & $\mathrm{AlCl}_{3}$ or $\mathrm{MgCl}_{2}$ & 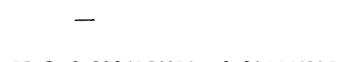 & - & $\begin{array}{l}\text { from large amount of } \\
\mathrm{Al} \text { or } \mathrm{Mg}\end{array}$ & 72) \\
\hline $\mathrm{Li}, \mathrm{Na}, \mathrm{K}, \mathrm{Cs}$ & mutual & $\mathrm{H}_{2} \mathrm{O}, 0.002 N \mathrm{HNO}_{3}-0.01 M \mathrm{HNO}_{3}$ & $\mathrm{Li}-\mathrm{Na} \cdot \mathrm{K}, \mathrm{Cs}$ & - & 4) \\
\hline $\mathrm{K}, \mathrm{Rb}, \mathrm{Na}$ & mutual & $\underset{\mathrm{NH}_{4} \mathrm{NO}_{3}}{2 \mathrm{HNO}_{3}-6.2 \mathrm{M} \mathrm{HNO}_{3}-2 \mathrm{M}}$ & $\mathrm{K}-\mathrm{Rb}-\mathrm{Na}$ & - & 240) \\
\hline $\mathrm{Cs}, \mathrm{Rb}$ & mutual & $\mathrm{HCI}(\mathrm{pH} 2.5)$ & $\mathrm{Cs}-\mathrm{Rb}$ & $\begin{array}{l}2 \phi \times 4 \mathrm{~cm} 10 \% \text { on } \\
\text { cellulose }\end{array}$ & 242) \\
\hline \multicolumn{6}{|c|}{ 6. Zirconium tungstate $(\mathrm{ZrW})$} \\
\hline $\mathrm{Na}$ & $\mathrm{Rb}$ on $\mathrm{Cs}$ & $\mathrm{NH}_{4} \mathrm{Cl}$ & - & same with $\mathrm{ZrW}$ & 102) \\
\hline $\mathrm{K}$ & Cs & $\mathrm{NH}_{4} \mathrm{Cl}$ & - & same with $\mathrm{ZrW}$ & 102) \\
\hline $\mathrm{Ca}, \mathrm{Sc}$ & mutual & - & - & - & 283) \\
\hline${ }^{90} \mathrm{Sr},{ }^{90} \mathrm{Y}$ & mutual & - & - & - & 283) \\
\hline \multicolumn{6}{|c|}{ 7. Zirconium silicate $(\mathrm{ZrSi})$} \\
\hline $\mathrm{Ca}$ & $\mathrm{Sr}$ & - & - & - & 310) \\
\hline $\mathrm{Th}^{4+}$ & $\mathrm{Sm}^{3+}$ & - & - & - & $310)$ \\
\hline \multicolumn{6}{|c|}{ 8. Titanium phosphate (TiP) } \\
\hline $\mathrm{K}, \mathrm{Na}$ & mutual & $\left(\mathrm{CH}_{3}\right)_{4} \mathrm{NAc}+\mathrm{HAc}(\mathrm{pH} 5)$ & $\mathrm{Cs}-\mathrm{Na}$ & TLC, mixed with cellulose & se 27) \\
\hline Cs & reprossing soln. & - & Cs retained & - & 57) \\
\hline Cs & $\mathrm{Na}$ & $\mathrm{NH}_{3}+\mathrm{H}_{3} \mathrm{PO}_{4}(\mathrm{pH} 7)$ & $\mathrm{Na}-\mathrm{Cs}$ & TLC, mixed with cellulose & se 27) \\
\hline Cs & reprossing soln. & $\mathrm{NH}_{4} \mathrm{NO}_{3}$ & Cs retained & - & $50)$ \\
\hline $228 \mathrm{Th}$ & ${ }^{227} \mathrm{Ac}$ & $\mathrm{BM}\left(4 M \mathrm{HNO}_{3}\right)-2 M \mathrm{H}_{2} \mathrm{SO}_{4}$ & Th retained and eluted & at $65^{\circ} \mathrm{C}$ & 147) \\
\hline \multicolumn{6}{|c|}{ 9. Titanium phosphate silicate (TiPSi) } \\
\hline${ }^{94} \mathrm{Zr}$ & ${ }^{137} \mathrm{Cs}$ & $\mathrm{BM}\left(2 \mathrm{M} \mathrm{HNO}_{3}\right)$ & Zr retained & - & 219) \\
\hline \multicolumn{6}{|c|}{ 10. Titanium arsenate (TiAs) } \\
\hline $\mathrm{Ba}, \mathrm{La}$ & mutual & $\begin{array}{l}0.1 M \mathrm{HNO}_{3} \text { in } 90 \% \text { acetone } \\
-2 M \mathrm{HNO}_{3}\end{array}$ & $\mathrm{Ba}-\mathrm{La}$ & - & 275) \\
\hline $\mathbf{C a}$ & $\mathrm{Mg}$ or $\mathrm{Sr}$ & $\begin{array}{l}0.05 M \mathrm{HNO}_{3}-0.5 \mathrm{M} \mathrm{NH}_{4} \mathrm{NO}_{3} \\
+0.05 \mathrm{MNO} \mathrm{HNO}_{3}\end{array}$ & $\mathrm{Sr}-\mathrm{Ca}, \mathrm{Mg}-\mathrm{Ca}$ & - & 248) \\
\hline
\end{tabular}




\begin{tabular}{|c|c|c|c|c|c|}
\hline Elements & Separation from & Eluent & Elution order & Note & erences \\
\hline \multicolumn{6}{|c|}{ 16. Thorium arsenate (ThAs) } \\
\hline $\mathrm{Li}$ & $\mathrm{Na}$ & - & $\mathrm{Li}$ retained & batch & $30)$ \\
\hline \multicolumn{6}{|c|}{ 17. Thorium molybdate (ThMo) } \\
\hline $\mathrm{Fe}^{3+}$ & $\begin{array}{l}\text { binary with Co, } \\
\text { Zn, Cu }\end{array}$ & $\mathrm{H}_{2} \mathrm{O}-2 M \mathrm{NH}_{4} \mathrm{Cl}+0.1 M \mathrm{HCl}$ & Fe last & - & 254) \\
\hline \multicolumn{6}{|c|}{ 18. Cerium phosphate (CeP) } \\
\hline $\mathrm{Na}$ & Cs & $\mathrm{HCl}$ & - & - & 286) \\
\hline $\mathrm{Li}, \mathrm{Na}, \mathrm{K}$ & mutual & - & $\mathrm{Li}-\mathrm{Na}-\mathrm{K}$ & TLC support for paper & $31)$ \\
\hline Cs & $\mathrm{Ba}$ & $\mathrm{NH}_{4} \mathrm{Cl}, \mathrm{HCl}$ or $\mathrm{HClO}_{4}$ & - & - & 286) \\
\hline $\mathrm{Co}, \mathrm{Eu}(\mathrm{III})$ & mutual & - & Co-Eu & TLG support for paper & $31)$ \\
\hline $\mathrm{Ag}, \mathrm{Tl}, \mathrm{Ni}$ & mutual & - & $\mathrm{Ni}-\mathrm{Ag}-\mathrm{Tl}$ & TLC support for paper & 31) \\
\hline \multicolumn{6}{|c|}{ 19. Cerium antimonate (CeSb) } \\
\hline $\mathrm{Zr}^{4+}, \mathrm{Th}^{4+}$ & mutual & $\mathrm{H}_{2} \mathrm{O}-0.05 \mathrm{M} \mathrm{NH}_{4} \mathrm{Cl}+0.01 M \mathrm{HCl}$ & $\mathrm{Th}-\mathrm{Zr}$ & - & 126) \\
\hline $\mathrm{Cu}, \mathrm{Mn}^{2+}$ & mutual & $\mathrm{H}_{2} \mathrm{O}-0.05 M \mathrm{NH}_{4} \mathrm{Cl}+0.01 M \mathrm{HCl}$ & $\mathrm{Mn}-\mathrm{Cu}$ & - & 126) \\
\hline $\mathrm{Fe}^{3+}, \mathrm{Al}$ & mutual & $\mathrm{H}_{2} \mathrm{O}-0.05 M \mathrm{NH}_{4} \mathrm{CI}+0.01 M \mathrm{HCl}$ & $\mathrm{Al}-\mathrm{Fe}$ & - & 126) \\
\hline $\mathrm{Hg}^{2+}$ & $\begin{array}{l}\text { binary with } \mathrm{Cd} \\
\mathrm{Zn}, \mathrm{Tl}^{+} \text {or } \mathrm{Pd}\end{array}$ & $\mathrm{H}_{2} \mathrm{O}-0.5 M \mathrm{NH}_{4} \mathrm{Cl}+0.1 M \mathrm{HCl}$ & $\mathrm{Cd}, \mathrm{Zn}, \mathrm{Tl}$ or $\mathrm{Pb}-\mathrm{Hg}$ & - & 122) \\
\hline \multicolumn{6}{|c|}{ 20. Cerium tungstate $(\mathrm{CeW})$} \\
\hline $\mathrm{Cr}^{3+}, \mathrm{Al}$ & mutual & $\mathrm{H}_{2} \mathrm{O}-0.2 \mathrm{M} \mathrm{NH}_{4} \mathrm{Cl}+0.02 M \mathrm{HCl}$ & $\mathrm{Cr}-\mathrm{Al}$ & - & 314) \\
\hline $\mathrm{Hg}^{2+}$ & $\begin{array}{l}\text { binary with } \mathrm{Pd} \text {, } \\
\text { Cd or } \mathrm{Zn}\end{array}$ & $\mathrm{H}_{2} \mathrm{O}-0.2 \mathrm{M} \mathrm{NH}{ }_{4} \mathrm{Cl}+0.02 M \mathrm{HCl}$ & $\mathrm{Pb}, \mathrm{Cd}$ or $\mathrm{Zn}-\mathrm{Hg}$ & - & 314) \\
\hline \multicolumn{6}{|c|}{ 21. Stannic phosphate (SnP) } \\
\hline $\mathrm{Na}, \mathrm{Cs}$ & mutual & $0.1 M \sim 3 M \mathrm{NH}_{4} \mathrm{Cl}$ & $\mathrm{Na}-\mathrm{Cs}$ & - & 150) \\
\hline $\mathrm{K}$ & $\begin{array}{l}\text { binary with } \mathrm{V}^{4+} \text {, } \\
\mathrm{Ca} \text { or } \mathrm{Hg}\end{array}$ & $0.1 M \mathrm{NH}_{4} \mathrm{Cl}$ & $\mathrm{K}$ fast & paper & 255) \\
\hline $\mathrm{Cs}, \mathrm{Mg}$ & mutual & $0.1 M \mathrm{NH}_{4} \mathrm{Cl}$ & Cs $-\mathrm{Mg}$ & paper & 255) \\
\hline Cs, Sr & mutual & $0.5 \sim 3 M \mathrm{NH}_{4} \mathrm{Cl}$ & $\mathrm{Sr}-\mathrm{Cs}$ & $0.7 \phi \times 4 \mathrm{~cm}$ & 149) \\
\hline $\mathrm{Cs}, \mathrm{Sr}$ & fission product & - & - & - & $57)$ \\
\hline $\mathrm{Cs}, \mathrm{Sr}$ & fission product & $\begin{array}{l}0.5 M \mathrm{NH}_{4} \mathrm{Cl}-1 M \mathrm{CH}_{3} \mathrm{COONH}_{4}+ \\
3 M \mathrm{NH}_{4} \mathrm{Cl}-1 M \mathrm{H}_{3} \mathrm{PO}_{4}-5 M \mathrm{HNO}_{3}\end{array}$ & $\begin{array}{l}{ }^{89} \mathrm{Sr},{ }^{90} \mathrm{Sr}-\mathrm{Cs},-\mathrm{U}- \\
3 \text { rare earth }\end{array}$ & $0.7 \phi \times 16 \mathrm{~cm}$ & 104) \\
\hline $\mathrm{Cs}, \mathrm{Ce}$ & mutual & $3 M \mathrm{NH}_{4} \mathrm{Cl}-3 M \mathrm{HNO}_{3}$ & $\mathrm{Cs}-\mathrm{Ce}$ & $0.7 \phi \times 4 \mathrm{~cm}$ & 149) \\
\hline Cs, U & mutual & $3 M \mathrm{NH}_{4} \mathrm{Cl}-3 M \mathrm{HNO}_{3}$ & Cs-U & $0.7 \phi \times 4 \mathrm{~cm}$ & 151) \\
\hline $\mathrm{Sr}$ & $\mathrm{Ce}$ or $\mathrm{Y}$ & $\begin{array}{l}0.2 M \mathrm{NH}_{4} \mathrm{Cl}-1 M \mathrm{NH}_{4} \mathrm{Cl} \\
\quad+0.5 \mathrm{M} \mathrm{HNO}_{3}\end{array}$ & $\mathrm{Sr}-\mathrm{Ce}$ or $\mathrm{Y}$ & $0.7 \phi \times 4 \mathrm{~cm}$ & 149) \\
\hline $\mathrm{Sr}, \mathrm{Cs}, \mathrm{Ce}$ & $\mathrm{Zr}$ & $\begin{array}{l}\mathrm{BM}\left(0.1 M \mathrm{HNO}_{3}\right)-0.1 M \mathrm{HNO}_{3} \\
+0.2 M \mathrm{NH}_{4} \mathrm{Cl}-3 M \mathrm{NH}_{4} \mathrm{Cl} \\
-5 M \mathrm{HNO}_{3}\end{array}$ & $\mathrm{Zr}-\mathrm{Sr}-\mathrm{Cs}-\mathrm{Ce}$ & $0.7 \phi \times 4 \mathrm{~cm}$ & 149) \\
\hline $\mathrm{Sr}, \mathrm{Cs}, \mathrm{U}$ & $\mathrm{Zr}, \mathrm{Nb}$ & BM-0.5M 3M NH${ }_{4} \mathrm{Cl}-5 M \mathrm{HNO}_{3}$ & $\mathrm{Zr}, \mathrm{Nb}-\mathrm{Sr}-\mathrm{Cs}-\mathrm{U}$ & $0.7 \phi \times 4 \mathrm{~cm}$ & 151) \\
\hline $\mathrm{Sr}, \mathrm{U}$ & mutual & $0.2 M \mathrm{NH}_{4} \mathrm{Cl}-5 M \mathrm{HNO}_{3}$ & $\mathrm{Sr}-\mathrm{U}$ & $0.7 \phi \times 4 \mathrm{~cm}$ & 151) \\
\hline $\mathrm{Cr}^{3+}$ & binary with 9 cations & $0.5 M \mathrm{HCl}$ & Cr fast & paper & 255) \\
\hline $\mathrm{Ni}$ & $\begin{array}{l}\text { binary with } \mathrm{Ag}, \mathrm{Cu} \\
\mathrm{Fe}^{3+}, \mathrm{Al} \text { or } \mathrm{Zn}\end{array}$ & $0.1 M \mathrm{NH}_{4} \mathrm{CI}$ & $\mathrm{Ni}$ fast & paper & 255) \\
\hline $\mathrm{Au}^{3+}, \mathrm{Pd}^{2+}, \mathrm{Pt}^{4+}$ & mutual & $\begin{array}{l}\mathrm{C}_{4} \mathrm{H}_{9} \mathrm{OH}-\mathrm{HCl}-10 \% \mathrm{NH}_{4} \mathrm{Cl} \\
\quad(7: 2: 1)\end{array}$ & $\mathrm{Au}-\mathrm{Pd}-\mathrm{Pt}$ & paper & 247) \\
\hline $\mathrm{Hg}^{2+}$ & $\begin{array}{l}\text { binary with } \mathrm{Bi}^{3+} \\
\mathrm{Cd} \text { or } \mathrm{Cu}\end{array}$ & $0.1 M \mathrm{NH}_{4} \mathrm{Cl}$ & $\mathrm{Hg}$ fast & paper & 255) \\
\hline $\mathrm{Tl}^{+}$ & binary with 16 cations & $0.1 M \mathrm{HNO}_{3}$ & Tl fast & paper & 255) \\
\hline $\mathrm{Ce}, \mathrm{U}$ & mutual & $1 M \mathrm{H}_{3} \mathrm{PO}_{4}-3 M \mathrm{HNO}_{3}$ & $\mathrm{U}-\mathrm{Ce}$ & $0.7 \phi \times 4 \mathrm{~cm}$ & 151) \\
\hline 28 cations & mutual & $\begin{array}{l}\mathrm{HCl}, \mathrm{HNO}_{3}, \mathrm{H}_{2} \mathrm{SO}_{4}, \mathrm{HClO}_{4} \\
\quad \text { or } 0.1 \sim 4 M \mathrm{CH}_{3} \mathrm{COOH}\end{array}$ & - & paper impregnated with & 339) \\
\hline \multicolumn{6}{|c|}{ 22. Stannic arsenate (SnAs) } \\
\hline Cs & $\begin{array}{l}\text { alkali metals } \\
\text { multivalent metals }\end{array}$ & $\mathrm{BM}\left(0.2 \mathrm{M} \mathrm{NH}_{4} \mathrm{NO}_{3}\right)$ & Cs retained & - & 298) \\
\hline $\mathrm{Ba}$ & 33 cations & $\mathrm{HBr}+2 M \mathrm{NH}_{4} \mathrm{Br}(1: 1)$ & - & TLG & 145) \\
\hline $\mathrm{Ba}$ & $\begin{array}{l}\text { binary with } \mathrm{Ca}, \mathrm{Sr} \\
\text { or } \mathrm{Mg}\end{array}$ & $\mathrm{H}_{2} \mathrm{O}-5 \% \quad \mathrm{HNO}_{3}+5 \% \quad \mathrm{NH}_{4} \mathrm{NO}_{3}$ & $\mathrm{Ba}$ last & - & 267) \\
\hline $\mathrm{Fe}^{3+}$ & $\begin{array}{l}\text { binary with } \mathrm{Ni}, \mathrm{Co} \\
\mathrm{Mn}^{2+}, \mathrm{Ca} \text { or } \mathrm{Al}\end{array}$ & Al $\mathrm{H}_{2} \mathrm{O}-5 \% \mathrm{HNO}_{3}+5 \% \mathrm{NH}_{4} \mathrm{Cl}$ & $\mathrm{Fe}$ last & - & 267) \\
\hline $\mathrm{Fe}^{2+}$ & $\begin{array}{l}\text { binary with } \mathrm{Fe}^{3+} \\
\mathrm{Cu} \text { or } \mathrm{Pb}\end{array}$ & $\begin{array}{l}1 M \mathrm{NH}_{4} \mathrm{NO}_{3}-1 M \mathrm{NH}_{4} \mathrm{NO}_{3} \\
+3 \% \mathrm{HNO}_{3}\end{array}$ & $\mathrm{Fe}^{2+}$ first & - & 256) \\
\hline $\mathrm{Cu}$ & $\mathrm{Pb}$ or $\mathrm{Fe}^{3+}$ & $\begin{array}{l}1 M \mathrm{NH}_{4} \mathrm{NO}_{3}-1 M \mathrm{NH}_{4} \mathrm{NO}_{3} \\
\quad+3 \% \mathrm{HNO}_{3}\end{array}$ & $\mathrm{Cu}$ first & - & 256) \\
\hline $\mathrm{Ge}$ & 30 cations & $0.25 M \mathrm{NH}_{4}$ Oxa. $+0.1 M$ HOxa. $1: 1$ & $1-$ & TLC & 145) \\
\hline $\mathrm{Pb}$ & $\mathrm{Zn}$ or $\mathrm{Mn}^{2+}$ & $\begin{array}{l}1 M \mathrm{NH}_{4} \mathrm{NO}_{3}-1 M \mathrm{NH}_{4} \mathrm{NO}_{3} \\
\text { in } 0.5 M \mathrm{HNO}_{3}\end{array}$ & $\mathrm{Zn}$ or $\mathrm{Mn}-\mathrm{Pb}$ & - & 268) \\
\hline
\end{tabular}




\begin{tabular}{|c|c|c|c|c|c|}
\hline Elements & Separation from & Eluent & Elution order & Note & References \\
\hline $\mathrm{UO}_{2}{ }^{2+}$ & $\begin{array}{l}\text { binary with } \mathrm{Mn}, \mathrm{Ca} \text {, } \\
\mathrm{Mg} \text { or } \mathrm{Fe}^{2+}\end{array}$ & $1 M \mathrm{NH}_{4} \mathrm{NO}_{3}-0.5 M \mathrm{HNO}_{3}$ & U last & - & 268) \\
\hline $\mathrm{UO}_{2}{ }^{2+}$ & $\mathrm{Sr}$ or $\mathrm{Cu}$ & $\begin{array}{l}1 M \mathrm{NH}_{4} \mathrm{NO}_{3} \text { in } 0.02 M \mathrm{HNO}_{3} \\
-0.5 M \mathrm{HNO}_{3}\end{array}$ & $\mathrm{Sr}$ or $\mathrm{Cu}-\mathrm{U}$ & - & 268) \\
\hline \multicolumn{6}{|c|}{ 23. Stannic antimonate ( $\mathrm{SnSb})$} \\
\hline $\mathrm{Mg}, \mathrm{Sr}$ & mutual & $\begin{array}{l}0.4 \% \mathrm{NH}_{4} \mathrm{NO}_{3}-3 \% \mathrm{NH}_{4} \mathrm{Cl} \\
\quad+0.1 M \mathrm{HNO}_{3}\end{array}$ & $\mathrm{Mg}-\mathrm{Sr}$ & - & 261) \\
\hline $\mathrm{Mg}, \mathrm{Cd}$ & mutual & $0.4 M \mathrm{NH}_{4} \mathrm{NO}_{3}-0.1 M \mathrm{HNO}_{3}$ & $\mathrm{Mg}-\mathrm{Cd}$ & - & 261) \\
\hline $\mathrm{Mg}, \mathrm{Al}$ & mutual & $\begin{array}{l}0.4 M \mathrm{NH}_{4} \mathrm{NO}_{3}-0.4 M \mathrm{NH}_{4} \mathrm{NO}_{3} \\
\quad+0.2 M \mathrm{HNO}_{3}\end{array}$ & $\mathrm{Mg}-\mathrm{Al}$ & - & 261) \\
\hline $\mathrm{Mg}, \mathrm{La}^{3+}$ & mutual & $0.4 M \mathrm{NH}_{4} \mathrm{NO}_{3}-1.5 M \mathrm{HNO}_{3}$ & $\mathrm{Mg}-\mathrm{La}$ & - & 261) \\
\hline $\mathrm{Ca}, \mathrm{La}^{3+}$ & mutual & $\begin{array}{l}0.4 M \mathrm{NH}_{4} \mathrm{NO}_{3}+0.1 M \mathrm{HNO}_{3} \\
-1.5 \mathrm{M} \mathrm{HNO}_{3}\end{array}$ & $\mathrm{Ca}-\mathrm{La}$ & - & 261) \\
\hline $\mathrm{Cd}, \mathrm{Cu}$ & mutual & $0.1 M \mathrm{HNO}_{3}-1 M \mathrm{HNO}_{3}$ & $\mathrm{Cd}-\mathrm{Cu}$ & - & 261) \\
\hline \multicolumn{6}{|c|}{ 24. Stannic molybdate (SnMo) } \\
\hline $\mathrm{Rb}$, Cs & mutual & $50 \%$ HCl-MEK-acetone (5: $3: 2)$ & - & paper & 270) \\
\hline $\mathrm{Be}, \mathrm{Al}, \mathrm{Ga}$ & mutual & $\mathrm{C}_{4} \mathrm{H}_{9} \mathrm{OH}$-conc $\mathrm{HCl}(7: 3)$ & - & paper & 270) \\
\hline $\mathrm{Mg}$ & $\begin{array}{l}\text { binary with } \mathrm{Ca}, \mathrm{Sr} \\
\text { or } \mathrm{Ba}\end{array}$ & $50 \%$ HCl-MEK-acetone $(5: 3: 2)$ & 一 & paper & 270) \\
\hline $\mathrm{Mg}, \mathrm{Al}$ & mutual & $2 \% \mathrm{NH}_{4} \mathrm{Cl}-1 \% \mathrm{HNO}_{3}$ & $\mathrm{Mg}-\mathrm{Al}$ & - & 252) \\
\hline $\mathrm{Fe}^{3+}$ & $\begin{array}{l}\text { binary with } \mathrm{Al} \\
\mathrm{Mn}^{2+}, \mathrm{Ni}\end{array}$ & $0.1 M \mathrm{NH}_{4} \mathrm{Cl}-1 M \mathrm{HNO}_{3}$ & Fe last & - & 252) \\
\hline $\mathrm{Cu}$ & $\mathrm{Ni}$ or $\mathrm{Al}$ & $0.1 M \mathrm{NH}_{4} \mathrm{Gl}-1 M \mathrm{HNO}_{3}$ & $\mathrm{Cu}$ last & - & 252) \\
\hline $\mathrm{Au}(\mathrm{III})$ & $\mathrm{Sb}(\mathrm{III})$ or $\mathrm{U}(\mathrm{VI})$ & $\begin{array}{l}\text { acetone- } \mathrm{CH}_{3} \mathrm{COOH}-\mathrm{C}_{4} \mathrm{H}_{9} \mathrm{OH}- \\
4 M \mathrm{HCl}(1: 1: 1: 1)\end{array}$ & - & paper & 270) \\
\hline $\mathrm{In}, \mathrm{Tl}^{+}$ & mutual & MEK-50\% HCI (1: 1$)$ & - & paper & 270) \\
\hline $\mathrm{Ce}^{3+}$ & $\mathrm{Pr}^{3+}$ or $\mathrm{Nd}^{3+}$ & $\begin{aligned} 0.005 M & \mathrm{HNO}_{3}+2 \% \mathrm{NH}_{4} \mathrm{Cl}- \\
0.5 \% \mathrm{HCl} & \end{aligned}$ & $\mathrm{Pr}$ or $\mathrm{Nd}-\mathrm{Ce}$ & - & 252) \\
\hline \multicolumn{6}{|c|}{ 25. Stannic tungstate $(\mathrm{SnW})$} \\
\hline $\mathrm{Ca}, \mathrm{Ba}$ & mutual & $4 M \mathrm{HCOOH}+4 M \mathrm{HCl}(8: 2)$ & $\mathrm{Ca}-\mathrm{Ba}$ & paper & 247) \\
\hline \multicolumn{6}{|c|}{ 26. Stannic selenite $(\mathrm{SnSe})$} \\
\hline $\mathrm{Fe}(\mathrm{III})$ & $\mathrm{Pb}, \mathrm{Sc}$ & $\begin{array}{l}0.01 M \mathrm{HNO}_{3}-6 \% \mathrm{NH}_{4} \mathrm{NO}_{3} \\
\text { in } 0.1 M \mathrm{NH}_{4} \mathrm{NO}_{3}\end{array}$ & Fe first & - & 264) \\
\hline $\mathrm{Cu}$ & $\begin{array}{l}\text { binary with } \mathrm{Ni}, \mathrm{Co} \text {, } \\
\text { Fe(III), Ga, } \ln \end{array}$ & $\begin{array}{l}0.01 M \mathrm{HNO}_{3}-6 \% \mathrm{NH}_{4} \mathrm{NO}_{3} \\
\text { in } 0.1 M \mathrm{HNO}_{3}\end{array}$ & Cud last & - & 264) \\
\hline \multicolumn{6}{|c|}{ 27. Chromium phosphate ( $\mathrm{CrP})$} \\
\hline $\mathrm{K}, \mathrm{Cs}^{+}$ & - & $\mathrm{H}^{+}$ & - & - & 342) \\
\hline $\mathrm{Rb}, \mathrm{Cs}$ & - & $\mathrm{H}^{+}$ & - & - & 342) \\
\hline $\mathrm{Rb}, \mathrm{Sr}$ & - & $\mathrm{H}^{+}$ & - & - & $342)$ \\
\hline $\mathrm{Ca}, \mathrm{Sc}$ & - & $\mathrm{NH}_{4}^{+}$ & - & - & $342)$ \\
\hline $99 \mathrm{mTc}$ & ${ }^{99} \mathrm{Mo}$ & $10^{-4} M \mathrm{NH}_{3}$ & Tc eluent & $\begin{array}{l}99 \mathrm{mTc} \text { generation } \\
1.2 \phi \times 30 \mathrm{~cm}\end{array}$ & 117) \\
\hline $\mathrm{Tc}^{4+}, \mathrm{Mo}^{6+}$ & - & $\mathrm{H}^{+}$ & - & - & 342) \\
\hline $\mathrm{Tc}^{4+}, \mathrm{Mo}^{6+}$ & - & $\mathrm{NH}_{4}{ }^{+}$ & - & - & $342)$ \\
\hline $\mathrm{Mn}^{2+}, \mathrm{Fe}^{3+}$ & - & $\mathrm{H}^{+}$ & - & - & 342) \\
\hline $\mathrm{Mn}^{2+}, \mathrm{Fe}^{3+}$ & - & $\mathrm{NH}_{4}^{+}$ & - & - & 342) \\
\hline $\mathrm{Fe}$ & Co & - & - & - & 152) \\
\hline $\mathrm{Co}, \mathrm{Fe}^{3+}$ & mutual & $0.1 M \mathrm{HCl}-2 M \mathrm{HCl}$ & $\mathrm{Co}-\mathrm{Fe}$ & - & 342) \\
\hline $\mathrm{Co}^{3+}, \mathrm{Fe}^{3+}$ & - & $\mathrm{H}^{+}$ & - & - & 342) \\
\hline $\mathrm{Co}^{2+}, \mathrm{Fe}^{3+}$ & - & $\mathrm{NH}_{4}{ }^{+}$ & - & 一 & 342) \\
\hline $\mathrm{Cd}^{2+}, \mathrm{In}^{3+}$ & - & $\mathrm{NH}_{4}^{+}$ & . - & - & 342) \\
\hline $113 \mathrm{mIn}$ & ${ }^{113} \mathrm{Sn}_{\mathrm{n}}$ & $1.5 M \mathrm{HCl}$ & In eluted & $\begin{array}{l}113 \mathrm{mIn} \text { generation } \\
1.2 \phi \times 30 \mathrm{~cm}\end{array}$ & 117) \\
\hline $\mathrm{Sn}^{2+}, \mathrm{In}^{3+}$ & - & $\mathrm{H}^{+}$ & - & - & $342)$ \\
\hline \multicolumn{6}{|c|}{ 28. Chromium tripolyphosphate (CrTrpP) } \\
\hline $\mathrm{Na}, \mathrm{K}, \mathrm{Rb}, \mathrm{Cs}$ & $\begin{array}{l}\text { mutual and other } \\
\text { divalent metals }\end{array}$ & $1 M \mathrm{HCl}$ & $\mathrm{Na}-\mathrm{K}-\mathrm{R} \cdot \mathrm{b}-\mathrm{Cs}$ & glass & $61)$ \\
\hline \multicolumn{6}{|c|}{ 29. Chromium molybdate ( $\mathrm{CrMo}$ ) } \\
\hline $\mathrm{Pb}$ & $\begin{array}{l}\text { binary with } \mathrm{Ni}, \mathrm{Co} \\
\mathrm{Mn}^{2+} \text { or } \mathrm{Cu}\end{array}$ & $\begin{array}{l}0.2 M \mathrm{NH}_{4} \mathrm{Cl}-1 M \mathrm{NH}_{4} \mathrm{Cl} \\
\text { in } 0.1 M \mathrm{HNO}_{3}\end{array}$ & $\mathrm{~Pb}$ last & $0.39 \mathrm{~cm} \phi$ & 258) \\
\hline \multicolumn{6}{|c|}{ 30. Phosphoantimonic acid (SbP) } \\
\hline alkalline earths & alkali metal & $\mathrm{HNO}_{3}$ or $\mathrm{HCl}(0.2 \sim 2 M)$ & 一 & - & 44) \\
\hline alkali metal & & & & & 157) \\
\hline lantanide & transition metal & & & & 44) \\
\hline
\end{tabular}




\begin{tabular}{|c|c|c|c|c|c|}
\hline Elements & Separation from & Eluent & Elution order & Note & ferences \\
\hline \multicolumn{6}{|c|}{ 31. Lead strontium hydroxyapatite (LSH) } \\
\hline $\mathrm{F}^{-}$ & $\mathrm{Al}$ & citrate soln. $(\mathrm{pH}=8 \sim 9)$ & & sepn. $30 \mathrm{~min}$ & 111) \\
\hline \multicolumn{6}{|c|}{ 32. Uranium hydrogen phospate (UHP) } \\
\hline Cs & $\mathrm{Ce}$ & - & - & - & 233) \\
\hline Cs & Co & - & - & - & 233) \\
\hline $\mathrm{Sr}$ & $\mathbf{Y}$ & - & - & - & 233) \\
\hline $\mathrm{Zn}$ & Co & - & - & - & 233) \\
\hline $\mathrm{Na}$ & $\mathrm{K}, \mathrm{Rb}, \mathrm{Cs}$ & $0.001 M \mathrm{NH}_{4} \mathrm{Cl}-0.1 M \mathrm{NH}_{4} \mathrm{Cl}$ & $\mathrm{Na}-\mathrm{K}, \mathrm{Rb}, \mathrm{Cs}$ & $0.3 \phi \times 7.2 \mathrm{~cm}$ & 233) \\
\hline \multicolumn{6}{|c|}{ 33. Antimonium 12-molybdophosphate (AMP) } \\
\hline $\mathrm{Na}, \mathrm{K}$ & mutual & $0.02 M \mathrm{NH}_{4} \mathrm{NO}_{3}-0.5 \mathrm{M} \mathrm{NH}_{4} \mathrm{NO}_{3}$ & $\mathrm{Na}-\mathrm{K}$ & \multicolumn{2}{|c|}{$1.0 \phi \times 6.8 \mathrm{~cm}$ on asbestos 304$)$} \\
\hline $\mathrm{Na}, \mathrm{K}$ & mutual & $0.01 M \mathrm{HNO}_{3}-0.25 \mathrm{M} \mathrm{NH}_{4} \mathrm{NO}_{3}$ & $\mathrm{Na}-\mathrm{K}$ & $\begin{array}{l}\text { on asbestos and glass. } \\
\text { wool }(1: 1)\end{array}$ & 94) \\
\hline $\mathrm{Na}, \mathrm{K}, \mathrm{Rb}, \mathrm{Cs}$ & mutual & $\mathrm{NH}_{4} \mathrm{NO}_{3}$ & $\mathrm{Na}-\mathrm{K}-\mathrm{Rb}-\mathrm{Cs}$ & - & 301) \\
\hline $\mathrm{Na}, \mathrm{K}, \mathrm{Rb}, \mathrm{Cs}$ & mutual & $0.1 M \mathrm{NH}_{4} \mathrm{NO}_{3}$ & $\mathrm{Na}-\mathrm{K}-\mathrm{Rb}-\mathrm{Cs}$ & TLC & 207) \\
\hline alkali metal & mutual & $0.1 \mathrm{M} \mathrm{HNO}_{3}+0.2 \mathrm{M} \mathrm{NH}_{4} \mathrm{NO}_{3}$ & $\mathrm{Na}, \mathrm{Li}-\mathrm{K} \cdot \mathrm{Cs}, \mathrm{Rb}$ & \multicolumn{2}{|c|}{$\begin{array}{l}\text { paper impegnated with } \\
\text { AMP sepn. Li-Na }(95 \% \\
\left.\mathrm{C}_{2} \mathrm{H}_{5} \mathrm{OH}\right) \mathrm{Rb}-\mathrm{Rs}(0.5 M) \\
\left.\mathrm{HNO}_{3}+3 M \mathrm{NH}_{4} \mathrm{NO}_{3}\right)\end{array}$} \\
\hline $\mathrm{Na}, \mathrm{K}, \mathrm{Rb}, \mathrm{Cs}, \mathrm{Tl}$ & mutual & $\begin{array}{c}5 M \mathrm{HNO}_{3}-3 M \mathrm{NH}_{4} \mathrm{NO}_{3} 0.05 M \\
\mathrm{Br}_{2} / 5 \% \mathrm{HBr}-12 M \mathrm{NH}_{4} \mathrm{NO}_{3}\end{array}$ & $\mathrm{Na}, \mathrm{K}-\mathrm{Rb}-\mathrm{Tl}-\mathrm{Cs}$ & on asbestos & 286) \\
\hline $\mathrm{Na}, \mathrm{Rb}$ & mutual & $0.01 M \mathrm{HNO}_{3}-5 \mathrm{M} \mathrm{NH}_{4} \mathrm{NO}_{3}$ & $\mathrm{Na}-\mathrm{Rb}$ & on asbestos & 93) \\
\hline $\mathrm{K}, \mathrm{Rb}$ & mutual & $0.2 M \mathrm{NH}_{4} \mathrm{NO}_{3}-3 M \mathrm{NH}_{4} \mathrm{NO}_{3}$ & $\mathrm{~K}-\mathrm{Rb}$ & $1.0 \phi \times 3.3 \mathrm{~cm}$ on asbestos & 304) \\
\hline $\mathrm{K}, \mathrm{Rb}$, Cs & mutual & $0.4 M \mathrm{NH}_{4} \mathrm{NO}_{3}+0.1 M \mathrm{HNO}_{3}$ & $\mathrm{~K}-\mathrm{Rb}-\mathrm{Cs}$ & paper & $338)$ \\
\hline $\mathrm{Rb}$, Cs & mutual & $4 M \mathrm{~N}_{4} \mathrm{NO}_{3}$-sat & $\mathrm{Rb}-\mathrm{Cs}$ & $1.4 \phi \times 8.9 \mathrm{~cm}$ on asbestos & $304)$ \\
\hline Cs & rain water & - & - & - & 113) \\
\hline Cs & reactor coolant & $\mathrm{BM}-2 \mathrm{M} \mathrm{HNO}_{3}-5 M \mathrm{NH}_{3}$ & Cs retained & $\begin{array}{l}\text { exchanger dissolved } \\
\text { with } \mathrm{NH}_{3}\end{array}$ & 228) \\
\hline Cs & soil & - & Cs retained & batch & 281) \\
\hline Cs & other & $\mathrm{HNO}_{3}$ & Cs retained & on $\mathrm{SiO}_{2}$ & 77) \\
\hline $\mathrm{Cs}, \mathrm{Sr}, \mathrm{Y}$, rare earth & fission product & $\begin{array}{l}\mathrm{BM}-0.01 M \mathrm{NO}_{3}-1 M \mathrm{NH}_{4} \mathrm{NO}_{3} \\
-1 M \mathrm{NH}_{4} \mathrm{NO}_{3}+1 M \mathrm{HNO}_{3} \text {-sat. } \\
\mathrm{NH}_{4} \mathrm{NO}_{3}\end{array}$ & $\begin{array}{l}\text { others-Sr-Y, rare } \\
\text { earth-Cs }\end{array}$ & $\begin{array}{l}0.9 \phi \times 5.0 \mathrm{~cm} \\
\text { on asbestos }\end{array}$ & 305) \\
\hline${ }^{137} \mathrm{Css}$ & acid soln. & $\mathrm{BM}$ & Cs retained & on $\mathrm{SiO}_{2}$ & 75) \\
\hline${ }^{137} \mathrm{Cs}$ & sea water & BM & Cs retained & on $\mathrm{SiO}_{2}$ & 315) \\
\hline${ }^{137} \mathrm{Ba}$ & ${ }^{137} \mathrm{Cs}$ & $0.1 M \mathrm{HCl}+0.1 M \mathrm{NH}_{4} \mathrm{Cl}$ & Ba eluted & ${ }^{137} \mathrm{Ba}$ generator & 225) \\
\hline $\mathrm{Th}, \mathrm{U}, \mathrm{Np}$ & fission product & - & - & - & 121) \\
\hline $\mathrm{U}, \mathrm{Np}(\mathrm{IV})$ & mutual & $0.2 M \mathrm{HF}-12 M \mathrm{HCl}$ & U-NP & $0.8 \phi \times 7 \mathrm{~cm}$ on asbestos & 122) \\
\hline $\mathrm{Np}(\mathrm{V}), \mathrm{U}, \mathrm{Th}$ & mutual & $\begin{array}{l}\mathrm{BM}-0.025 M \mathrm{HNO}_{3}-0.2 M \mathrm{HF} \\
\quad-8 M \mathrm{HNO}_{3}\end{array}$ & $\mathrm{~Np}(\mathrm{~V})-\mathrm{U}-\mathrm{Th}$ & $0.8 \phi \times 7 \mathrm{~cm}$ on asbestus & 122) \\
\hline $\mathrm{Np}(\mathrm{IV}, \mathrm{V}), \mathrm{U}, \mathrm{Th}$ & mutual & $\begin{array}{l}\mathrm{BM}-0.025 \mathrm{M} \mathrm{HNO}_{3}-0.2 M \mathrm{HF} \\
-12 \mathrm{M} \mathrm{HCl}\end{array}$ & $\mathrm{Ne}(\mathrm{V})-\mathrm{U}-\mathrm{Th}, \mathrm{Np}(\mathrm{IV})$ & $0.8 \phi \times 7 \mathrm{~cm}$ on asbestos & 122) \\
\hline $\mathrm{Rb}, \mathrm{Cs}$ & mutual & $1 M \mathrm{NH}_{4} \mathrm{NO}_{3}-\mathrm{IOM} \mathrm{NH}_{4} \mathrm{NO}_{3}$ & $\mathrm{Rb}-\mathrm{Cs}$ & $\begin{array}{l}1.2 \phi \times 3 \mathrm{~cm} \text { on asbestos } \\
\mathrm{AMP}+\mathrm{AWP}\end{array}$ & 198) \\
\hline \multicolumn{6}{|c|}{ 34. Ammonium 12 tungstophosphate (AWP) } \\
\hline alkali metal & mutual & $\begin{array}{l}0.4 M \mathrm{NH}_{4} \mathrm{NO}_{3}+0.4 M \mathrm{HNO}_{3} \\
\left(\mathrm{CH}_{3} \mathrm{OH}: \mathrm{H}_{2} \mathrm{O}=4: 1\right)\end{array}$ & $\mathrm{Li}-\mathrm{Na}-\mathrm{K}-\mathrm{Rb}-\mathrm{Cs}$ & paper & 80) \\
\hline $\mathrm{K}, \mathrm{Rb}, \mathrm{Cs}, \mathrm{Ag}, \mathrm{Tl}$ & mutual & - & - & $\begin{array}{l}\text { some with AMAs and } \\
\text { AWAs }\end{array}$ & $301)$ \\
\hline \multicolumn{6}{|c|}{ 35. Ammonium 12 silicotungstate $(\Lambda \mathrm{WSi})$} \\
\hline $\mathrm{UO}_{2}{ }^{2+}, \mathrm{Cs}$ & mutual & $0.03 \mathrm{M} \mathrm{HClO}_{4}$ & $\mathrm{Cs}-\mathrm{U}$ & paper impregnated with & 210) \\
\hline $\mathrm{UO}_{2}{ }^{2+}, \mathrm{Sr}, \mathrm{Y}^{3+}$ & mutual & $0.1 M \mathrm{HClO}_{4}$ & $\mathrm{Y}-\mathrm{U}-\mathrm{Sr}$ & paper impregnated with & 210) \\
\hline $\mathrm{UO}_{2}^{2+}, \mathrm{Co}$ & mutual & $0.01 M \mathrm{HClO}_{4}$ & Co $\mathrm{U}$ & paper impregnated with & 210) \\
\hline $\mathrm{UO}_{2}{ }^{2+}, \mathrm{Bi}^{3+}$ & mutual & $0.05 \mathrm{M} \mathrm{HClO}_{4}$ & $\mathrm{U}-\mathrm{Bi}$ & paper impregnated with & 210) \\
\hline $\mathrm{UO}_{2}{ }^{2+}, \mathrm{La}^{3+}$ & mutual & $0.03 \mathrm{M} \mathrm{HClO}_{4}$ & U-La & paper impregnated with & 210) \\
\hline $\mathrm{UO}_{2}{ }^{2+}, \mathrm{Eu}^{3+}$ & mutual & $0.01 M \mathrm{HClO}_{4}$ & $\mathrm{U}-\mathrm{Eu}$ & paper impregnated with & 210) \\
\hline \multicolumn{6}{|c|}{ 36. Thallium tungstophosphate (TIWP) } \\
\hline $\mathrm{Rb}, \mathrm{Cs}$ & mutual & $1 M \mathrm{NH}_{4} \mathrm{NO}_{3}-6 M \mathrm{NH}_{4} \mathrm{NO}_{3}$ & $\mathrm{Rb}-\mathrm{Cs}$ & on asbestos & 188) \\
\hline Cs & $\mathrm{Na}, \mathrm{K}$ & $\mathrm{BM}$ & Cs retained & micro amount $\mathrm{Na}, \mathrm{K}$ & 114) \\
\hline \multicolumn{6}{|c|}{ 37. Zinc ferrocyanide ( $\mathrm{ZnFC})$} \\
\hline $\mathrm{Na}, \mathrm{K}$ & mutual & $0.3 M \mathrm{HNO}_{3}-1 M \mathrm{NH}_{4} \mathrm{NO}_{3}$ & $\mathrm{Na}-\mathrm{K}$ & - & 184) \\
\hline $\mathrm{Na}, \mathrm{K}, \mathrm{Rb}, \mathrm{Cs}$ & mutual & $0.2 \mathrm{M} \mathrm{NH}_{4} \mathrm{NO}_{3}$ & $\mathrm{Na}-\mathrm{K}-\mathrm{Rb}$-Cis & TLC, with cellulose & 162) \\
\hline $\mathrm{Rb}, \mathrm{Cs}$ & mutual & $0.05 M \mathrm{NH}_{4} \mathrm{NO}_{3}-6 \mathrm{M} \mathrm{NH}_{4} \mathrm{NO}_{3}$ & $\mathrm{Rb}-\mathrm{Cs}$ & - & 184) \\
\hline $\mathrm{Rb}$, Cs & mutual & $4 M \mathrm{HNO}_{3}-6 M \mathrm{HNO}_{3}$ & $\mathrm{Rb}-\mathrm{Cs}$ & - & 184) \\
\hline Cs & rinsing water & $\mathrm{BM}-5 \mathrm{M} \mathrm{NH}_{4} \mathrm{NO}_{3}$ & Cs retained and eluted & - & 170) \\
\hline
\end{tabular}




\begin{tabular}{|c|c|c|c|c|c|}
\hline Elements & Separation from & Eluent & Elution order & Note & eferences \\
\hline $\mathrm{Rb}, \mathrm{Sr}, \mathrm{Ce}, \mathrm{Zr}, \mathrm{Cs}$ & fission product & $\begin{array}{l}\mathrm{BM}-0.3 \mathrm{M} \mathrm{NaNO}_{3}-0.6 M \mathrm{HNO}_{3}- \\
\quad 6 M \mathrm{HNO}_{3}\end{array}$ & $\begin{array}{l}\text { others-Ru, Sr, Ce, Zr, } \\
\text { Zr, Ce-Cs }\end{array}$ & $0.6 \mathrm{~cm} \phi, 0.3 \mathrm{~g}$ & 182) \\
\hline \multicolumn{6}{|c|}{ 38. Copper ferrocyanide (CuFC) } \\
\hline $\mathrm{CsCl}$ & $\mathrm{RbCl}$ & $1 M \mathrm{NaCl}$ & Cs retained & - & 297) \\
\hline Cs & waste water & $\mathrm{BM}\left(0.5 M \mathrm{H}^{+}\right)-5 M \mathrm{NH}_{4} \mathrm{NO}_{3}$ & Cs retained and eluted & - & 279) \\
\hline Cs & waste water & - & Cs retained & - & 115) \\
\hline Cs & aq. soln. & - & Cs retained & co-ppt & 103) \\
\hline Cs & sea water & $\begin{array}{l}\mathrm{BM}-\mathrm{HNO}_{3}, \mathrm{AgNO}_{3}, \mathrm{NaOH} \\
\quad \text { or } \mathrm{NH}_{4} \mathrm{OH}\end{array}$ & Cs relained and eluted & on Amberlite IRA-904 & $334)$ \\
\hline $\begin{array}{l}{ }^{90} \mathrm{Sr},{ }^{95} \mathrm{Zr},{ }^{95} \mathrm{Nb}, \\
{ }_{106} \mathrm{Ru},{ }^{44} \mathrm{Ce}\end{array}$ & mutual & $\mathrm{HCl}$ & - & on Amberlite IRA-904 & 70) \\
\hline${ }^{137} \mathrm{Ba}$ & ${ }^{137} \mathrm{Cs}$ & $\mathrm{H}_{2} \mathrm{O}$ & Ba eluted & $\begin{array}{l}137 \mathrm{Ba} \text { generator on } \\
\quad \text { resin } 0.9 \phi \times 10 \mathrm{~cm}\end{array}$ & 223) \\
\hline radioactive elements & waste water & - & radioactive retained & $\begin{array}{l}\text { ppt. method same } \\
\text { with NiFCN }\end{array}$ & 70) \\
\hline \multicolumn{6}{|c|}{ 39. Cobalt ferrocyanide (CoFC) } \\
\hline Cs & sea water & $\mathrm{BM}$ & Cs retained & on $\mathrm{SiO}_{2}$ & $315)$ \\
\hline${ }^{137} \mathrm{Cs}$ & waste water & $\mathrm{BM}-\mathrm{Th}$ or $\mathrm{Hg}(\mathrm{II})$ nitrate & Cs retained and eluted & - & 246) \\
\hline${ }^{137} \mathrm{Cs}$ & $\begin{array}{l}\text { waste water } \\
\text { or sea water }\end{array}$ & $\mathrm{BM}$ & Cs retained & $\begin{array}{l}\mathrm{K} \text { form } \mathrm{Sb} \text { retained but } \\
\text { eluted with } 0.1 M \mathrm{NH}_{3}\end{array}$ & 293) \\
\hline${ }^{139} \mathrm{Ba},{ }^{139} \mathrm{Cs}$ & waste soln. & $\begin{array}{c}\mathrm{BM}\left(\mathrm{NaCl} \text { or } \mathrm{NH}_{4} \mathrm{OH}\right)-1 M \\
\mathrm{KNO}_{3}-0.1 M \mathrm{Hg}\left(\mathrm{NO}_{3}\right)_{2}\end{array}$ & others-Ba-Cs & $\begin{array}{l}\mathrm{K} \text { form, exchanger } \\
\text { dissolved with } \mathrm{Hg}^{2+}\end{array}$ & 245) \\
\hline $\mathrm{Ag}$ & waste soln. & $\mathrm{BM}(\mathrm{pH} 1.7$ or neutral) & Ag retained & $\begin{array}{l}\mathrm{K} \text { form, exchanger } \\
\text { dissolved with KGN }\end{array}$ & $332)$ \\
\hline \multicolumn{6}{|c|}{ 40. Ferrous ferrocyanide ( $\mathrm{FeFC}$ ) } \\
\hline${ }^{137} \mathrm{Cs}$ & waste & $\mathrm{BM}\left(\mathrm{HNO}_{3}\right)$ & Cs retained & - & $335)$ \\
\hline $\begin{array}{l}{ }^{137} \mathrm{Cs},{ }^{90} \mathrm{Sr},{ }^{144} \mathrm{Ce}, \\
{ }^{95} \mathrm{Zr},{ }^{95} \mathrm{Hf},{ }^{95} \mathrm{Nb}, \\
{ }^{106} \mathrm{Ru}\end{array}$ & fission product & BM(oxalate soln.) & radionuclide retained & on Amberlite IRA-904 & $335)$ \\
\hline $137 \mathrm{~m} \mathrm{Ba}$ & ${ }^{137} \mathrm{Cs}$ & $0.001 M \mathrm{HCl}$ & Ba eluted & $137 \mathrm{~m} \mathrm{Ba}$ generator & $60)$ \\
\hline $\mathrm{Rb}, \mathrm{Cs}$ & mutual & $6 M \mathrm{NH}_{4} \mathrm{NO}_{3}-10 M \mathrm{HNO}_{3}$ & $\mathrm{Rb}-\mathrm{Cs}$ & $0.6 \phi \times 10 \mathrm{~cm}$ & 193) \\
\hline \multicolumn{6}{|c|}{ 41. Vanadium ferrocyanide (VFC) } \\
\hline${ }^{137} \mathrm{Cs}$ & fission product & $\mathrm{BM}\left(3 M \mathrm{HNO}_{3}\right)-10 M \mathrm{HNO}_{3}$ & Cs retained and eluted & $0.6 \phi \times 4 \mathrm{~cm}$ & 193) \\
\hline${ }^{137} \mathrm{Cs}$ & fission product & $\mathrm{BM}\left(3 M \mathrm{HNO}_{3}\right)-\mathrm{EDTA}$ & Cs retained & $\begin{array}{l}\text { exchanger dissolved } \\
\text { with EDTA }\end{array}$ & 195) \\
\hline \multicolumn{6}{|c|}{ 42. Stannic feerocyanide (SnFC) } \\
\hline $\mathrm{Ba}, \mathrm{La}$ & mutual & $\mathrm{H}_{2} \mathrm{O}-0.5 M \mathrm{NH}_{4} \mathrm{Cl}+0.1 M \mathrm{HCl}$ & $\mathrm{Ba}-\mathrm{La}$ & $0.5 \phi \times 4.9 \mathrm{~cm}$ & 127) \\
\hline $\mathrm{UO}_{2}{ }^{2+}, \mathrm{Th}^{4+}$ & mutual & $\mathrm{H}_{2} \mathrm{O}-0.5 \mathrm{M} \mathrm{NH}_{4} \mathrm{Cl}+0.1 M \mathrm{HCl}$ & $\mathrm{U}-\mathrm{Th}$ & $0.5 \phi \times 4.9 \mathrm{~cm}$ & 127) \\
\hline $\mathrm{Zr}^{4+}, \mathrm{Th}^{4+}$ & mutual & $\mathrm{H}_{2} \mathrm{O}-0.5 M \mathrm{NH}_{4} \mathrm{Cl}+0.1 M \mathrm{HCl}$ & $\mathrm{Zr}-\mathrm{Th}$ & $0.5 \phi \times 4.9 \mathrm{~cm}$ & 127) \\
\hline \multicolumn{6}{|c|}{ 43. Zirconium ferrocyanide ( $\mathrm{ZrFC})$} \\
\hline $\mathrm{Fe}, \mathrm{Co}, \mathrm{Zn}, \mathrm{Cs}, \mathrm{Zr}$ & sea water & $\mathrm{BM}(0.1 M \mathrm{HCl})-25 \%$ EDTA & metal retained & $\begin{array}{l}1.5 \phi \times 5 \mathrm{~cm} \text { exchanger } \\
\text { dissolved with EDTA }\end{array}$ & 163) \\
\hline $\mathrm{Ca}, \mathrm{Ba}$ & mutual & $\mathrm{H}_{2} \mathrm{O}-0.5 M \mathrm{NH}_{4} \mathrm{Cl}+0.1 M \mathrm{HCl}$ & $\mathrm{Ca}-\mathrm{Ba}$ & $0.5 \phi \times 5 \mathrm{~cm}$ & 128) \\
\hline $\mathrm{Th}^{4+}$ & $\mathrm{Zr}^{4+}$ or $\mathrm{UO}_{2}^{2+}$ & $\mathrm{H}_{2} \mathrm{O}-0.5 M \mathrm{NH}_{4} \mathrm{Cl}+0.1 M \mathrm{HCl}$ & Th- $\mathrm{Zr}$ or $\mathrm{U}$ & $0.5 \phi \times 5 \mathrm{~cm}$ & 128) \\
\hline $\mathrm{Zn}$ & Cd or Co or $\mathrm{Mn}^{2+}$ & $\mathrm{H}_{2} \mathrm{O}-0.5 \mathrm{M} \mathrm{NH}_{4} \mathrm{Cl}+0.1 M \mathrm{HCl}$ & $\mathrm{Cd}$ or $\mathrm{Co}$ or $\mathrm{Mn}-\mathrm{Zn}$ & $0.5 \phi \times 5 \mathrm{~cm}$ & 128) \\
\hline \multicolumn{6}{|c|}{ 44. Molybdenum ferrocyanide (MoFC) } \\
\hline Sr, Ce, Cs & sea water & $\begin{array}{c}\mathrm{BM}-0.1 M \mathrm{HNO}_{3}+1 M \mathrm{NH}_{4} \mathrm{NO}_{3} \\
-4 M \mathrm{HNO}_{3}+4 M \mathrm{NH}_{4} \mathrm{NO}_{3}\end{array}$ & $\mathrm{Sr}$, Ce-Cs & $1 \phi \times 10 \mathrm{~cm}$ & $160)$ \\
\hline \multicolumn{6}{|l|}{ 45. Other ferrocyanide } \\
\hline${ }^{137} \mathrm{Cs}$ & acid soln. & $\mathrm{BM}$ & Cs retained & supported on $\mathrm{SiO}_{2}$ & 75) \\
\hline Cs & radioactive effluents & - & Cs retained & on resin & 69) \\
\hline
\end{tabular}

BM : Breakthrough method; Paper : Paper impregnated with ion exchanger; TLC: Thin layer chromatography

有効であるほか，ストロンチウムと希土類元素の分離に 有効である151).

最近, 塩化スズ(IV), 硝酸, リン酸を含む溶液を還流 することによって結晶性 SnP が合成された 97)116)214)337). その組成は $\mathrm{ZrP}$ と同様 $\mathrm{Sn}\left(\mathrm{HPO}_{4}\right)_{2} \cdot \mathrm{H}_{2} \mathrm{O}$ を示し, 理論
的交換容量は式量から $6.08 \mathrm{meq} / \mathrm{g}$ となる. $\mathrm{pH}$ 滴定曲 線から求めた值はリチウムを除いて少なく約 $5 \mathrm{meq} / \mathrm{g}$ を 示し, $\mathrm{Cs}^{+}$ではイオンふるい効果と立体効果のため $\mathrm{pH}$ $=7$ で約 $1 / 3$ の交換容量を示した. $\mathrm{Li}^{+}$の場合，高い $\mathrm{pH}$ で $7.9 \mathrm{meq} / \mathrm{g}$ を示し二つ以上の交換基が存在する 
Table VIII Separation of one cation from numerous metal ions on stannic phosphate papers ${ }^{247}$ )

\begin{tabular}{|c|c|c|c|}
\hline Cation separated & Solvent system & Ions likely to interfere & Time \\
\hline $\mathrm{Au}^{3+}(1.00)$ from 39 metal ions & $\begin{array}{l}n \text {-Butanol-HCl-10\% } \mathrm{NH}_{4} \mathrm{Cl} \\
(7: 2: 1)\end{array}$ & $\begin{array}{l}\mathrm{Hg}_{2}^{2+}, \mathrm{Hg}^{2+}, \mathrm{Cu}^{2+}, \mathrm{Sb}^{3+}, \\
\mathrm{Sb}^{5+}, \mathrm{Zn}^{2+}, \mathrm{Sn}^{2+}\end{array}$ & $3 \sim 5.5 \mathrm{hr}$ \\
\hline $\mathrm{Sb}^{3+}(0.90)$ from 35 metal ions & $\begin{array}{l}n \text {-Butanol-HCl- } 10 \% \mathrm{NH}_{4} \mathrm{Cl} \\
\quad(7: 2: 1)\end{array}$ & $\begin{array}{l}\mathrm{Cu}^{+}, \mathrm{Hg}_{2^{2+}}, \mathrm{Hg}^{2+}, \mathrm{Sb}^{3+}, \\
\mathrm{Sb}^{5+}, \mathrm{Zn}^{2+}, \mathrm{Cd}^{2+}, \mathrm{Ga}^{3+}\end{array}$ & $3 \sim 3.5 \mathrm{hr}$ \\
\hline $\mathrm{Sb}^{5+}(1.00)$ from 37 metal ions & $n$-Butanol- $\mathrm{HNO}_{3}(8: 2)$ & $\mathrm{Hg}_{2}{ }^{2+}, \mathrm{Au}^{3+}, \mathrm{Mo}^{6+}, \mathrm{Sn}^{2+}$ & $\begin{array}{l}2.5 \mathrm{hr} \text { and } \\
5.5 \mathrm{hr} \text { for } 15 \mathrm{~cm}\end{array}$ \\
\hline $\mathrm{Pd}^{2+}(0.25)$ from 39 metal ions & $\begin{array}{l}n \text {-Butanol- } \mathrm{HNO}_{3}-\mathrm{H}_{2} \mathrm{O} \\
\quad(8: 1: 1)\end{array}$ & $\underset{\text { probably } \mathrm{As}^{3+}}{\mathrm{Hg}^{2+}}$ & $\begin{array}{l}2.5 \sim 3 \mathrm{hr} \text { and } \\
5 \sim 6 \mathrm{hr} \text { for } 15 \mathrm{~cm}\end{array}$ \\
\hline $\mathrm{Hg}^{2+}(0.89)$ from 34 metal ions & $2 N \mathrm{HCl}-4 N \mathrm{NaCl}(\mathrm{l}: 1)$ & $\begin{array}{c}\mathrm{Mo}^{6+}, \mathrm{Pb}^{2+}, \mathrm{Cu}^{+}, \mathrm{Hg}_{2^{2+}} \\
\mathrm{Zn}^{2+}, \mathrm{Bi}^{3+}, \mathrm{Ag}^{+}, \mathrm{Tl}^{+}\end{array}$ & $\begin{array}{l}35 \sim 40 \min \text { and } \\
50 \mathrm{~min} \text { for } 16 \mathrm{~cm}\end{array}$ \\
\hline $\mathrm{Pt}^{4+}(0.93)$ from 38 metal ions & $\begin{array}{l}0.05 \mathrm{~N} \mathrm{NaCl}-0.05 \mathrm{~N} \mathrm{HCl} \\
(1: 1)\end{array}$ & $\mathrm{Mo}^{6+}, \mathrm{Pb}^{2+}, \mathrm{Au}^{3+}, \mathrm{Se}^{4+}$ & $\begin{array}{l}20 \sim 25 \mathrm{~min} \text { and } \\
45 \sim 50 \mathrm{~min} \text { for } 15 \mathrm{~cm}\end{array}$ \\
\hline $\begin{array}{l}\mathrm{As}^{3+}(0.46) \text { or }(0.71 \sim 0.22) \text { from } \\
36 \text { metal ions }\end{array}$ & $\begin{array}{l}0.05 \mathrm{~N} \mathrm{NaCl}-0.05 \mathrm{~N} \mathrm{HCl} \\
(1: 1)\end{array}$ & $\begin{array}{l}\mathrm{K}^{+}, \underset{\mathrm{Sb}^{5+}}{\mathrm{Se}^{4+}, \mathrm{Hg}^{2+}} \mathrm{Pd}^{2+}, \mathrm{Mo}^{6+}, \mathrm{Au}^{3+} \\
\end{array}$ & $\begin{array}{l}20 \sim 25 \mathrm{~min} \text { and } \\
45 \sim 50 \mathrm{~min} \text { for } 15 \mathrm{~cm}\end{array}$ \\
\hline $\begin{array}{l}\mathrm{Cs}, \mathrm{Rb} \text { and } \mathrm{K} \\
\text { respectively) (0.61, } 0.62,0.65 \\
\text { from } 35 \text { metal ions }\end{array}$ & ${ }_{(1: 1)}^{1 N \mathrm{HNO}_{3}-2 \mathrm{M}\left(\mathrm{NH}_{4}\right)_{2} \mathrm{HPO}_{4}}$ & $\mathrm{Pd}^{2+}, \mathrm{Mo}^{6+}, \mathrm{Se}^{4+}, \mathrm{V}^{5+}$ & $\begin{array}{l}30 \sim 35 \mathrm{~min} \text { and } \\
50 \mathrm{~min} \text { for } 15 \mathrm{~cm}\end{array}$ \\
\hline
\end{tabular}

かもしれない. Table に示したように SnP を含浸させ た紙で金，アンチモン(III) やアンチモン(V) が多数の 元素から分離できたほか, Table VIII に示す分離例が 報告されている.

2.4.2 ヒ酸スズ(IV) (SnAs) 塩化スズ(IV) とヒ 酸水素二ナトリウム溶液を混合すると無定形の白色沈殿 が得られる. As/Sn は 1.84256)または 1.0268)を示し約 $1 \mathrm{meq} / \mathrm{g}$ 前後の交換容量をもっている. 吸着順序は調製 条件によって変わるが，いずれも $\mathrm{Cu}^{2+}$ に対してよく吸 着し，銅や鉄などが分離できるほか多量の他のイオンか ら $\mathrm{Pb}^{2+}, \mathrm{UO}_{2}^{2+}$ および $\mathrm{Cr}^{3+}$ が分離できる268).

TiAs の場合と同様に塩化スズ(IV), ヒ酸ナトリウム, 硝酸を含む溶液と加熱すると $\mathrm{ZrP}$ と同形の層間距離 $0.777 \mathrm{~nm}$ の $\mathrm{Sn}\left(\mathrm{HAsO}_{4}\right)_{2} \cdot \mathrm{H}_{2} \mathrm{O}$ が生成する ${ }^{97) 267)}$. 理論 的交換容量は $4.80 \mathrm{meq} / \mathrm{g}$ を示す. TiAs と同様にセシ ウムに対して部分的なイオンふるい効果がある.

2.4.3 アンチモン酸スズ $(\mathrm{IV})(\mathrm{SnSb}) \quad$ アンチモン 酸が 4 価金属と酸性塩を生成しそれが陽イオン交換性 を示すことは著者らが報告し, 主として Qureshi らに よって各種のアンチモン酸塩類のイオン交換性が研究さ れている4)261). $\mathrm{K}\left[\mathrm{Sb}(\mathrm{OH})_{6}\right]$ の溶液か塩化アンチモン (V) 水溶液に塩化スズ(IV) を加えて $\mathrm{pH}$ を調節すると $\mathrm{Sb} / \mathrm{Sn}$ が 1:4〜2:1 まで連続的に変わるゲル状物が得 られる.これを乾燥したものは酸やアルカリにきわめて 安定なガラス状イオン交換体である1)4)154)157). 交換容量 はアンチモンの含有量の増加とともに増大する. Qureshi らによると $\mathrm{Sb}-\mathrm{OH}$ 基が交換基であると推論してい る.しかしアンチモンをあまり多くとるとアンチモン酸 との混合物が得られるので注意しなければならない*.

*これは $700^{\circ} \mathrm{C}$ に加熱したのち $\mathrm{X}$ 線回折を行なう. アンチモン酸が混合していれば加熱することによっ $\tau \mathrm{Sb}_{6} \mathrm{O}_{13}$ の結晶ピークが現われる ( $\mathrm{R} 14$ 参照).
交換容量は約 $1 \mathrm{meq} / \mathrm{g}$ で $\mathrm{pH}$ に依存する $\mathrm{Sb} / \mathrm{Sn}=1: 1$ の交換体は酸性溶液中で $\mathrm{Sr}^{2+}, \mathrm{Ba}^{2+}, \mathrm{Ca}^{2+}$ および $\mathrm{Hg}^{2+}$ をよく吸着する。また, $\mathrm{Zr}^{4+}, \mathrm{Th}^{4+}, \mathrm{Hf}^{4+}, \mathrm{La}^{3+}, \mathrm{Ce}^{4+}$,

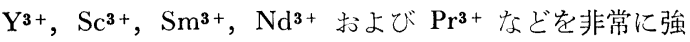
く吸着する. $\log K_{d}$ と $\mathrm{pH}$ の関係は $\mathrm{La}^{3+}$ に期待した 傾斜 +3 よりも小さく，次のような扠水分解をともなう と考えられた ${ }^{261)}$.

$$
\begin{aligned}
& \text { 加水分解反応 } \\
& \quad \mathrm{SnOHSbO}_{4} \stackrel{3 \mathrm{H}_{2} \mathrm{O}}{\rightleftarrows} \mathrm{Sn}(\mathrm{OH})_{4}+\mathrm{H}_{3} \mathrm{SbO}_{4} \\
& \quad 3 \mathrm{H}_{3} \mathrm{SbO}_{4}+2 \mathrm{La}^{3+} \rightleftarrows \mathrm{La}_{2}\left(\mathrm{HSbO}_{4}\right)_{3}+6 \mathrm{H}^{+} \\
& \text {イオン交換反応 } \\
& \quad 3 \mathrm{SnOHSbO}_{4}+\mathrm{La}^{3} \rightleftarrows\left(\mathrm{SnOSbO}_{4}\right)_{3} \mathrm{La}+3 \mathrm{H}^{+}
\end{aligned}
$$

これと類似した無定形 $\mathrm{ZrP} へ$ $\mathrm{UO}_{2}{ }^{2+}$ の吸着があ り, Veselý らは加水分解反応によって強い吸着が起こる と説明している291)， $\mathrm{Mg}^{2+}$ に対しての $K_{d}$ 値は非常に小 さく，多数のアルカリ土類金属や希土類元素から $\mathrm{Mg}^{2+}$ を選択的に除くことができる261).

2.4.4 モリブデン酸スズ(IV) (SnMo) 252) 269) 塩化 スズ(IV) とモリブデン酸ナトリウムの溶液の比を変え ることによって Sn/Mo 比が 1.99，1.70 と 1.90, 交換 容量がそれぞれ 0.54，0.71 と $0.73 \mathrm{meq} / \mathrm{g}$ の交換体が得 られる. カラムに適した粒状物が得られるが耐薬品性は Fig. 2-1 に示したように良好ではなく，水中に浸しても スズ(IV) やモリブデン(IV) が $1 \mathrm{mg} / 50 \mathrm{ml}$ 程度溶解す る.これは滴定曲線から弱酸性で, みかけ上一塭基性酸 を示すが，比較的溶液からも吸着する.このことはモり ブデン酸の酸性度がアンチモン酸やヒ酸よりも大きいた めと思われる. X 線回折や熱分析の結果から TiMo の 場合と同様の-O-Sn-O-Sn- 鎖にモリブデン酸が脱水縮 合した構造で，アンチモン酸塩と同様の $\mathrm{Mo}-\mathrm{OH}$ が交 換基となると考えられている. 分布係数の測定から各種 
Table IX Separation of one cation from numerous metal ions on stannic tungstate predicted by $R_{f}$ values $\left.{ }^{247}\right)$

\begin{tabular}{|c|c|c|c|}
\hline Metal ion separated & Solvent system & Ions which interfere & Time \\
\hline $\mathrm{Mg}^{2+}(0.78)$ from 37 cations & $1 N$ ammonium formate & $\mathrm{Pt}^{4+}, \mathrm{Pd}^{2+}, \mathrm{Au}^{3+}, \mathrm{K}^{+}, \mathrm{Rb}^{+}, \mathrm{Cs}^{+}$, and $\mathrm{Ca}^{2+}$ & $20 \mathrm{~min}$ \\
\hline $\mathrm{K}^{+}(0.76)$ from 37 cations & $1 N$ ammonium formate & $\mathrm{Pt}^{4+}, \mathrm{Pd}^{2+}, \mathrm{Au}^{3+}, \mathrm{Mg}^{2+}, \mathrm{Rb}, \mathrm{Cs}^{+}$, and $\mathrm{Ca}^{2+}$ & $20 \mathrm{~min}$ \\
\hline $\mathrm{Rb}^{+}(0.72)$ from 37 cations & $1 N$ ammonium formate & $\mathrm{Pr}^{4+}, \mathrm{Pd}^{2+}, \mathrm{Au}^{3+}, \mathrm{Mg}^{2+}, \mathrm{K}^{+}, \mathrm{Cs}^{+}$, and $\mathrm{Ca}^{2+}$ & $20 \mathrm{~min}$ \\
\hline $\mathrm{Cs}^{+}(0.61)$ from 36 cations & $1 N$ ammonium formate & $\mathrm{Pt}^{4+}, \mathrm{Pd}^{2+}, \mathrm{Au}^{3+}, \mathrm{Mg}^{2+}, \mathrm{K}^{+}, \mathrm{Rb}^{+}$, and $\mathrm{Ca}^{2+}$ & $20 \mathrm{~min}$ \\
\hline $\mathrm{Zr}^{4+}(0.06)$ from 25 cations & $\begin{array}{l}\text { Butanol }+50 \% \mathrm{HNO}_{3} \\
\quad(1: 1)\end{array}$ & $\begin{array}{l}\mathrm{Ag}^{+}, \mathrm{Hg}^{2+}, \mathrm{Bi}^{3+}, \mathrm{As}^{5+}, \mathrm{Sb}^{3+}, \mathrm{Co}^{2+}, \mathrm{Fe}^{2+}, \\
\mathrm{Fe}^{3+}, \mathrm{Se}^{4+}, \mathrm{Te}^{4+}, \mathrm{Mo}^{6+} \mathrm{Pt}^{4+}, \mathrm{Au}^{3+}, \mathrm{Ba}^{2+}, \\
\mathrm{Th}^{4+}, \mathrm{Ti}^{4+}, \mathrm{Ru}^{3+}, \text { and } \mathrm{Ir}^{4+}\end{array}$ & $2 \mathrm{hr}$ \\
\hline $\mathrm{Au}^{3+}(0.95)$ from 42 cations & Butanol $+50 \% \mathrm{HNO}_{3}(7: 3)$ & $\mathrm{Hg}^{2+}$ and $\mathrm{UO}_{2}^{2+}$ & $2 \mathrm{hr}$ \\
\hline $\mathrm{Hg}^{2+}(0.86)$ from 42 cations & Buranol $+50 \% \mathrm{HNO}_{3}(7: 3)$ & $\mathrm{Au}^{3+}$ and $\mathrm{UO}_{2}{ }^{2+}$ & $2 \mathrm{hr}$ \\
\hline $\mathrm{Pt}^{4+}(0.96)$ from 42 cations & $0.1 M$ ammonium carbonate & $\mathrm{Mo}^{6+}, \mathrm{Se}^{4+}, \mathrm{UO}_{2}{ }^{2+}$ & $20 \mathrm{~min}$ \\
\hline $\mathrm{Mo}^{6+}(0.94)$ from 42 cations & $0.1 \mathrm{M}$ ammonium carbonate & $\mathrm{Pt}^{4+}, \mathrm{Sc}^{4+}, \mathrm{UO}_{2}^{2+}$ & $20 \mathrm{~min}$ \\
\hline $\mathrm{UO}_{2}{ }^{2+}(0.52)$ from 39 cations & Butanol $+50 \% \mathrm{HNO}_{3}(7: 3)$ & $\mathrm{Pt}^{4+}, \mathrm{Pd}^{2+}, \mathrm{Bi}^{3+}, \mathrm{Be}^{2+}$, and $\mathrm{Au}^{3+}$ & $2 \mathrm{hr}$ \\
\hline $\mathrm{Ag}^{+}(0.90)$ from 32 cations & $\begin{array}{l}\text { Pyridine }+1 N \text { acetic acid } \\
\quad(1: 1)\end{array}$ & $\begin{array}{l}\mathrm{Hg}_{2}^{2+}, \mathrm{Hg}^{2+}, \mathrm{Cd}^{2+}, \mathrm{Cu}^{2+}, \mathrm{Ni}^{2+}, \mathrm{Cr}^{3+}, \mathrm{Zn}^{2+}, \\
\mathrm{UO}_{2}{ }^{2+}, \mathrm{Pd}^{2}, \mathrm{Au}^{3+}, \text { and } \mathrm{Ru}^{3+}\end{array}$ & $75 \mathrm{~min}$ \\
\hline $\mathrm{Se}^{4+}(0.92)$ from 33 cations & $\begin{array}{l}0.1 \mathrm{M} \text { ammonium tartrate } \\
\text { in } 4 M \mathrm{NH}_{4} \mathrm{OH}\end{array}$ & $\begin{array}{l}\mathrm{Ag}^{+}, \mathrm{Al}^{3+}, \mathrm{Cr}^{3+}, \mathrm{Ce}^{3+}, \mathrm{Ce}^{4+}, \underset{\mathrm{K}^{4+}}{\mathrm{Mo}^{6+}}, \mathrm{Rb}^{+}, \mathrm{Cs}^{3+}, \text { and } \mathrm{Pt}^{4+}\end{array}$ & $20 \mathrm{~min}$ \\
\hline
\end{tabular}

の分朔例が 期待される. カラム法によった分離例 ${ }^{252)}$ と 沪紙に含浸させた分離例 270 )がある.後者の分離例では有 機溶媒を加えることによっていっそう効果的に行なわれ る.

2.4.5 タングステン酸スズ $(\mathbf{I V})(\mathrm{SnW}) \quad$ SnMo と 類似した方法で調製され272)，W/Sn が3で SnMoより も加水分解や薬品に安定である.交換容量は〜 0.58meq/ $\mathrm{g}$ を示し，遷移金属イオンに対して選択性がある247).

沪紙に $\mathrm{SnW}$ を含浸させて $\mathrm{Mg}^{2+}, \mathrm{K}^{+}, \mathrm{Rb}^{+}$を 37 種 陽イオンから, $\mathrm{Au}^{3+}, \mathrm{Hg}^{2+}, \mathrm{Pt}^{4+} \mathrm{Mo}^{6+} 42$ 種陽イ オンから, $\mathrm{Zr}^{4+}, \mathrm{Se}^{4+}, \mathrm{UO}_{2}{ }^{2+}, \mathrm{Ag}^{+}, \mathrm{Cs}^{+}$を 25 種以 上の陽イオンから分離できた（Table IX).

2.4.6 セレン酸スズ $(\mathrm{IV})(\mathrm{SnSe})^{262)} 0.05 M$ 塩化 スズ(IV) と同濃度のセレン酸ナトリウム溶液を混合し て得られる. 同容積ずつ加え, $\mathrm{pH}=1$ としたものから 最も安定な交換体が得られ，50 $\mathrm{C}$ で乾燥したものは $0.75 \mathrm{meq} / \mathrm{g}$ の交換容量をもっている. $500^{\circ} \mathrm{C}$ で乾燥し たものでも $0.73 \mathrm{meq} / \mathrm{g}$ を示し，今までに合成されて無 機イオン交換体の 中で最も高い熱安定性をもっている 264). 無定形で $\mathrm{pH}$ 滴定曲線はみかけ上二塩基性酸を示 し, $(\mathrm{SnO})_{4}(\mathrm{OH})_{2}\left(\mathrm{SeO}_{3}\right) \cdot 6 \mathrm{H}_{2} \mathrm{O}$ の組成が考えられてい る. 4 価金属, 希土類, $\mathrm{Pb}^{2+}, \mathrm{Cu}^{2+}$ や $\mathrm{UO}_{2}{ }^{2+}$ に対して 強い吸着性を示し，その選択性は高温たとえば $\left(800^{\circ} \mathrm{C}\right)$ に加熱しても変化しない.

\section{5 七リウム塩類}

2.5・1 リン酸セリウム $(\mathbf{I V})(\mathbf{C e P})$ 無定形リン酸 セリウムがイオン交換性をもつことはVisser28)によっ て見いだされ，1967 年以来，König 178)179)および Alberli 23)2426)31) らによって研究されている. セリウム(IV) を
含む溶液にリン酸溶液を加えると CeP 交換体が得られ る. $\mathrm{P} / \mathrm{Ce}$ はその添加比によって变わり，1.03〜1.95を 与える. 硫酸イオン存在下で行なうと 2 2 $6 \%$ の硫酸イ オンがリン酸の代わりにはいる178).リン酸含量の高いほ ぞ，また $\mathrm{pH}$ が高いほどよく吸着し， $2.9 \mathrm{meq} / \mathrm{g}$ の交換 容量をもつが $200^{\circ} \mathrm{C}$ でその大部分を失う。選択性の順序 は $\mathrm{Cs}^{+}>\mathrm{Rb}^{+}>\mathrm{K}^{+}>\mathrm{Na}^{+}>\mathrm{Li}^{+}$の順である177)204).

Vissers ${ }^{328)}$ は CeP がマンガン(II) 溶液に浸すと明る い黄色から黒色に変わることを報告した. マンガンの正 確な酸化状態はまだよくわかっていないが，X 線分析 からリン酸セリウム(III) の回折が得られたことから次 のような電子交換反応が起こったものと考えられた.

$$
\begin{aligned}
& 2 \mathrm{Ce}^{\mathrm{IV}}(\mathrm{OH})_{8}\left(\mathrm{H}_{2} \mathrm{PO}_{4}\right)_{4}+3 \mathrm{Mn}^{2+} \longrightarrow \\
& \mathrm{Ce}_{3}{ }^{\mathrm{IV}}(\mathrm{OH})_{8} \mathrm{Mn}^{\mathrm{II}}\left(\mathrm{HPO}_{4}\right)_{2}\left(\mathrm{PO}_{4}\right)_{2}+6 \mathrm{H}^{+} \\
& \mathrm{Ce}_{3}{ }^{\mathrm{III}}(\mathrm{OH})_{8} \mathrm{Mn}^{\mathrm{III}}\left(\mathrm{HPO}_{4}\right)_{2}\left(\mathrm{PO}_{4}\right)_{2}
\end{aligned}
$$

また I-でも還元される204).

$$
\begin{aligned}
& 2 \mathrm{Ce}^{\mathrm{IV}}(\mathrm{OH})_{8}\left(\mathrm{H}_{2} \mathrm{PO}_{4}\right)+9 \mathrm{I}^{-} \rightleftarrows \\
& \quad 2 \mathrm{Ce}^{\mathrm{IV}}(\mathrm{OH})_{5}\left(\mathrm{H}_{2} \mathrm{PO}_{4}\right)_{4}+3 \mathrm{I}^{-}+6 \mathrm{OH}^{-}
\end{aligned}
$$

微結晶 $\mathrm{CeP}$ は硫酸セリウム $(\mathrm{IV})$ を $10 M$ リン酸溶液 に溶解し一度沸騰させたのち $80^{\circ} \mathrm{G}$ に冷却すると得ら れる. $\mathrm{P} / \mathrm{Ce}$ は 1.5 を示し, $(\mathrm{Ce}-\mathrm{O}-\mathrm{Ce})\left(\mathrm{HPO}_{4}\right)_{3} \cdot \mathrm{H}_{2} \mathrm{O}$ の組成をもつと考えられ交換容量は $\mathrm{pH} 1.51$ で 0.49 , $\mathrm{pH} 2.59$ で $0.87 \mathrm{meq} / \mathrm{g}$ を示す24)178). 吸着性はトレー ーサ量から 銀>ナトリウム>セシウムの順となる.

繊維状 $\mathrm{CeP}$ は $6 M$ リン酸に $0.5 M$ 硫酸 $-0.05 M$ 硫酸 セリウム (IV) を滴下し $94^{\circ} \mathrm{C} \pm 4^{\circ} \mathrm{C}$ に, $4 \mathrm{hr}$ 保つと得 られる. $\mathrm{PO}_{4} / \mathrm{Ce}$ は 1.98 で $\mathrm{Ce}\left(\mathrm{HPO}_{4}\right)_{2} \cdot \mathrm{H}_{2} \mathrm{O}$ に近い 組成をもつ. 無定形 $\mathrm{CeP}$ に比べ加水分解に安定で, 交 換容量も理論的交換容量 $(5.2 \mathrm{meq} / \mathrm{g})$ に近い $4.6 \mathrm{meq} /$ 
g が得られた.これは support-free の CeP sheet を作 成することができ， $1 M$ 過塩素酸を展開郕として $\mathrm{Li}^{+}$ $\mathrm{Na}^{+}-\mathrm{K}+, \mathrm{Ni}^{2+}-\mathrm{Ag}^{+}-\mathrm{Tl}+$ や $\mathrm{Co}^{2+}-\mathrm{Eu}^{2+}-\mathrm{Fe}^{2+}$ のペー パークロマトグラフ分離に成功している36).

結晶性リン酸一硫酸セリウム（CePS）は硫酸を含む溶 液から得られたものは多少なりとも $\mathrm{SO}_{4}{ }^{2-}$ を含み $\mathrm{Ce}_{2} \mathrm{O}$ $\left(\mathrm{HPO}_{4}\right)_{3-x}\left(\mathrm{SO}_{4}\right)_{x} \cdot 4 \mathrm{H}_{2} \mathrm{O}$ の組成をもち $\mathrm{Ce}: \mathrm{P}: \mathrm{S}$ を 最高 $2: 1: 2$ まですることができる172). $\mathrm{SO}_{4}$ の含量の 増加とともに交換容量が減少する．しかしながら Ce : $\mathrm{P}: \mathrm{S}$ が 2:2:1のものは物理的に安定でイオン交換体 としてすぐれた機械的強度をもっている. これは $\mathrm{Ag}^{+}$ や $\mathrm{Na}^{+}$が交換しても結晶構造を変えず一種のゼオライ 卜構造をもつと考元られる. 吸着の順序は $\mathrm{Na}^{+}>\mathrm{Ag}^{+}>$ $\mathrm{Sr}^{2+}>\mathrm{Ba}^{2+}>\mathrm{Cs}^{+}>\mathrm{Ca}^{2+}$ で, $\mathrm{Be}^{2+}, \mathrm{Co}^{2+}, \mathrm{Fe}^{3+}$ や $\mathrm{Y}^{3+}$ はほとんど吸着せず立体効果のほかにイオンふるい効果 も認められる. すなわち， $0.6 \mathrm{~nm}$ の有効イオン半径を もったイオンのみ交換体の入口にはいることができると 推論した ${ }^{26)}$.

\subsection{2 ヒ酸セリウム $(\mathrm{IV})(\mathrm{CeAs}) \quad 0.2 M$ 硫酸セリ} ウム $(\mathrm{IV})$ の $0.5 M$ 硫酸溶液に $6 M$ 七酸 $+0.5 M$ 硫酸 溶液を加え沸点で 100 200 hr 還流して得られる. Ce $\left(\mathrm{HAsO}_{4}\right)_{2} \cdot \mathrm{H}_{2} \mathrm{O}$ の組成をもち，理論的交換容量は 4.38 $\mathrm{meq} / \mathrm{g}$ で $\mathrm{Li}^{+}$と $\mathrm{Na}^{+}$について得られた〜 $4.35 \mathrm{meq} / \mathrm{g}$ とほぼ一致する.しかしながら $\mathrm{K}+$ については部分的 交換が起こり Cs+についてはほとえど交換しない。し かし低い $\mathrm{pH}(<5)$ では $\mathrm{K}^{+}>\mathrm{Na}^{+}>\mathrm{Li}^{+}$の順となる. $\alpha-\mathrm{ZrP}$ の層状構造と類似していると考えられ層間距離 は $0.91 \mathrm{~nm}$ を示し, $\mathrm{Li}^{+}$や $\mathrm{Na}^{+}$の交換の程度に応じ て連続的に層間が大となる. $\mathrm{Li}^{+}-\mathrm{H}^{+}$交換では非常によ い可逆的交換が起こり, $\mathrm{Na}^{+}-\mathrm{H}^{+}$交換では非常にわず かの hysteresis がある. $\mathrm{K}^{+-} \mathrm{H}^{+}$交換では顕著な hysteresis を描くが，水素形にもどした CeAs のX 線回折図 形ははじめの水素形とほとえど変わらない.このことは 他の $\mathrm{ZrP}$ や $\mathrm{ZrAs}$ で $\alpha$-から $\theta-\mathrm{ZrP}$ 型に変わる挙動と は明らかに異なっている。

2.5.3 タングステン酸セリウム $(\mathrm{IV})(\mathrm{CeW})^{314)}$ 硝 酸セリウム $(\mathrm{IV})$ アンモニウム溶液とタングステン酸ナ トリウムを種々の濃度にして加え $\mathrm{pH}$ は 1 0 に調節す ると $\mathrm{Ce} / \mathrm{W}$ が 0.49 0.57 の黄色 $\mathrm{CeW}$ が得られる. 交換容量は $0.4 \sim 0.89 \mathrm{meq} / \mathrm{g}$ を示し, $W$ の含有量が多 くなるに従い交換容量が大となる. マク口量の吸着順序 は $\mathrm{Ba}^{2+}>\mathrm{NH}_{4}{ }^{+} \geq \mathrm{K}^{+} \geq \mathrm{Na}^{+}>\mathrm{Ca}^{2+}>\mathrm{Li}^{+}$を示し, ミクロ 量では遷移金属元素について $\mathrm{Co}^{2+}>\mathrm{Cu}^{2+}>\mathrm{Ni}^{2+}>\mathrm{Zn}^{2+}$ $>\mathrm{Cd}^{2+}>\mathrm{Mn}^{2+}$ となっている. 特に $\mathrm{Tl}+$ や $\mathrm{Hg}^{2+}$ に ついて高い吸着性を示し $\mathrm{Cd}^{2+}, \mathrm{Pb}^{2+}, \mathrm{Zn}^{2+}$ から $\mathrm{Hg}^{2+}$
を $0.5 \phi \times 5.0 \mathrm{~cm}$ の小カラムで分離できた ${ }^{314)}$.

\section{6 トリウム塩類}

2.6.1 リン酸トリゥム $(\mathbf{T h P})^{18)} \quad \mathrm{ZrP}$ と同様に種 種の $\mathrm{P} / \mathrm{Th}$ をもつものが得られる. $100^{\circ} \mathrm{C}$ で $40 \mathrm{hr}$ 還 流すると. 繊維状 $\mathrm{CeP}$ と同様な $\mathrm{ThP}$ が得られ support free のイオン交換 sheet が得られる. 交換容量は Th $\left(\mathrm{HPO}_{4}\right)_{2} \cdot 3 \mathrm{H}_{2} \mathrm{O}$ の交換容量にあたる $3.7 \mathrm{meq} \mathrm{Na}+/ \mathrm{g}$ を示した。

2.6.2 ヒ酸トリウム $(\mathbf{T h A s})$ 硝酸トリウムの硝酸 溶液に $5 M$ の七酸溶液を加えて，3〜4 日間還流すると 微結晶が生成し $300 \mathrm{hr}$ 後にあまり変わらなくなる. 化 学分析の結晶 As/Th が 2.03 の倠が得られ ${ }^{30)}$. X 線回 折の結果から層間距離 $0.705 \mathrm{~nm}$ を示した.この組成 は $\mathrm{Th}\left(\mathrm{HAsO}_{4}\right)_{2} \cdot \mathrm{H}_{2} \mathrm{O}$ と考えられ, 滴定曲線の結果から 一塩基性酸を示した. $\mathrm{Na}^{+}, \mathrm{K}^{+}, \mathrm{Cs}^{+}$などはほとんど 吸着せずリチウムのみが吸着する，吸着したものの組成 は $\mathrm{Th}\left(\mathrm{Li}_{0.8} \mathrm{H}_{0.2} \mathrm{AsO}_{4}\right) \cdot 0.2 \mathrm{H}_{2} \mathrm{O}^{*}$ を示し, 無水の $\mathrm{Li}^{+}$ によって $\mathrm{H}^{+}$(水和していると考えられる) を交換した ことになる．この交換は hysteresis が顕著ではないが $\mathrm{Th}\left(\mathrm{HAsO}_{4}\right) \cdot \mathrm{H}_{2} \mathrm{O}$ から $\mathrm{Th}\left(\mathrm{LiPO}_{4}\right)_{2}$ への相転位による もので水素形とりチウム形の結晶構造がきわめて類似し ているために小さい hysteresis を示すと説明した ${ }^{30)}$. こ のようなイオンふるい効果を利用して $50 \mathrm{ml}$ 中に 1.58 meq の $\mathrm{Li}^{+}$と $13 \mathrm{meq} の \mathrm{Na}^{+}$を含む溶液に $0.5 \mathrm{~g}$ の ThAs を加えて 5 日間振とうした結果, $\mathrm{Li}^{+}$が $1.44 \mathrm{meq}$ 吸着され， $\mathrm{Na}^{+}$の吸着は $<0.01 \mathrm{meq}$ であった ${ }^{30)}$.

\section{7 クロム塩類}

2.7.1 リン酸クロム $(\mathbf{C r P})$ 調製条件によって P/ Cr 比が $0.6 \sim 1.0 \mathrm{meq} の$ 多塩基性酸のゲル状物が得ら れ, $\mathrm{Cr}_{2} \mathrm{O}_{2} \mathrm{HPO}_{4}, \mathrm{Cr}_{2} \mathrm{O}\left(\mathrm{HPO}_{4}\right)_{2}{ }^{309}$ または $\left.\mathrm{CrPO}_{4}{ }^{307}\right)$ と いう化学式で与えられる.最高の交換容量は $5.9 \mathrm{meq} / \mathrm{g}$ を示し，吸着イオンのイオン半径の増大とともに減少す る. 水素形での選択性は $\mathrm{Na}^{+} \geq \mathrm{K}+\geq \mathrm{Rb}^{+}>\mathrm{Cs}^{+}$の順で あり，アンモニウム形からは $\mathrm{Na}^{+}>\mathrm{K}^{+}>\mathrm{Cs}^{+} \geq \mathrm{Rb}^{+}$を 示す309)342). Table VII に示したようにアルカリ金属や 遷移金属イオンの分離が行なわれた.

2.7.2 トリポリリン酸クロム(III), (CrTriP) ト リポリリン酸ナトリウム溶液に種々の濃度の $\mathrm{CrCl}_{3} \cdot 6 \mathrm{H}_{2}$ $\mathrm{O}$ の溶液を加えると緑色ガラス状の交換体が得られる. $\mathrm{P} / \mathrm{Cr}$ は 2.4861)または 1.30〜1.6513)の值が報告されて

* Veselý らの総説 Talanta, 19, 246(1972) でTh(LiAs $\left.\mathrm{O}_{4}\right)_{2} \cdot \mathrm{H}_{2} \mathrm{O}$ が存在すると書いてあるのは誤まりと 思われる. 
いる. $\mathrm{Cr}_{5}\left(\mathrm{P}_{3} \mathrm{O}_{10}\right)_{3} \cdot x \mathrm{H}_{2} \mathrm{O}$ とすると 1.8 であるので後者 のほうがより近い值を示す．交換容量は交換イオンの種 類（たとえば $\mathrm{Na}^{+}$と $\mathrm{Ba}^{2+}$ )， $\mathrm{pH}$ および調製条件によ って著しく異なる.

$\mathrm{K}^{+}, \mathrm{Rb}^{+}$や $\mathrm{Cs}^{+}$では実験誤差範囲内で一定であり， その吸着量は（）内を $\mathrm{pH}$ とすると $0.51 \pm 0.01(2.0)$, $1.69 \pm 0.02(5.0), 2.89 \pm(8.0), 4.53 \pm 0.03(12)$ とな り, pH 飛躍や plateau を示さない多䘏基性酸の曲線を 示す13)62)

この交換体の特徵はアルカリ金属にのみ選択的であ り，他の 2 仳金属や遷移金属イオンはほとんど吸着せ ず，アルカリ金属イオンが吸着する $\mathrm{pH} 2$ 3 では次の ような金属が 25〜250 倍のモル比存在しても影響しな い.すなわち $10^{-3} \mathrm{~mol} / l$ の $\mathrm{Cs}^{+}, \mathrm{Rb}^{+}$や $\mathrm{Na}^{+}$の $10 \mathrm{~m} l$ と $0.05 M$ のニッケル，ストロンチウム，バリウム，イ ンジウム, 鉄(III), クロム(III) の塩化物や銅 $(\mathrm{II})$, 亜 鉛, コバルト(II), マンガン (II), マグネシウム, トリ ウム (IV) の硝酸塩溶液の $10 \mathrm{~m} l$ の混合液からアルカリ 金属のみを選択的に分離することができた.さらに $\mathrm{Na}^{+}$ $\mathrm{K}^{+}-\mathrm{Rb}^{+}-\mathrm{Cs}^{+}$の分離係数は $\alpha_{\mathrm{Na}}^{\mathrm{K}}=8.4 \pm 0.3 ， \alpha_{\mathrm{K}}^{\mathrm{Rb}}=2.2$ $\pm 0.1 ， \alpha_{\mathrm{Rb}}^{\mathrm{Cs}}=4.75 \pm 0.10$ を示し， $2 \mathrm{~g}$ のカラムを用い て $1 M$ 塩酸で分離できた62)。このようなアルカリ金属イ オンの特異的選択性は添加比によっても異なり, $\mathrm{P} / \mathrm{Cr}$ が3で調製したものは $\mathrm{Co}^{2+}, \mathrm{Zn}^{2+}, \mathrm{Ce}^{3+}$ や $\mathrm{Ba}^{2+} な$ どもよく吸着するが $\mathrm{P} / \mathrm{Cr}$ が 1.2 2.4 では遷移金属イ オンの $K_{d}$ が小さくなる. 特に乾燥条件が重要であるよ うに思われ, 室温で真空にしたデシケーター中に放置し ても変化があり，選択性が増大する13)．200～ $280^{\circ} \mathrm{C}$ で リン酸中で塩化クロム(III) を蒸発させたものは $\mathrm{H}_{2} \mathrm{Cr}$ $\mathrm{P}_{3} \mathrm{O}_{10} \cdot 2 \mathrm{H}_{2} \mathrm{O}$ が生成し $\mathrm{Ag}+$ に対して高い選択性がある. $\mathrm{K}+$ の交換では $\mathrm{K}_{2} \mathrm{CrP}_{3} \mathrm{O}_{10}$ となり無水の形が生成する. IR スペクトルの解析から $2 \mathrm{H}_{2} \mathrm{O}$ は $\mathrm{H}_{3} \mathrm{O}^{+}$と $\mathrm{OH}-に$ 解離している.

2.7.3 他のクロム塩 ${ }^{258)}$ 多く酸性塩と類似した方
法でヒ酸クロム $(\mathrm{CrAs})$, アンチモン酸クロム $(\mathrm{CrSb})$, モリブデン酸クロム (CrMo) やタングステン酸クロム が調製され，そのイオン交換性が Qureshi らによって 比較された. 安定性や分布係数の比較を Table X およ び Table XI に示す. CrSb の分布係数は非常に大き く， CrW や CrMo は一般に小さい. しかしながら $\mathrm{Rb}^{2+}$ や $\mathrm{Th}^{4+}, \mathrm{ZrO}^{2+}$ や $\mathrm{HfO}^{2+}$ などの 4 価金属イ オンに対して高い選択性をもち, $\mathrm{Ni}^{2+}-\mathrm{Pb}^{2+}, \mathrm{Co}^{2+}$ $\mathrm{Pb}^{2+}, \mathrm{Mn}^{2+-} \mathrm{Pb}^{2+}$ や $\mathrm{Cu}^{2+-} \mathrm{Pb}^{2+}$ を $2 \%$ 以内の誤差 で CrMo カラムで分離できた。

\section{8 他の酸性塩}

アルミニウム ${ }^{169)}$ および鉄(III) ${ }^{63)}$ トリポリリン酸，ピ ロリン酸鉄(III) (FePyroP)， バナジン酸アルミニウム $(\mathrm{AlV})^{63)}$ ，酸性リン酸ウラン $(\mathrm{UP})^{233)}$ ，テルル酸ビスマ ス, アンチモン酸タンタル $(\mathrm{TaSb})^{275)}$ やリン酸タンタ ル $(\mathrm{TaP})^{187) 226) 227)}$ がある.

比較的よく研究されているのは UP, TaSb, TaP で ある. UP230)232)317)318) は $\mathrm{NH}_{4}$ に対して強い吸着性を 示しその $\mathrm{NH}_{4}+$ 形は $\mathrm{Th}^{4+}, \mathrm{Pu}^{4+}$ や $\mathrm{Zr}^{4+}$ に強い選択 性がある.しかしながらこれらの吸着は沈殿機構に基づ くものと考えられている. カリウムールビジウムーセシウ ムの分離は不可能であったが，Table VII に示したよ うないくつかの分離に成功した ${ }^{233)}$.

$\mathrm{TaSb}$ は，無定形で $\mathrm{Sb} / \mathrm{Ta}$ が 1.3 で交換容量 〜 1.0 $\mathrm{meq} / \mathrm{g}$ をもつうすいピンク色をした交換体で比較的低 い $\mathrm{pH}$ からも高い $K_{d}$ 值をもち, $\mathrm{VO}^{2+}-\mathrm{Fe}^{3+}-\mathrm{Th}^{4+}$ や $\mathrm{VO}^{2+}-\mathrm{Al}^{3+-} \mathrm{Ti}^{4+}$ などが分離できた ${ }^{251)}$.

$\mathrm{TaP}$ は塩化タンタルの水溶液にリン酸を加えて還流 して得られる. 生成物は無定形で $\mathrm{P} / \mathrm{Sb}=0.88$ を示し カラム法による交換容量は $1.06 \mathrm{meq} \mathrm{Na}^{+} / \mathrm{g}$ および $1.26 \mathrm{meq} \mathrm{K}+/ \mathrm{g}$ であった. この交換体の特長は $\mathrm{Li}^{+}$と $\mathrm{Na}^{+}$に選択的であり， $\alpha_{\mathrm{Na}}^{\mathrm{K}}$ は 25 を示し $\mathrm{Li}^{+}, \mathrm{Na}^{+}$と カリウムールビジウムーセシウムの群分離は非常に容易に

Table X Comparison of $\mathrm{Cr}(\mathrm{III}), \mathrm{Sn}(\mathrm{IV})$ and $\mathrm{Ti}(\mathrm{IV})$ ion-exchangers $\left.{ }^{258}\right)$

\begin{tabular}{|c|c|c|c|}
\hline Property & Sequence of chromium (III) exchangers & Sequence of tin (IV) exchangers & $\begin{array}{c}\text { Sequence of titanium(IV) } \\
\text { exchangers }\end{array}$ \\
\hline Stability in water & $\mathrm{CrMo}>\mathrm{CrW}>\mathrm{CrOH}>\mathrm{CrAs}>\mathrm{CsSb}$ & $\mathrm{SnSb}>\mathrm{SnW}>\mathrm{SnAs}>\mathrm{SnMo}$ & TiW $\sim$ TiSb $>$ TiAs $>$ TiMo \\
\hline Stability in $\mathrm{HNO}_{3}$ & $\mathrm{CrW}>\mathrm{CsSb}>\mathrm{CrAs} \sim \mathrm{CrMo}>\mathrm{CrOH}$ & $\mathrm{SnW}>\mathrm{SnSb}>\mathrm{SnAs}>\mathrm{SnMo}$ & TiW $>$ TiSb $>$ TiMo $>$ TiAs \\
\hline Ion uptake & $\mathrm{CrSb}>\mathrm{CrOH}>\mathrm{CrAs}>\mathrm{CrMo}>\mathrm{CrW}$ & $\mathrm{SnSb}>\mathrm{SnMo}>\mathrm{SnW}>\mathrm{SnAs}$ & TiSb $>$ TiW $>$ TiAs $>$ TiMo \\
\hline $\begin{array}{l}\text { Thermal stability on } \\
\text { basis of ion-excha } \\
\text { capacity }\end{array}$ & $\mathrm{CrSb}>\mathrm{CrAs}>\mathrm{CrW}>\mathrm{CrMo}>\mathrm{CrOH}$ & SnAs $>$ SnSb $>$ SnW $>$ SnMo & TiAs $>$ TiW $>$ TiMo \\
\hline $\begin{array}{l}\text { Cation-exchange car } \\
\text { at neutral } \mathrm{pH}\end{array}$ & $\mathrm{CrAs}>\mathrm{CrSb} \sim \mathrm{CrW}>\mathrm{CrMo}>\mathrm{CrOH}$ & $\mathrm{SnAs}>\mathrm{SnMo}>\mathrm{SnSb}>\mathrm{SnW}$ & TiAs $>$ TiMo $>$ TiW $>$ TiSb \\
\hline
\end{tabular}

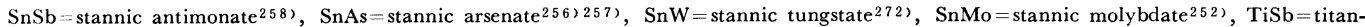
ium antimonate ${ }^{259}$ ), $\mathrm{TiAs}=$ titanium $_{\text {arsenate }}{ }^{263}$ ), $\mathrm{TiW}=$ titanium tungstate $^{249)}$, and $\mathrm{TiMo}=$ titanium molybdate $^{266}$ ) 
Table XI Distribution coefficients of metal ions on hydroxide, arsenate, antimonate, molybdate and tungstate of chromium(III) at $33^{\circ} \mathrm{C}_{ \pm} 1^{\circ} \mathrm{C}^{258}$ )

\begin{tabular}{|c|c|c|c|c|c|c|}
\hline \multirow{2}{*}{ Cations } & \multirow{2}{*}{$\begin{array}{c}\text { Ionic radius } \\
(A)\end{array}$} & \multicolumn{5}{|c|}{$K_{d}$ values $(\mathrm{ml} / \mathrm{g})$} \\
\hline & & $\mathrm{CrOH}$ & CrAs & $\mathrm{CrSb}$ & CrMo & CrW \\
\hline $\mathrm{Mg}^{2+}$ & 0.65 & 3 & 0 & $9.0 \times 10^{2}$ & 0 & 0 \\
\hline $\mathrm{Ca}^{2+}$ & 0.99 & 0 & 3 & $9.0 \times 10^{2}$ & 0 & 0 \\
\hline $\mathrm{Sr}^{2+}$ & 1.13 & 13 & 3 & $46 \times 10^{3}$ & 6 & 6 \\
\hline $\mathrm{Ba}^{2+}$ & 1.35 & $1.0 \times 10^{2}$ & 37 & $11 \times 10^{3}$ & 48 & 48 \\
\hline $\mathrm{Ni}^{2+}$ & 0.69 & 11 & 5 & $5.2 \times 10^{3}$ & 0 & 0 \\
\hline $\mathrm{Co}^{2+}$ & 0.72 & 19 & 23 & $11 \times 10^{3}$ & 7 & 5 \\
\hline $\mathrm{Cu}^{2+}$ & 0.96 & $9.7 \times 10^{2}$ & 40 & $8.3 \times 10^{3}$ & 2 & 2 \\
\hline $\mathrm{Mn}^{2+}$ & 0.80 & 17 & 36 & $3.2 \times 10^{2}$ & 56 & 0 \\
\hline $\mathrm{Pb}^{2+}$ & 1.21 & $3.0 \times 10^{3}$ & $1.8 \times 10^{2}$ & $15 \times 10^{2}$ & $2.0 \times 10^{3}$ & $2.3 \times 10^{2}$ \\
\hline $\mathrm{VO}^{2+}$ & - & $6.2 \times 10^{3}$ & $4.1 \times 10^{2}$ & $2.9 \times 10^{3}$ & 71 & 50 \\
\hline $\mathrm{Zn}^{2+}$ & 0.74 & 27 & 18 & $2.5 \times 10^{3}$ & $1.0 \times 10^{2}$ & 13 \\
\hline $\mathrm{Cd}^{2+}$ & 0.97 & $6.6 \times 10^{2}$ & 0 & $6.0 \times 10^{3}$ & 32 & 14 \\
\hline $\mathrm{Hg}^{2+}$ & 1.10 & $5.6 \times 10^{2}$ & 45 & $2.0 \times 10^{3}$ & 17 & 20 \\
\hline $\mathrm{Al}^{3+}$ & 0.50 & $2.6 \times 10^{2}$ & 29 & $2.2 \times 10^{3}$ & 29 & 0 \\
\hline $\mathrm{Ga}^{3+}$ & 0.62 & $1.8 \times 10^{3}$ & $4.3 \times 10^{2}$ & $2.0 \times 10^{3}$ & $5.2 \times 10^{2}$ & 2 \\
\hline $\mathrm{In}^{3+}$ & 0.81 & $1.1 \times 10^{3}$ & $5.2 \times 10^{2}$ & $2.4 \times 10^{3}$ & 59 & 9 \\
\hline $\mathrm{Y}^{3+}$ & 0.93 & 49 & 7 & $6.6 \times 10^{3}$ & 12 & 7 \\
\hline $\mathrm{La}^{3+}$ & 1.15 & 53 & 16 & $6.0 \times 10^{2}$ & 22 & $1.1 \times 10^{2}$ \\
\hline $\mathrm{Ce}^{3+}$ & 1.03 & 78 & 33 & $7.9 \times 10^{3}$ & 19 & 0 \\
\hline $\operatorname{Pr}^{3+}$ & 1.01 & 60 & 13 & $7.5 \times 10^{3}$ & 1 & 1 \\
\hline $\mathrm{Nd}^{3+}$ & 1.00 & 66 & $1.1 \times 10^{2}$ & $8.2 \times 10^{2}$ & 7 & 25 \\
\hline $\mathrm{Sm}^{3+}$ & 0.96 & 71 & 2 & $6.3 \times 10^{3}$ & 0 & 2 \\
\hline $\mathrm{Fe}^{3+}$ & 0.75 & $7.4 \times 10^{2}$ & $3.2 \times 10^{2}$ & $4.1 \times 10^{3}$ & 0 & 0 \\
\hline $\mathrm{Th}^{4+}$ & - & $1.9 \times 10^{3}$ & $5.7 \times 10^{2}$ & $4.9 \times 10^{3}$ & 100 & $4.0 \times 10^{2}$ \\
\hline $\mathrm{ZrO}^{2+}$ & - & $6.1 \times 10^{3}$ & $1.5 \times 10^{3}$ & $6.1 \times 10^{3}$ & $5.2 \times 10^{2}$ & $1.6 \times 10^{2}$ \\
\hline $\mathrm{HfO}^{2+}$ & - & $3.0 \times 10^{3}$ & $3.0 \times 10^{3}$ & $3.0 \times 10^{3}$ & $3.0 \times 10^{3}$ & $3.0 \times 10^{3}$ \\
\hline $\mathrm{Sc}^{2+}$ & 0.81 & $1.1 \times 10^{3}$ & $1.4 \times 10^{2}$ & $7.1+10^{2}$ & 25 & 44 \\
\hline
\end{tabular}

行なわれた226)227).

\section{9 リンアンチモン酸 $(\mathrm{SbP})$}

伊藤ら ${ }^{153) \sim 156)}$ にってはじめて SbP が合成され，ア ルカリ金属 $\mathrm{Sr}^{2+}, \mathrm{La}^{3+}$ に対して有用なイオン交換体で あることが見いだされた44(47)59)71). 塩化アンチモン(V) とリン酸溶液から合成され $\mathrm{Sb}_{2} \mathrm{O}_{5} / \mathrm{P}_{2} \mathrm{O}_{5}=2$ であり強酸 性のイオン交換体である.

交換容量は $1.5 \sim 2.0 \mathrm{meq} / \mathrm{g}$ でカラムに適したガラス 状物として得られる.セシウムとルビジウムの分離係数 は 4 以上で $\mathrm{ZrP}$ やイオン交換樹脂よりも大きい. 若干 溶解性が大きいがシリカゲルを担体として改善すること ができる76).

その他ピロリン酸スズ(II) は電子交換的性質があり, ヨウ素, $\mathrm{Fe}^{3+}$ や $\mathrm{Ag}^{+}$を還元する. その交換容量は $0.44 \sim 0.59 \mathrm{meq} / \mathrm{g}$ であった ${ }^{64)}$.

\section{3 ヘテロポリ酸锅類}

リン酸をモリブドリン酸アンモニウム（以下 AMP と し他のものも同様に表わす）として沈殿するときカリウ
ムが含まれていたり，硝酸カりウムで洗浄したりすると アンモニウムの一部が可逆的に置換されることはBaxter らによって指摘された ${ }^{55)}$. Meier ${ }^{213)}$ らの吸着等温線の 熱力学考察からこの反応は多分イオン交換反応によるも のと考えられた. Buchward ${ }^{74)}$ らによって Rb+ やC ${ }^{+}$ などについてのイオン交換性が指摘され，さらに 1958 年 $\mathrm{Smit}^{299)}$ によって AMP の $1.6 \mathrm{~mm}$ の小カラムでナ トリウムーカリウムールビジウムーセシウム相互の分離に 成功して以来, fission product の分離の可能性と構造の 興味などから数多くの研究がなされている.イオン交換 体としてのへテロポリ酸塩類の本および総説は古くは

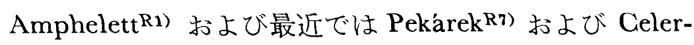
fieldR2) らによって行なわれている.

この種の化合物の組成は $\mathrm{H}_{m} \mathrm{XY}_{12} \mathrm{O}_{40} \cdot n \mathrm{H}_{2} \mathrm{O}(m=3$, $4,5)$ で表わされ, $\mathrm{H}$ とて, 銀, タリウム $(\mathrm{I}), \mathrm{NH}_{4}$, 8-quinorin, pyridinium, lutidinium や collidinum, $\mathrm{X}$ としてリ， ヒ素，ケイ素，ゲルマニウムやホウ素， およびYとしてモリブデン，タングステンやバナジウム が知られている.

・一般に熱安定性はルビジウム>セシウム>カリウム> 
ナトリウム>リチウムの MP の順である. $150^{\circ} \mathrm{C}$ で加 熱したものは MP や WSi では $150^{\circ} \mathrm{C}$ で無水物である が，WP では $2 \mathrm{H}_{2} \mathrm{O}$ を残す. $\left(\mathrm{NH}_{4}\right)_{3} \mathrm{PMo}_{12} \mathrm{O}_{40}$ で表わ される正塩は $0.1 M$ 硝酸中で $\mathrm{NH}_{4}: \mathrm{PMo}$ の添加比が $6: 1$ で得られ，一塩基酸 $\left(\mathrm{NH}_{4}\right)_{2} \mathrm{HMoP}$ は $3 M$ 硝酸中 で 1.7〜2.0:1 で得られる. 同様な調製法でルビジウ ムーセシウムー，カリウムーやタリウムーの正塩および一 塩基酸が得られた.

ヘテロポリ酸盐の特徴はアルカリ金属に対してすぐれ た分離能をもつことである。吸着性の順序はいずれも $\mathrm{Cs}^{+} \gg \mathrm{Rb}^{+}>\mathrm{K}^{+} \gg \mathrm{Na}^{+}>\mathrm{Li}^{+}$となり，ナトリウムーカ リウムやルビジウムーセシウムの相互分離にすぐれてい る302). 特に $\mathrm{Tl}_{2} \mathrm{HMP}$ がセシウムとルビジウムの分離 係数が最も高い196)。この TlMP によるセシウムの選択 的吸着は Hara'138) によって 1958 年に見いだされ，動 的方法による $\mathrm{Cs}^{+}$の便利な分離方法として提案されて いた.ほととど同時に Smit らによるAMP の系統的 イオン交換研究があったために影にかくれていたが， Krtil らによって $\alpha_{\mathrm{Rb}}^{\mathrm{Cs}}$ が最も大であることが確認され $た^{196)}$.

Table XII-1 Distribution coefficients of various cations in trace concentration with AMP in $0.1 M$ ammonium nitrate solution ${ }^{96}$

\begin{tabular}{cccc}
\hline Cation & $K_{d}$ & Cation (1) & \multicolumn{1}{c}{$K_{d}$} \\
\hline $\mathrm{Mg}$ & 0.81 & $\mathrm{Li}$ & 0.57 \\
$\mathrm{Ca}$ & 1.48 & $\mathrm{Na}$ & 0.73 \\
$\mathrm{Sr}$ & 1.34 & $\mathrm{~K}$ & $4 \cdot 7$ \\
$\mathrm{Ba}$ & 3.68 & $\mathrm{Rb}$ & 266 \\
$\mathrm{Mn}$ & 1.34 & $\mathrm{Cs}$ & 4024 \\
$\mathrm{Co}$ & 1.33 & $\mathrm{Ag}$ & 54 \\
$\mathrm{Ni}$ & 1.77 & $\mathrm{Tl}$ & 3939 \\
$\mathrm{Cu}$ & 1.92 & $\mathrm{H}{ }_{3} \mathrm{O}$ & 0.84 \\
$\mathrm{Zn}$ & 4.28 & & \\
$\mathrm{Cd}$ & 2.21 & & \\
\hline
\end{tabular}

3.1 モリブドリン酸アンモニゥム（ammonium 12molybdophosphate, AMP)

水または酸溶液中で安定なモリブドリン酸アンモニウ ムは $m$ が 3 に近い $\left(\mathrm{NH}_{4}\right)_{2.95}\left(\mathrm{H}_{3} \mathrm{O}\right)_{0.05}\left[\mathrm{PMo}_{12} \mathrm{O}_{24}\right] \cdot 11.6$ $\mathrm{H}_{2} \mathrm{O}^{197)}$ の組成をもち， $\mathrm{pH}$ によって若干異なった組成 を示す. 2 洒金属イオンからなる塩は複雑であり， $m=$ 2.68-3.10を示している.

ヘテロポリ酸の構造はよく知られているように $\left[\mathrm{PO}_{4}\right.$ $\left.\left(\mathrm{W}_{3} \mathrm{O}_{9}\right)_{4}\right]^{3-}$ が 2 個で体心立方格子を形成し，交換可能 な陽イオンは各りょうの中央に 3 個と各面心に 3 個で 計 6 個で電気的中性を保っている. 理論的交換容量は
$1.57 \mathrm{meq} / \mathrm{g}$ と計算されるが多くの場合立体効果のた め $1 \mathrm{meq} / \mathrm{g}$ 程度が有効な交換容量といえる. 最初の $\mathrm{NH}_{4}+$ が容易に交換されやすく，第 2 の $\mathrm{NH}_{4}{ }^{+}$は交換 しにくい.しかしながらこの交換は段階的ではない，小 さなアルカリ金属イオンは若干の水をともなっているが 大きなイオン，たとえば $\mathrm{Ba}^{2+}$ では次のように水分子な ぞを排除して交換する。

Table XII-2 separation factor values $\alpha_{\mathrm{Rb}}^{\mathrm{Cs}}$ for sorption(on thllous and ammonium salts of heteropolyacid when using ammonium salts at $0.01 \mathrm{M} \mathrm{HNO}_{3}{ }^{196}$ )

\begin{tabular}{ll}
\hline \hline Sorbent & $\alpha_{\mathrm{Rb}}^{\mathrm{Cs}}$ \\
\hline$\left(\mathrm{NH}_{4}\right)_{3} \mathrm{PMo}$ & 23.4 \\
$\left(\mathrm{NH}_{4}\right)_{3} \mathrm{PW}$ & 21.3 \\
$\left(\mathrm{NH}_{4}\right)_{2} \mathrm{HPMo}$ & 18.2 \\
$\left(\mathrm{NH}_{4}\right)_{2} \mathrm{HPW}$ & 14.5 \\
$\mathrm{Tl}_{2} \mathrm{HPMo}$ & 33.3 \\
$\mathrm{Tl}_{2} \mathrm{HPW}$ & 28.0 \\
\hline
\end{tabular}

$\left(\mathrm{NH}_{4}\right)_{3} \mathrm{MP}$ を 100\%としたときの各アルカリ金属の 最大の交換は $\mathrm{Li}^{+}, \mathrm{Na}^{+}, \mathrm{K}^{+}, \mathrm{Rb}^{+}, \mathrm{Cs}^{+}, \mathrm{Tl}^{+}$と $\mathrm{Ag}^{+}$ についてそれぞれ 20.9，26.4，48.7，53.6，45.3,45.8 および $64.8 \%$ を示し，ミク口量で $K_{d}$ 值の大きいセシ ウム, タリウム $(\mathrm{I})$ や銀が $\mathrm{R} \mathrm{b}^{+}$と比べて小さな值が得 られた ${ }^{95)}$. 2 価金属についても類似した関係が得られ， 特にアルカリ類金属では最大交換容量と $\mathrm{Be}^{2+}, \mathrm{Mg}^{2+}$, $\mathrm{Ca}^{2+}, \mathrm{Sr}^{2+}$ および $\mathrm{Ba}^{2+}$ などの結晶イオン径と直線関 係を示し， $\mathrm{Ba}^{2+}$ が $36.1 \%$ および $\mathrm{Be}^{2+} 27.8 \%$ の交換 率を示す ${ }^{96)} .2$ 価金属イオンの $K_{d}$ と $\log \mathrm{NH}_{4}{ }^{+}$の関 係は -1 の直線関係を示し,

$$
\begin{aligned}
2\left(\mathrm{NH}_{4}\right)_{2} \cdot\left(\mathrm{H}_{3} \mathrm{O}, \mathrm{NH}_{4}, \mathrm{Na} \text { etc }\right) \mathrm{MP}+\mathrm{M}^{2+} \\
\rightleftarrows\left[\left(\mathrm{NH}_{4}\right)_{2} \mathrm{MP}\right]_{2} \mathrm{Ba} \\
\quad+2\left(\mathrm{H}_{3} \mathrm{O}^{+}, \mathrm{NH}_{4}{ }^{+}, \mathrm{Na}^{+} \text {etc }\right)
\end{aligned}
$$

の反応によるものと考えられた ${ }^{303)}$. トレーサー量の1 価および 2 価金属の吸着順序は Table XII-1 に示し たように $\mathrm{Cs}^{+}=\mathrm{Tl}^{+}>\mathrm{Rb}^{+}>\mathrm{Ag}^{+}>\mathrm{Zn}^{+}=\mathrm{K}^{+}>\mathrm{Ba}^{2+}>$ $\mathrm{Cd}^{2+}>\mathrm{Cu}^{2+}>\mathrm{Ni}^{2+}>\mathrm{Cd}^{2+}>\mathrm{Mn}^{2+} \sim \mathrm{Sr}^{2+} \sim \mathrm{Co}^{2+} \sim$ $\mathrm{Co}^{2+}>\mathrm{H}_{3} \mathrm{O}+\sim \mathrm{Mg}^{2+}>\mathrm{Na}^{+}>\mathrm{Li}^{+}$安示す ${ }^{96}$.

$\mathrm{UO}_{2}{ }^{2+}$ は低い酸濃度でイオン種 $\mathrm{UO}_{2} \mathrm{OH}^{+}$として吸 着されるが123)，トリウム(IV) では主としてイオン交換 で部分的に非可逆的交換が起こる．これはトリウムーへ テロポリ錯体が形成したと考えている120)．タリウム(I) はセシウムと同程度に強く吸着され, 飽和硝酸アンモ二 ウムでも分離できないが，タリウム $(\mathrm{I}) を 0.05 \mathrm{M}$ 臭素 と $5 \%$ 臭化水素溶液で 酸化しながら溶離することがで 
き, $\mathrm{Ca}+$ は $12 M$ 硝酸アンモニウムで溶離することが できる289).

AMP のみならず他のヘテロポリ酸も同様であるが交 換体が微粒子であることと拡散速度が小さいのが欠点で それを改善するために，モリブドリン酸の水素形にアン モニウム塩溶液を接触させると $1 \mu$ 程度の微細結晶の集 合物が得られ，交換速度も大きく压損失も少ない交換体 を得ることができる300). また，シリカゲルに分散させ て交換体としての物理的条件を改善することができる.

雨水 ${ }^{168)}$, 原子炉の泠却水 ${ }^{228)}$ や海水 ${ }^{113)}{ }^{303)}$ からの ${ }^{137} \mathrm{Cs}$ 吸着などに応用できる. Table VII に示したように ${ }^{90} \mathrm{Y}$ ${ }^{90} \mathrm{Sr}$ や $\mathrm{Cd}^{2+-} \mathrm{In}^{2+}$ などに応用される168).

3.2 リンタングステン 酸塩（WP） AMP につい でよく研究されているへテロポリ酸で Krtil らによっ てよく研究されている188)189)197)。構造, 選択性などは AMP ときわめてよく類似しているがそれと比較して安 定性は若干よくないが交換容量は大となっている。ほか に種々のヘテロポリ酸が考えられるが $\mathrm{AWP}, \mathrm{Tl}_{3} \mathrm{WP} や$ $\mathrm{Tl}_{2} \mathrm{HWP}$ などが安定であり，純粋のナトリウムやカリ ウム塩は水に可溶である.

8-ヒドロキシキノリン-MP や-WP302) またはアルキ ルアンモニウム-MP73) が報告されたがいずれも AMP やAWP と比べて $\mathrm{NH}_{4}+$ に対するイオン交換能が小さ く, 溶解性も若干高くなる. それに対してピリジニウ ムイオンで置換したピリジニウムリンタングステン酸 (PWP) は組成や溶解度は AMP とほとえど同じで，水 を含まない状態の化合物である. $\mathrm{NH}_{4}^{+}>\mathrm{Cs}^{+} \gg \mathrm{Rb}^{+}>$ $\mathrm{K}^{+}>\mathrm{Na}^{+}$の吸着順序を示す. pyridinium, lutidinium, collidinium $の \mathrm{WP}$ も同様な方法によって調製される.

PiWP のアルカリ金属イオンの選択性は吸着等温線 から $\mathrm{NH}_{4}{ }^{+}>\mathrm{K}+>\mathrm{Na}^{+} \sim \mathrm{Li}^{+}$順となる. $\mathrm{NH}_{4}{ }^{+}$に対す る選択性は $\mathrm{PWP}>\mathrm{PiWP}>\mathrm{LWP}>\mathrm{CWP}$ の順であった。 ケイ酸タングステン酸塩 (WSi) は collidinium 塩 (CWSi)のタが不溶性で $\mathrm{NH}_{4}^{+}, \mathrm{K}^{+}, \mathrm{Na}^{+}, \mathrm{Li}^{+}, \mathrm{Sr}^{2+}$ および $\mathrm{Al}^{3+}$ の吸着は非常に小さい. しかしながらアル キルアンモニウムイオンのような大きなイオンを吸着す ることができ, その順序は $\left(\mathrm{CH}_{3}\right)_{4} \mathrm{~N}^{+}>\left(\mathrm{CH}_{3}\right)_{3} \mathrm{NH}^{+}>$ $\left(\mathrm{CH}_{3}\right)_{2} \mathrm{NH}_{2}{ }^{+}$でフォンデルワルス半径の増加とともに 増加する. AWS は水には可溶であるが沪紙に含浸して 乾燥したものは fission product やウランの分析に応用 できる210) (Table VII).

また，Mo-W ${ }^{198)} や \mathrm{Mo}-\mathrm{V}^{284)}$ との組み合わせも合成 され，その創合を变えることによってその特性が変わっ てくることがある. Mo: W が 1:2 よりも 2:1 のほ
うが $\mathrm{Cs}^{+}$の $K_{d}$ が若干大きい198).

4 不溶性フェロシアン化錯体

古くから無機化学や分析化学で陽イオンの沈殿剂とし てフェロシアン化物が用いられていた. またフェロシア ン化銅 (CuFC) は半透膜に応用されていた. 1958 年 Barton ら ${ }^{53)}$ によって放射性セシウムの選択的捕集剂と して報告され, Moore ら ${ }^{215) 216)} に よ っ て ~ \mathrm{Cs}^{+}$の吸着に すぐれた交換体であることが報告されて以来，銅，二ッ ケル, コバルト, 亜鉛などのフェロシアン化物が研究さ れている.

フェロシアン化物の可溶性塩に两鉛(II)，カドミウム や銅などの塩を加えると微結晶のフェロシアン化鍇体が 得られる.これらはいずれもセシウムに対して強い選択 性をもちルビジウムとセシウムの分蜼係数は AMPより もむしろ大きい, 銀, 覀鉛, カド之ウム, 銅, コバル ト, ニッケル, マンガン(II), 鉄(III), チタン(IV), ジルコニウム，バナジウム，モリブデン，タングステン およびウラン (IV) のフェロシアン化物が知られている. VFG，MoFG やWFC はむしろイソポリ酸に分類すべ きと思われる.

一般式は $\mathrm{M}^{2+}\left[\mathrm{N}^{2+}\left(\mathrm{Fe}(\mathrm{CN})_{6}\right]\right.$ が与えられ106), $\mathrm{N}^{2+}$ と $\mathrm{Fe}^{2+}$ は $\mathrm{CN}^{-}$と結合してともに挙動し, $\mathrm{M}^{2+}$ のみ が結晶格子の自由な空間に存在すると考えられる.ア ルカリ金属を含むフェロシアン錯体の組成は $\mathrm{A}_{2 x} \mathrm{M}_{1-x}$ $\left[\mathrm{NFe}(\mathrm{CN})_{6}\right]$ が提案され 106)245)， $x=0 \sim 1$ の間にある.

結晶構造は $\mathrm{Cu}_{2}\left[\mathrm{Fe}(\mathrm{CN})_{6}\right]$ について $\mathrm{a}=1.027 \mathrm{~nm}$,

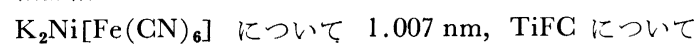
$\mathrm{a}=10.27 \mathrm{~nm}$ の面心立方格子をなし，ちょうど $\mathrm{Na}^{+}$の 代わりにニッケルが， $\mathrm{Cl}$ - の代わりに $\mathrm{Fe}(\mathrm{CN})_{6} \mathbf{4}^{4-}$ がは いり，単位胞の $1 / 8$ の大きさの中心に $\mathrm{K}+$ などの交換 可能なイオンがはいる. $\mathrm{K}_{2} \mathrm{Cu}\left[\mathrm{Fe}(\mathrm{CN})_{6}\right]$ では $\mathrm{a}=\mathrm{b}=$ $0.985 \mathrm{~nm}, \mathrm{c}=1.050 \mathrm{~nm}$ の面心立方格子を示す.

フェロシアン化物は酸に比較的安定で $0.01 〜 0.2 M$ 塭酸中で最も安定である45)208). 硝酸溶液中で鉄(II) は 鉄(III) に酸化されそのために $K_{d}$ の変化が起こる124). アルカリ性では若干加水分解する．硝酸溶液中ではコバ ルト 245), ニッケルと鉄(III) ${ }^{164)}$ のフェロシアン化物が 最も安定で，CuFC や CoFC は $\gamma$ 線に安定である.す でに述べたように重アルカリ金属をよく吸着する陽イオ ン交換体として挙動するが，CuFG はアニオン交換性も もっている164). アルカリ金属イオンについて最人の交 換容量を比較した絬果， $\mathrm{Fe}(\mathrm{III}) \mathrm{FG}<\mathrm{CuFC}<\mathrm{ZnFC}<$ $\mathrm{NiFC}<\mathrm{CoFC}$ の順に增加する ${ }^{106)}$. Table VI の交換谷 量はセシウムで表わしている。これらの做はおよそのめ 
やすであり，正確には調製条件，たとえば混合比，酸 性度，添加順序や，熟成条件などによって異なってく る. トレーサー量における $\log K_{d}$ と $\log \left[\mathrm{H}^{+}\right]$または $\log \left[\mathrm{NH}_{4}{ }^{+}\right]$は吸着イオンの価数に 相当する傾斜で 直線 関係をもつものが多いが，しばしば直線性からずれる場 合がある54192)193). TiFC では pH の増加とともにセシ ウムの $K_{d}$ 值が減少する. これは同時に陰イオンの吸着 が起こると説明されているが54)137)159)245)，そのほかに交 換体の溶解，フェロシアン化物中の鉄(II) の酸化や共 沈反応などがあり，特に多価イオンほど複雑な場合が多 w.

種々の FG 錯体について分離係数が測定され54)191)192) 194), $0.12 M$ 硝酸溶液からフェロシアン化ウランについ $\tau 1.8 \times 10^{3}$ の分離係数 $\alpha_{\mathrm{Rb}}^{\mathrm{Cs}}\left(\mathrm{NH}_{4}^{+}\right)^{194)}$ を得ているほ か, WFG で 26.0 ${ }^{190)}, \mathrm{VFC} て ゙ 100 \sim 110^{192)}$ の $\alpha_{\mathrm{Rb}}^{\mathrm{Cs}}$ 得ている.

$\mathrm{ZnFC}^{2} \mathrm{Na}^{+-} \mathrm{K}+$ や $\mathrm{Rb}^{+-} \mathrm{Cs}^{+}$の分離にすぐれ， fission product からのセシウムの分離に応用される182) 278). また，TLCによって $\mathrm{Na}^{+}-\mathrm{K}^{+}-\mathrm{Rb}^{+}-\mathrm{Cs}^{+}$を 13 $\min$ の短時間で分離に成功している ${ }^{162)}$ KCoFG で牛 乳，尿や海水からのセシウムの分離定量68)など数多くの 分析例がある (Table VII).

フェロシアン化錯体はその溶解性とカラムにする場合 に微細結晶であるため低い流速しか得られない欠点があ る.これを改善するためにアスベスト134)189)304)，汇紙79)， Charcal ${ }^{288)}$ ，シリカゲル51)315) やポリビニル酢酸などを 混ぜて吸着凨として便利な粒径に調製することができ る. Konecny̌ らは ZnFC, CuFC, GdFC, NiFC およ びFeFG についてセシウムの回収につごうのよいシリカ ゲル担体の調製法とその特性を比較した. トレース量セ シウムの吸着は硝酸濃度の増加とともに $\mathrm{ZnFC}, \mathrm{Fe}(\mathrm{III})$ FG や CuFC では減少するが, GdFC および NiFG で は $6 M$ 硝酸溶液でもほとんど変わらずほぼ $100 \%$ 吸着 する. $\mathrm{Fe}(\mathrm{CN})_{6} \mathbf{4}^{4}$ に対する $\mathrm{M}^{2+}$ は約 2 であり \{すな

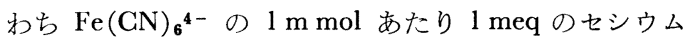
が吸着された\}，ほぼ理想的な交換が認められた（ZnFG を除いて $) \cdot \mathrm{Fe}(\mathrm{CN})_{6}{ }^{4-}$ の含有量とセシウム吸着量とは 直線関係にあり，したがって，シリカゲルは単に担体と してのタ挙動している.

5 種々の無機イオン交換体を忘用した 系統分析の例

高純度物質中の微量成分の分布は必ずしも均一ではな く多少偏析をして存在している場合が多い，また，環境 物試料では時間による変動があり，同一試料で系統的に
分析することが望まれる. Girardi ら 131)132) は 11 種の 酸溶液中で 11 種の交換体についてそのイオン交換挙動 をコンピューターカードに記憶させ（さらに 15 種類の 各種イオン交換体をつけ加えた), その中から最も単離 に適した系統的分析法の確立を検討している ${ }^{99)}$. これに よって高純度アルミニウムや亜鉛について, 系統的分析 を行なった例を Fig. 11-1 および Fig. 11-2 に示す. 放射化されたアルミニウム試料は硝酸一硫酸-リン酸混合 物でエッチングしたのち，七素とアンチモンを高酸化状 態にしておくために数滴の硝酸を加えたのち $6 M$ 塩酸で 還流して溶解する. はじめ Dowex 1 を用いて二つの群 に分けたのち, Fig. 11-1 に示したように各種の無機イ オン交換体を用いて単離している. カリウムーネプッニ ウムや金-アンチモンータングステンは容易に $\gamma$ 線スペク トロメーターで同時に測定できる. Fig. 11-2 は電解亜 鉛から带溶融法までの系統分析を行なった系統図であり 21 元素について ppb オーダーのものも検出できる. ま

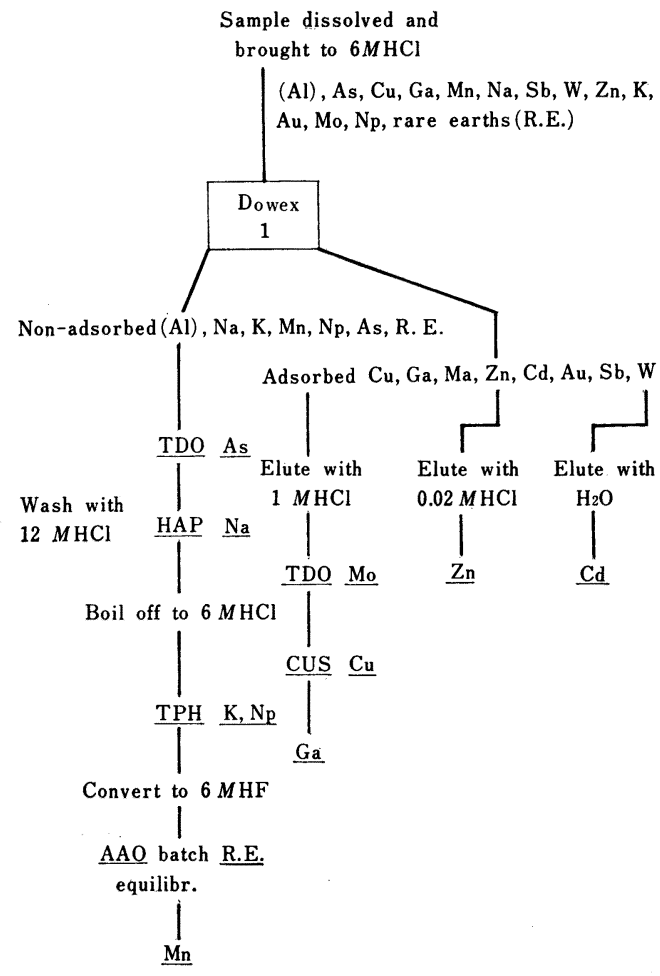

Fig. 11-1 Scheme for the systematic separation of impurities giving rise to radionuclides with half-lives shorter than a few days, in neutron-activated high-purity aluminum ${ }^{99)}$ 


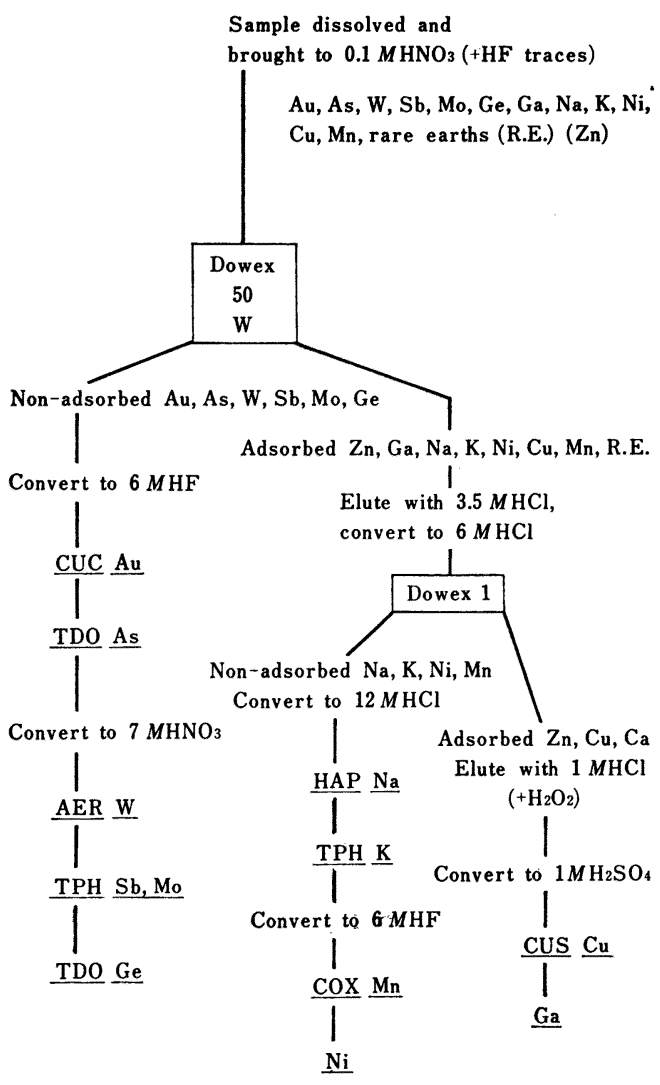

Fig. 11-2 Scheme for the systematic separation of impurities giving rise to radionuclides with half-lives shorter than a few days, in neutron-activated high-purity zinc ${ }^{99)}$

た, 金属亜鉛の NBS 標準試料について比較検討した結 果, マンガン，アンチモン，コバルトなどについて良好 な結果が得られた。 また，16 元素について検出限界を 示すことができた.

\section{6 あとがき}

前稿および本稿において無機イオン交換体の分析化学 への応用についてできるだけ集録することに努力をした が，その応用範囲は多方面にわたりから吸着特性も複雑 であるのでじゅうぶん意を尽くすことができず，集録に もれた重要な論文も多数あるように思われる. 本稿を草 するにあたって AmphlettR1) や MarinskyR2) らの成書 および Fuller, VeselyR6), PekârekR7) および Qureshi らR8）の総説がよい参考になった。

無機イオン交換体に対する関心はここ数年の間に急速 に高まっているように思われる. 米国では Clearfied お
よび Mancollas を中心にその物性や熱力学的研究が盛 んであり, 分析化学的応用は東欧および西欧諸国とソ連 で盛んに行なわれている.

無機イオン交換体の吸着特性はくりかえし述べたよう に調製条件によって変わり，単一化合物か混合物かの問 題やイオン交換以外の物理吸着, 表面吸着, 沈殿生成や 共沈現象などを伴う場合もあり複雑である. それにもか かわらず，よい再現性を得るための研究や吸着現象をよ く説明するための基礎的研究が続けられ，さらに新しい 交換体を得るための合成とそれらのイオン交換性が検討 されている. 無機イオン交換体が耐熱性や耐放射線性を もつのみならず，すぐれた選択性が期待されるために今 後ますます発展するものと思われる。

特に多量成分の中から特定の微量成分を分離する必要 性は ppb オーダーの定量や分離が問題となる放射性物 質や環境試料においてますます重要となることが考えら れる. すでに結晶性アンチモン酸に対する $\mathrm{Na}^{+}, \mathrm{Al}_{2} \mathrm{O}_{3}$ や $\mathrm{H}-\mathrm{SnO}_{2}$ への $\mathrm{PO}_{4}{ }^{3-}$ $\mathrm{AsO}_{4}{ }^{3-}, \mathrm{MnO}_{2}$ への $\mathrm{K}^{+}$ や $\mathrm{Mn}^{2+}, \mathrm{AMP}$ $\mathrm{ZnFC}, \mathrm{ZrP}, \mathrm{ZrAs} \wedge の \mathrm{Cs}^{+}$, ZrPSi への $\mathrm{Pu}$, TiAs への $\mathrm{Pb}^{2+}$, TiW への $\mathrm{Pb}^{2+} ゃ$ $\mathrm{Hg}(\mathrm{II}), \mathrm{TiSe} の \mathrm{Cd}^{2+}, \mathrm{SnP} へ の \mathrm{Au}^{3+}$ と $\mathrm{Sb}^{3+}$, $\mathrm{Sb}^{5+}, \mathrm{Pd}^{2+}, \mathrm{Pt}^{4+}, \mathrm{As}^{5+}$, アルカリ金属, $\mathrm{SnW} へ$ ○ $\mathrm{Mg}^{2+}$ ，アルカリ金属, $\mathrm{Au}^{3+}, \mathrm{Ag}^{+}$や $\mathrm{Pt}^{4+}, \mathrm{SnSe} へ の$ 4 価金属, 希土類, $\mathrm{Pb}^{2+}, \mathrm{Cu}^{2+}$ や $\mathrm{UO}_{2}^{2+}, \mathrm{CeW}$ への $\mathrm{Hg}^{2+}, \mathrm{Cr}-\mathrm{TripP}$ ヘのアルカリ金属や $\mathrm{Ag}^{+}$, ヘテロポ リ酸やフェロシアン化物への $\mathrm{Cs}^{+}$や $\mathrm{Sr}^{2+}$ の選扒的吸 着などはすぐれた分離剤 (inorganic separator または selective radio-ion filter) ${ }^{133)}$ としての高い有朋性を示 している.

これらの多彩な無機イオン交換体の特異的選护特性を コンピューターに記憶させ，その中から最も効果的です ぐれた分離条件を選択する試みが Girardi らによっては じめられている. したがって再現性よく調製された交換 体が必要となり，その合成法やイオン交換性の基礎的研 究はますます重要となると考光られる.

わが国でも最近河村R9) による放射化学分析への忍朋 や日下R11) の放射化分析への念朋の解説などがあり, 無 機イオン交換体に対する関心が高まりつつあるように思 われる.

本稿を草するにあたり交献の收集と整理にご協力をい ただいた本学理学部助手:吉田哲郎氏に感谢する。

\section{交献}

\section{成毒および総説}

R1) C. B. Amphlett : "Inorganic Ion Exchangers", (1964), (Elsevier, Amsterdam). 
R 2) A. Clearfield, G. H. Nancollas, R. H. Blessing (J. A. Marinsky, Y. Marcus, Eds.) : "Ion Exchange and Solvent Extraction", Vol 5, Chap. 1, (1973), (Marcel Dekker Inc., New York).

R3) 重松恒信: 化学, 21, 111, 214 (1966).

R4) 伊藤卓爾, 阿部光雄: 高分子化学, 18, No. 206, 300 (1969).

R5）館盛勝一, 天野 恕：日本原子力研究所報告, JAERI memo, 3726 (1969).

R6) V. Vesely, V. Pekarek : Talanta, 19, 219 (1972).

R 7) V. Pekarek, V. Vesely : ibid., 19, 1245 (1972).

R8) M. Qureshi, S. Z. Qureshi, J. P. Gupta, H. S. Rathore : Separ. Sci., 7, 615 (1972).

R9) 河村正一：化学教育, 21, 236 (1972).

R 10) 阿部光雄 : 同上, 22, 16 (1973).

R11) Y. Kusaka : Radioisotopes(Tokyo), 21, 238(1972).

R12) M. Lederer, C. Majani : Chromatogr. Rev., 12, 239 (1972).

R13) W.P.Thistlethwaite : Chem.Soc. (London), Spec. Publ. No. 22, 1967, 416.

R 14) 阿部光雄 : 本誌, 23, 1254 (1974).

論 交

1) 阿部光雄, 伊藤卓爾: 工化, 70, 440 (1967).

2) M. Abe, T. Ito : Bull. Chem. Soc. Japan, 41, 2366 (1968).

3) 阿部光雄, 伊藤卓网, 飯島 基 : 日本化学会第21 年会講演予稿集, II, p. 962 (1968).

4) 阿部光雄, 見城忠男, 伊藤卓爾 : 工化, 70, 291 (1967).

5) S.Ahrland : Fr.Patent 1, 473, 361 (1967) : Chem. Abstr., 67, 11737 (1967).

6) S. Ahrland, J. Albertsson : Acta Chem. Scand., 18, 1861 (1964).

7) S. Ahrland, J. Albertsson : ibid., 23, 1446(1969).

8) S. Ahrland, J. Albertsson, A. Alnas, S. Hemmingsson, L. Kullberg : ibid., 21, 195 (1967).

9) S. Ahrland, J. Albertsson, L. Johansson, B. Nihlgard, L. Nilsson : ibid., 18, 707 (1964).

10) S. Ahrland, J. Albertsson, L. Johansson, B. Nihlgard, L. Nilsson : ibid., 18, 1357 (1964).

11) S.Ahrland, J. Albertsson, \&. Osharsson : J.Inorg. Nucl. Chem., 32, 2069 (1970).

12) S. Ahrland, G. Carleson : ibid., 33, 2229 (1971).

13) T. Akiyama, I. Tomita : ibid., 35, 2971 (1973).

14) G. Alberti : ibid., 28, 658 (1966).

15) G. Alberti, S. Allulli, A. Conte : J. Chromatogr., 24, 148 (1966).

16) G. Alberti, P. Cardini-Galli, U. Costantino, E. Torracca : J. Inorg. Nucl. Chem., 29, 571 (1967).

17) G. Alberti, A. Conte, E. Torracca : ibid., 28, 225 (1966).

18) G. Alberti, U. Costantino : J. Chromatogr., 50, 482 (1970).

19) G. Alberti, U.Costantino : J. Inorg. Nucl.Chem., 35, 1347 (1973).

20) G. Alberti, U. Costantino, S.Allulli, M.A. Massucci : ibid., 35, 1339 (1973).

21) G. Alberti, U. Costantino, S. Allulli, M. A. Massucci, N. Tomassini : ibid., 36, 653 (1974).

22) G. Alberti, U. Costantino, S. Allulli, M.A. Massucci, N. Tomassini : ibid., 36, 661 (1974).

23) G. Alberti, U. Costantino, F. Di Gregorio, E. Torracca : ibid., 31, 3195 (1969).
24) G. Alberti, U. Costantino, P. G. Gregorio, E. Torracca : ibid., 30, 295 (1968).

25) G. Alberti, U. Costantino, M. Pelliccioni : ibid., 35, 1327 (1973).

26) G.Alberti, U.Costantino, L.Zsinka : ibid., 34, 3549 (1972).

27) G. Alberti, G. Giamnari, G. Grassini-Strazza : J. Chromatogr., 28, 118 (1967).

28) G. Alberti, G. Grassini : ibid., 4, 83 (1960).

29) G. Alberti, G. Grassini : ibid., 4, 423 (1960).

30) G.Alberti, M.A.Massucci : J.Inorg. Nucl.Chem., 32, 1719 (1970).

31) G. Alberti, M. A. Massucci, E. Torracca : $J$. Chromatogr., 30, 579 (1967).

32) G. Alberti, E. Torracca : J. Inorg. Nucl. Chem., 30, 317 (1968).

33) G. Alberti, E. Torracca : ibid., 30, 3075 (1968).

34) G. Alberti, E. Torracca, A. Conte : ibid., 28, 607 (1966).

35) J. Albertsson : Acta Chem. Scand., 20, 1689 (1966).

36) S. Allulli, G. Cardini : J. Inorg. Nucl. Chem., 34, 339 (1972).

37) H. F. Aly, S. Marei, N. Zakareia : Mikrochim. Acta, 1973, 1.

38) C. B. Amphlett : Proc. 2nd Intern.Conf. Peaceful Uses Atom. Energ., Geneva, No. 15, p. 171 (1958).

39) C. B.Amphlett, P.J. Jones : J.Inorg. Nucl.Chem., 26, 1759 (1964).

40) C. B. Amphlett, L. A. McDonald : Proc. Chem. Soc., 1962, 276.

41) C. B. Amphlett, L. A. McDonald, J. S. Burgess, J. C. Maynard : J. Inorg. Nucl. Chem., 10, 69 (1959).

42) C. B. Amphlett, L. A. McDonald, M. J. Redman : ibid., 6, 220 (1958).

43) S. Araki, S. Suzuki, M. Yamada : Talanta, 19, 577 (1972).

44) L. H. Baetslé, D. Huys : Belg. Patent 649, 746 (1964) ; Chem. Abstr., 63, 14103 (1965).

45) L. H. Baetslé, D. van Deyck, D. Huys : ibid., 27, 683 (1965).

46) L.H.Baetslé, D.van Deyck, D.Huys, A.Guery : AEC Accession No. 7613, Rept. No. BLG-267 (1964) ; Chem. Abstr., 62, 15714 (1972).

47) L.H.Baetslé, D.van Deyck, D.Huys, A.Guery : Report EUR 2497e (1965).

48) L. H. Baetslé, J. Pelsmakers : J. Inorg. Nncl. Chem., 21, 124 (1961).

49) A. A. Balandin, A. I. Kukina, V. I. Lygin, N. E. Malenberg : Teor. Eksp. Khim., 3, 561 (1967).

50) G. Balon, C. Beaudet, J. Piret, W. R. Ruston : Kerntech., Isotopentech. Chem. Z. Ing. Aller. Fachrichtungen, 9, 258 (1967) ; Chem. Abstr., 70, 83295 (1969).

51) V. I. Barnovskii, Ya. Viza, G. S. Katykhin, M. K. Nikitin : Radiokhimiya, 9, 698 (1967).

52) K. V. Barsukova, G. N. Rodinova : ibid., 10, 86 (1968) ; Chem. Abstr., 68, 110561 (1968).

53) G.B.Barton, J.L.Hepworth, E.D.McClanahan, R. L. Moore, H. H. van Tuyl : Ind. Eng. Chem., 50, 212 (1958).

54) J. Bastian, K. H. Lieser : J. Inorg. Nucl. Chem., 
29, 827 (1967).

55) G. P. Baxter, R. C. Griffin : Amer. Chem. J., 34, 204 (1905).

56) M. L. Beasley, W. O. Milligan : Trans. N. Y. Acad. Sci., 31, 261 (1969).

57) C.Beaudet, J.Cremer, G. Demaere : Atompraxis, 15, 165 (1969).

58) Belg. Patent 649, 389 (1964)

59) F.A. Belinskaya, E. A. Materova, O.P. Shuřalova, L. A. Karmanova, O. I. Bulyaeva : "Ionyi Obmen", p. 43, Izdatelstvo, Leningrad, Universiteta, 1965.

60) H. Bernhard, K. H. Lieser : Radiochim. Acta, 11, 153 (1969) ; Chem. Abstr., 71, 76457 (1969).

61) D. Betteridge, G. N. Stradling : J. Inorg. Nucl. Chem., 29, 2652 (1967).

62) D. Betteridge G. N. Stradling : ibid., 31, 1507 (1969).

63) J. A. Bittles : U. S. Patent 3, 499, 537 (1970) ; Chem. Abstr., 72, 115168 (1970).

64) E. S. Boichinova, E. V. Kharitonova : Zh. Prikl. Khim. (Leningrad), 38, 674 (1965).

65) E. S. Boichinova, T. I. Podgorelova : ibid., 40, 1833 (1967).

66) E. S. Boichinova, D.A.Sokolova : ibid., 38, 1732 (1965).

67) E. S. Boichinova; G. N. Strel'nikova : ibid., 40, 1443 (1967); Chem. Abstr., 68, 6675 (1968).

68) A. L. Boni : Anal. Chem., 38, 89 (1966).

69) A. Bounin, P. Poirier : Fr. Patent 1, 480, 148 (1967) ; Chem. Abstr., 67, 121766 (1967).

70) G.Branca : Acqua Ind., 7, 19(964) ; Chem.Abstr., 64, 17245 (1966).

71) R.F. Brigevich, R.A.Kuznetsov : Radiokhimiya, 9, 693 (1967).

72) R. F. Brigevich, R.A. Kuznetsov : Vestn. Leningrad Univ., Fiz., Khim., 145 (1969) ; Chem.Abstr., 71, 105645 (1969).

73) R. W. C. Broadbank, S. Dhabanandana, R. D. Harding : J. Inorg. Nucl. Chem., 23, $311(1961)$.

74) I. Buchwald, W. P. Thistlethwaite : ibid., 5, 341 (1958).

75) R. Caletka, G. Konečny : Rep.Cesk.Akad.Ved. UJV, 3643ch, p. 31 (1971) ; Anal. Abstr., 23, 1270 (1972).

76) R. Caletka, G. Konečny : Radiochem. Radioanal. Letters, 9, 285 (1972).

77) R. Caletka, G. Konečny : ibid., 12, 325 (1972).

78) J. A. Carlson, K. A. Kraus, J. S. Johnson, Jr., H. O. Phillips : ORNL-1853, p. 203 (1955).

79) H. L. Caron, T. T. Sugihara : Anal. Chem., 34, 1082 (1962).

80) Chu-Chun Chang, Pe-Hai Yin, Chen-Pang T'ung, Shih-Nien Shen : Hua Hsueh Pao, 31, 218 (1965) ; Chem. Abstr., 63, 15526 (1965).

81) A. Clearfield : Zirconium Phosphate, Research Report, Titanium Alloy Div., National Lead Co., Niagara Falls, N. Y., 1964.

82) A. Clearfield, R. H. Blessing : J. Inorg. Nucl. Chem, 34, 2643 (1972).

83) A. Glearfield, R. H. Blessing : ibid., 36, 1174 (1974).

84) A. Clearfield, R. H. Blessing, I.A.Stynes : ibid.,
30, 2249 (1968).

85) A. Clearfield, W. L. Duax : Acta Cryst., B25, 2658 (1969).

86) A. Clearfield, W. L. Duax, A. S. Medina, G. D. Smith, J. R. Thomas : J. Phys. Chem., 73, 3424 (1969)

87) A. Clearfield, A. S. Medina : J. Inorg. Nucl. Chem., 35, 2985 (1973).

88) A.Clearfield, G.D. Smith : ibid., 30, 327 (1968).

89) A. Clearfield, G. D. Smith : J. Colloid Interf. Sci., 28, 325 (1968).

90) A. Clearfield, G. D. Smith : Inorg. Chem., 8, 431 (1969).

91) A. Clearfield, G. D. Smith, B. Hammond : $J$. Inorg. Nucl. Chem., 30, 277 (1968).

92) A. Clearfield, J. A. Stynes : ibid., 26, 117 (1964).

93) C. J. Coetzee : J. Chem. Educ., 49, 33 (1972).

94) C. J. Coetzee, E. F. C. H. Rohwer : Anal. Chim. Acta, 44, 293 (1969).

95) G. J. Coetzee, E. F. C. H. Rohwer : J. Inorg. Nucl. Chem., 32, 1711 (1970).

96) C. J. Coetzee, A. J. van Wyk : ibid., 33, 1501 (1971).

97) U. Costantino, A. Gasperoni : J. Chromatogr., 51, 289 (1970).

98) M. Csajka : Radiochem. Radioanal. Letters, 13, 151 (1973)

99) J. Cuypers, F. Girardi, F.Mousty : J. Radioanal. Chem., 17, 115 (1973).

100) D. Gvjeticanin, N. Milic : Bull. Boris Kidrich Inst. Nucl. Sci., 15, 73 (1964) ; Chem. Abstr., 62, 15702 (1965)

101) C. Czibody, L. Szirtes, L. Zsinka : Radiochem. Radioanal. Letters, 8, 11 (1971).

102) C. Czibody, L. Zsinka, L. Szirtes : Magy. Kem. Lapja, 24, 470 (1969) ; Chem. Abstr., 72, 93649 (1970).

103) B. M. Davis, F. Sebba : J. Appl. Chem. (London), 17, 40 (1967).

104) P. DeBruyne : J. Inorg. Nucl. Chem., 32, 346 (1970).

105) N. E. Denisova, E. S. Boichinova, A. A. Peregodova : Zh. Prikl. Khim. (Leningrad), 39, 1235 (1966).

106) J. Doležal, V. Kouř́m : Radiochem. Radioanal. Letters, 1, 295 (1969).

107) R. Dolique, F. Ouenoun : Trav. Soc. Pharm. Montpellier, 26, 353 (1966).

108) J. D. Donaldson, M. J. Fuller : J. Inorg. Nuel. Chem., 33, 4311 (1971).

109) A. Dyer, D. Leigh, F. T. Ocon : ibid., 33, 3141 (1971).

110) G. Eisenman : Biophy. J., 2, 259 (1962).

111) M. Fedoroff, L. Debove : C. R. Acad. Sci., C275, 1189 (1972)

112) J. R. Feuga, T. Kikindai : Compt. Rend. Acad. Sci. (Paris), C264, 8 (1967).

113) A. J. R. da Fonseca, M.H.D. da Matos, M. M. da Cruz Godinho : Rev. Port. Quim., 6, 17 (1964).

114) J. O. Francis, G. Oldham : Loughborough Univ. Technol., Dept. Chem., Sum. Final Year Stud.Proj. Theses, 10, 23 (1969) ; Chem. Abstr., 73, 51967 
(1970).

115) Ch. Friedmann, T. S hönfeld : Radiochem. Radioanal. Letters, 2, 333 (1969).

116) M. J. Fuller : J. Inorg. Nucl. Chem., 33, 559 (1971).

117) E. Füssy, L. Szirtes : Radiochem. Radioanal. Letters, 8, 19 (1971).

118) I. Gal, N. Peric : Mikrochim. Ichnoanal. Acta, 251 (1965) ; Chem. Abstr., 63, 7 (1965).

119) I. Gal, A. Ruvarac : J. Chromatogr., 13, 549(1964).

120) M. T. Ganzerli-Valentini, V. Maxia, M. Barbaro-Forleo : Radiochem. Radioanal. Letters, 2, 225 (1969).

121) M. T. Ganzerli-Valentini, V.Maxia, S.Meloni, A. Martinelli : ibid., 11, 179 (1972).

122) M. T. Ganzerli-Valentini, V. Maxia, S. Meloni, A. Martinelli, M.A.Rollier : J.Radioanal.Chem., 11, 179 (1972).

123) M. T. Ganzerli-Valentini, V.Maxia, M.A.Rollier, M. Barbaro-Forleo : J. Inorg. Nucl. Chem., 32, 671 (1970).

124) M. T. Ganzerli-Valentini, S.Meloni, V. Maxia: ibid., 34, 1427 (1972).

125) P. J. Gellings : J. Phys. Chem., 54, 296 (1967).

126) J.S.Gill, S.N.Tandon : Talanta, 19, 1355(1972).

127) J. S. Gill, S. N. Tandon : J. Inorg. Nucl. Chem., 34, 3885 (1972).

128) J.S.Gill, S.N.Tandon : J. Radioanal. Chem., 13, 391 (1973)

129) J. S. Gill, S. N. Tandon : Radiochem. Radioanal. Letters, 14, 379 (1973).

130) J. S. Gill, S. N. Tandon : J. Radioanal. Chem., 20, 5 (1974).

131) F. Girardi, G. Guzzi, G. DiCola : ibid., 6, 359 (1970).

132) F. Girardi, R. Pietra, E. Sabbioni : ibid., 5, 141 (1970).

133) F. Girardi, E. Sabbioni : ibid., 1, 169 (1968).

134) B. Gorenc, L. Kosta : Z. Anal. Chem., 223, 410 (1966).

135) H.P.Gregor: J. Am.Chem.Soc., 70, 1293 (1948); 73, $642(1950)$.

136) S. D. Grekov, V.A.Leitsin : Zh. Neorgan. Khim., 13, 1133 (1968).

137) R. B. Hahn, H. G. Klein : Anal. Chem., 40, 1135 (1968).

138) T. Hara : Bull. Chem. Soc. Japan, 31, 635 (1958).

139) T. V. Healy : Radiochim. Acta, 3, 100 (1964).

140) T. V. Healy : ibid., 3, 106 (1964).

141) M. D. Hont, L. H. Baetslé : Mededel. Koninkl. Vlaam. Acad. Westenschap., Berg., Kl. Wetenschap, 27, 31 (1965).

142) E. P. Horwitz : J. Inorg. Nucl. Chem., 28, 1469 (1966).

143) S. W. Husain : Analusis, 1, 314 (1972).

144) S. W. Husain, M. Gulabi : Separ. Sci., 6, 737 (1971).

145) S. W. Husain, S. K. Kazmi : Experientia, 28, 988 (1972) ; Chem. Abstr., 74, 1429 (1973).

146) D. Huys, L. H. Baetslé : J. Inorg. Nucl. Chem., 27, 2459 (1965).

147) D.Huys, L.H. Baetslé : Centre Energ. Nucl. (Brussel) BLG-422, p. 8 (1967) ; Chem. Abstr., 68,
45033 (1968).

148) Y.Inoue : Bull.Chem.Soc.Japan, 36, 1316 (1963).

149) Y. Inoue : ibid., 36, 1325 (1963).

150) Y. Inoue : J. Inorg. Nucl. Chem., 26, 2241 (1964).

151) Y.Inoue, S. Suzuki, H. Goto : Bull.Chem. Soc. Japan, 37, 1547 (1964).

152) B. Z. Iofa, L. Zsinka, L. Szirtes : Radiokhimiya, 10, 491 (1968).

153) T. Ito, M. Abe : Bull. Chem. Soc. Japan, 34, 1736 (1961).

154）伊藤卓爾，阿部光雄 : 電化，33，175 (1965).

155) 伊藤卓爾, 阿部光雄: 特許公告, 410,102 .

156) 伊藤卓爾, 阿部光雄 : 同上, 617, 420 (1971).

157) 伊藤卓爾, 阿部光雄 : 同上, 696, 009 (1972).

158) A. V. Jadhav, Ch. L. Rao, G. J. Shahani : Proc. Nucl. Radiat. Chem. Symp., 3rd (Bombay, India), p. 436 (1967).

159) S. Kawamura, H. Kuraku, K. Kurotaki : Anal. Chim. Acta, 49, 317 (1970).

160) S. Kawamura, K. Kurosaki : J. Chromatogr., 45, 331 (1969).

161) S. Kawamura, K. Kurotaki, M. Izawa : Bull. Chem. Soc. Japan, 42, 3003 (1969).

162) S. Kawamura, K. Kurotaki, H. Kuraku, M. Izawa : J. Chromatogr., 26, 557 (1967).

163) S. Kawamura, S. Shibata, K. Kurotaki : Anal. Chim. Acta, 56, 405 (1971).

164) E. V. Kazakov, I. F. Karpova : Vestn. Leningrad Univ., Ser. Fiz. Khim., 20, 95 (1965).

165) E. V. Kazakov, I. F. Karpova : ibid., 21, 139 (1966).

166) E. V. Kazakov, I. F. Karpova : ibid , 21, 141 (1966).

167) K. Kimura : Japan At. Energ. Res. Inst., Rept., JAERI-1178, p. 23 (1966).

168) I. S. Kirin, Yu. K. Gusev, A. N. Mosevich, N. P. Kuznecov, V. S. Gusel'nikov : Radiokhimiya, 7, 736 (1965) ; Chem. Abstr., 64, 15364 (1966).

169) 小林悦郎, 後藤藤太郎 : 工化, 73, 692 (1970).

170) C. Konečny̌, R.Caletka : J.Radioanal.Chem., 14, 255 (1973).

171) K. H. König, K. Demel : J. Chromatogr., 39, 101 (1969).

172) K.H. König, G.Eckstein : J. Inorg. Nucl. Chem., 31, 1179 (1969).

173) K.H.König, G.Eckstein : ibid., 34, 3771 (1972).

174) K.H.König, G.Eckstein : ibid., 35, 1359 (1973).

175) K. H. König, H. Graf : J. Chromatogr., 67, 200 (1972).

176) K. H. König, F. Hyer : Atompraxis, 11, 275 (1965).

177) K. H. König, E. Meyn : J. Inorg. Nucl. Chem., 29, 1153 (1967).

178) K. H. König, E. Meyn : ibid., 29, 1519 (1967).

179) K.H.König, E.Meyn : G.Eckstein : Anal.Chim. Acta, 42, 540 (1968).

180) K. H. König, H. Schäfer, F. Hoyer, G. Rassl: Radiochim. Acta, 1, 213 (1963).

181) E. A. Koshcheeva, V. V. Volkhin : Zh. Neorgan. Khim., 12, 2760 (1967).

182) V. Kouřim, B. Million : Collection Czech. Chem. Commun., 30, 2848 (1965).

183) V. Kouřim, J. Rais, B. Millon : J. Inorg. Nucl. 
Chem., 26, 1111 (1964)

184) V. Kouřim, J. Rais, J. Stejskal : ibid., 26, 1761 (1964).

185) A.S. Kozlov, Yu.Mizhidiin : Red.Shchelochnye Elem., Sb. Dokl. Vses. Soveshch., 2nd, Novosibirsk, p. 300 (1964).

186) K. A. Kraus, T. A. Carlson, J. S. Johnson, D. J. Coombe, H. O. Phillips : ORNL-2004, p. 208 (1956).

187) K. A. Kraus, H. O. Phillips, T. A. Carlson, J. S. Johnson : Proc. 2nd Intern. Conf. Peaceful Uses Atom. Energ., Geneva, No. 15, p. 1832 (1958).

188) J. Krtil : J. Inorg. Nucl. Chem., 19, 298 (1961).

189) J. Krtil : ibid., 22, 247 (1961).

190) J. Krtil : ibid., 27, 233 (1965).

191) J. Krtil : ibid., 27, 1862 (1965).

192) J. Krtil : J. Chromatogr., 21, 384 (1965).

193) J. Krtil : ibid., 21, 85 (1966).

194) J. Krtil : Radiochim. Acta, 7, 30 (1967).

195) J. Krtil : J. Radioanal. Chem., 1, 201 (1968).

196) J. Krtil, M. Chavko : J. Cromatogr., 27, 460 (1967).

197) J. Krtil, V. Kouřim : J. Inorg. Nucl. Chem., 12, 367 (1959).

198) J. Krtil, I. Křivý : ibid., 25, 1191 (1963).

199) D. I. Kurbatov, S. A. Pavlova : Tr. Inst.Khim., Akad. Nauk SSSR, Ural. Filial, No. 10, 73 (1966).

200) V. G. Kuznetsov, Z. V. Popova, G. B. Seifer : Zh. Neorgan. Khim., 15, 2710 (1970).

201) K. V. Lad, D. R. Bax : Indian J. Technol., 10, 224 (1972).

202) J. L. Lambert, D. J. Manzo : Anal. Chim. Acta, 54, 530 (1971).

203) A.M.Landis : M.S.Thesis, Ohio Univ., Athens, Ohio, June, p. 18, 1970.

204) E. M. Larsen, W. A. Cilley : J. Inorg. Nucl. Chem., 30, 287 (1968).

205) E. M. Larsen, D. R. Vissers : J. Phys.Chem., 64, 1732 (1960).

206) J. Lefebvre, J. Prospert, A. Raggenbass : Fr. Patent 1, 393, 546 (1965) ; Chem. Abstr., 63, 14102 (1965).

207) M. Lesigang-Buchtela, K. Buchtela : Mikrochim. Acta, 1967, 1164 ; Chem. Abstr., 686709 (1968).

208) K. A. Lieser, J. Bastian, A. B. H. Hecker, W. Hild : J. Inorg. Nucl. Chem., 29, 815 (1967).

209) W. J. Maeck, M. E. Kussy, J. E. Rein : Anal. Chem., 35, 2086 (1963).

210) G. Marcu, L. Ghizdavu : Stud. Univ. Babes-Bolyani, Ser. Chem., 14, 39 (1969) ; Chem. Abstr., 72, 8851 (1970).

211) G. S. Martinchik, G. L. Starohinets : Issled. Svoistv. Ionoobmen. Materialov, Akad. Nauk SSSR, Inst. Fiz. Khim., p. 152 (1964).

212) L. O. Medeiros : J. Inorg. Nucl. Chem., 28, 599 (1966).

213) H. Mejer, W. D. Treadwell : Helv. Chim. Acta, 34, 155 (1951).

214) E. Michel, A. Weiss : Z. Naturforsch, B22, 1100 (1967).

215) F. L. Moore : Anal. Chem., 43, 487 (1971).
216) R. L. Moore, R. E. Burns : Proc. 2nd Intern. Conf. Peaceful Uses Atom. Energ., Geneva, No. 18, p. 231 (1958).

217) B. F. Myasoedov, K. V. Barsakova, G. N. Rodionova : Radiochem. Radioanal. Letters, 7, 269 (1971).

218) S. J. Naqvi : Nucleus, 8, 76(1971) ; Chem. Abstr., 75, 146793 (1971).

219) S. J. Naqvi, D. Huys, L. H. Baetslé : J. Inorg. Nucl. Chem., 33, 4317 (1971).

220) G. H. Nancollas, V. Pekárek : ibid., 27, 1409 (1965).

221) D. Naumann : Kernenergie, 6, 173 (1963) ; Chem. Abstr., 62, 6101 (1965).

222) F. Nelson, D. C. Michelson, H. O. Phillips, K. A. Kraus : J. Chromatogr., 20, 107 (1965).

223) Netherlands Patent Application 6, 412,980 (1965) ; Chem. Abstr., 66, 7411 (1967).

224) Netherlands Patent Application 6,603,607 (1966).

225) R. L. Newacheck, L. J. Beaufait, Jr., E. E. Anderson: Nucleonics, 15, (5), 122 (1957).

226）野村 実，阿部光雄，伊藤卓獮：日化， 1972, 529.

227) 野村 実, 阿部光雄, 伊藤卓䒽 : 電気通信大学学 報，30，91 (1971)。

228) G. Oldham, A. R. Ware, D. J. Sykes : Talanta, 16, 430 (1969).

229) R. Ooms, P. Schonken, W. D'olieslager, L. Baetslé, M. D'hont : J. Inorg. Nucl. Chem., 36, 665 (1974).

230) N.O.Osipova, E.S. Boichinova : Zh.Prikl. Khim. (Leningrad), 41, 2186 (1968).

231) O. Osterried : Z. Anal. Chem., 199, 260 (1964).

232) J. M. Peixoto-Cabeal : J. Chromatogr., 4, 86 (1960).

233) V. Pekárek, M. Benešová : J. Inorg. Nucl. Chem., 26, 1734 (1964).

234) V. Pekárek, S. Maryška : Collection Czech. Chem. Commun., 33, 1612 (1968).

235) V. Pekárek, V. Veselý : J. Inorg. Nucl. Chem., 27, 1151 (1965).

236) V. Pekárek, V. Veselý : Proe. Nucl. Fuel Reprocessing Comecon Confr. Karlovy Vary, p. 165 (1968).

237) V. Pekárek, V. Veselý, J. Ullrich : Bull. Soc. Chim. France, 1968, 1844.

238) V. A. Perevozova, E. S. Boichinova: Zh. Prikl. Khim. (Leningrad), 40, 2679(1967); Chem. Abstr., 68, 72668 (1968).

239) H. O. Phillips, K. A. Kraus : ORNL, 2983, p. 50 (1960).

240) H. O. Phillips, K. A. Kraus : J. Am. Chem. Soc., 84, 2267 (1962).

241) J. Piret, J. Henry, G. Balon, C. Beaudet : Bull. Soc. Chim. France, 1965, 3590.

242) Gr. Popa, Gh. Baiulescu, S. Moldoveanu : Rev. Chim. (Bucharest), 17, 103(1966) ; Chem. Abstr., 64, 19027 (1966).

243) J.Prospert : Comm. Energic. At. (France) Rappt. CEA-R2835, p. 62 (1966) ; Chem. Abstr., 65, 4695 (1966).

244) J. Prospert, J. Lefevre, A. Raggenbass : Comm. 
Eur. Energ. Atom. -EURATOM, EUR-4075, p. 24 (1968) ; Chem. Abstr., 70, 120368 (1969).

245) W.E.Prout, E. R. Russel, H. J. Groh : J. Inorg. Nucl. Chem., 27, 473 (1965).

246) W. E. Prout, E. R. Russel, H. J. Groh : U.S. Patent 3, 296, 123 (1967) ; Chem. Abstr, 66, 51532 (1967).

247) M. Qureshi, I. Akhtar, K. N. Mathur : Anal. Chem., 39, 1766 (1967).

248) M. Qureshi, J.P.Gupta : J. Chem. Soc., A, 1969, 1755.

249) M. Qureshi, J. P. Gupta : ibid., 1970, 2620.

250) M. Qureshi, J. P. Gupta : J. Chromatogr., 62, 439 (1971).

251) M. Qureshi, J. P. Gupta : V. Sharma : Anal. Chem., 45, 1901 (1973).

252) M. Qureshi, K. Husain, J. P. Gupta : J.Chem. Soc., A, 1971, 29.

253) M. Qureshi, W. Husain : Separ. Sci., 4, 197 (1969).

254) M. Qureshi, W. Husain : J. Chem. Soc., A, 1970, 1204.

255) M. Qureshi, A. H. Israili : Anal. Chim. Acta, 41, 523 (1968)

256) M. Qureshi, R.Kumar, H.S.Rathore : J. Chem. Soc., $A$, 1970, 272.

257) M. Qureshi, R. Kumar, H. S. Rathore : Anal. Chem., 44, 1081 (1972).

258) M. Qureshi, R.Kumar, H.S.Rathore : Talanta, 19, 1377 (1972).

259) M. Qureshi, V. Kumar, J. Chem. Soc., A, 1970, 1488.

260) M. Qureshi, V. Kumar : J. Chromatogr., 62, 431 (1971).

261) M. Qureshi, V. Kumar : N. Zehra : ibid., 67, 351 (1972)

262) M. Qureshi, K. N. Mathur, A. H. Israili : Talanta, 16, 503 (1969).

263) M. Qureshi, S. A. Nabi : J. Inorg. Nucl. Chem., 32, 2059 (1970).

264) M. Qureshi, S. A. Nabi : Talanta, 19, 1033 (1972).

265) M. Qureshi, S. Z. Qureshi : J. Chromatogr., 22, 198 (1966)

266) M. Qureshi, H. S. Rathore : J. Chem. Soc., A, 1969, 2515.

267) M. Qureshi, H. S. Rathore, R. Kumar : ibid., 1970, 1986

268) M. Qureshi, H. S. Rathore, R. Kumar : J. Chromatogr., 54, 269 (1971).

269) M. Qureshi, J. P. Rawat: J. Inorg. Nucl. Chem., 30, 305 (1968).

270) M. Qureshi, J. P. Rawat : Sepn. Sci., 7, 297 (1972).

271) M. Qureshi, J. P. Rawat, V. Sharma : Talanta, 20, 267 (1973).

272) M. Qureshi, K. G. Varshney, J. Inorg. Nucl. Chem., 30, 3081 (1968).

273) M. Qureshi, K. G. Varshney, S. K. Kabiruddin : Can. J. Chem., 50, 2071 (1972).

274) M. Qureshi, K. G. Varshney, F. Khan : J. Chromatogr., 65, 547 (1972).

275) M.Qureshi, M. N. Zehra, S. A. Nabi : Talanta,
20, 609 (1973).

276) M. K. Rahman, A. M. S. Haq : J. Chromatogr., 53, 613 (1970).

277) M. K. Rahman, A. M. S. Haq, F.B.A.Maroof: ibid., 67, 389 (1972).

278) J. Rais, V. Kouřím : Czech. Patent 117, 268 (1966).

279) M.Ramaswamy, M.Rajan, N.S.Sunder : India At. Energy Comm., Bhabha, At. Res. Centre, BARC-497, p. 23 (1970) ; Chem. Abstr., 75, 43629 (1971)

280) R. L. Rebrtus : Anal. Chem., 38, 1089 (1966).

281) W. Rehak, B. Feddersen : Anal. Abstr., 20, 4371 (1971).

282) P. Rémy, A. Boullé : Bull. Soc. Chim. France, 1968, 1838.

283) H. J. Riedel : Nukleonite, 5, 48 (1963); Chem. Abstr., 58, 11983 (1963).

284) R. Ripan, A. Suteu : Rev. Roum. Chim., 12, 1339 (1967).

285) R. Ripan, A. Suteu : ibid., 13, 179 (1968).

286) G. G. Rocco, J. R. Weiner, J. P. Cali : U. S. Dept.Com., Office Tech.Serv. AD611024(1964); Chem. Abstr., 64, 5788 (1966).

287) I. Roelandts : Radiochem. Radioanal. Letters, 12, 89 (1972).

288) S.Z. Roginskii, O.V.Altshulet, M.I. Yanovskii, E. I. Malinina, A. E. Morokhovets : Radiokhimiya, 2, 43, 438 (1960).

289) S. D. Roy, M. S. Das : Anal. Chim. Acta, 51, 509 (1970).

290) A. Ruvarac, V. D. Marijanac : J. Chromatogr., 76, 221 (1973).

291) A. Ruvarac, V. Veselý : J. Inorg. Nucl. Chem., 32, 3939 (1970).

292) V. I. Savel'eva, E. B. Khlobystina : Tr. Mosk. Khim-Tekhnol. List, No. 43, 89 (1963) ; Chem. Abstr., 62, 12423 (1965).

293) J. Scheidhauer, G. Vergnaud, A. Flamant : Commis. Energ. At. France, Rap., No. CEAR-3585, p. 9 (1968) ; Chem. Abstr., 70, 83317 (1969).

294) A. I. Shafiev, Yu. V. Efremov : Radiokhimiya, 14, 771 (1972) ; Chem. Abstr., 78, 92067(1973).

295) L. M. Sharygin, A. A. Pospelov, V. G. Chuklantsev : Radiokhimiya, 7, 744 (1965) ; Chem. Abstr., 64, 11905 (1966).

296) V. A. Shichko, E. S. Boichinova : Zh. Prik. Khim., 41, 526 (1968).

297) E. A. Shul'ga, V. V. Vol'kin, S. A. Kolesova : Izv. Vyssh. Ucheb. Zaved., Tsvet : Met., 16, 109 (1973) ; Chem. Abstr., 79, 118670 (1973).

298) Yu. D. Sinochkin, D. A. Perumov : Soosazhdenie $i$ Adsorbtsiya Radioaktivn. Elementov, Akad. Nauk SSSR, Otd. Obshch. i Tekhn. Khim., 140 (1965); Chem. Abstr., 63, 9419 (1965).

299) J. van R. Smit : Nature (London), 181, 1530 (1958).

300) J. van R. Smit : J. Inorg. Nucl. Chem., 27, 227 (1965).

301) J. van R. Smit : Ger. Patent 1, 210, 416 (1966); Chem. Abstr., 64, 18854 (1966).

302) J. van R.Smit : J. J. Jacobs, W.Robb : J Inorg. 
Nucl. Chem., 12, 95 (1959).

303) J. van R. Smit, W. Robb : ibid., 26, 509 (1964).

304) J. van R. Smit, W. Robb, J. J. Jacobs : ibid., 12, 104 (1959).

305) J. van R. Smit, W. Robb, J. J. Jacobs : Nucleonics, No. 9, 116 (1959).

306) R.W.Stoughton : U.S.Patent 2, 970, 035(1961).

307) L.Szirtes, L.Zsinka : Chem.Zvesti, 21, 620(1967).

308) L. Szirtes, L. Zsinka : Radiochem. Radioanal. Letters, 7, 61 (1971).

309) L. Szirtes, L. Zsinka, K. B. Zaborenko, B. Z. Iofa : Acta Chim.Acad.Sci.Hung., 54, 215 (1967).

310) Ton-Pol Tam, Pu. Sun, Kwok-Yuen Chan : Hua Hsueh, 9, 219 (1972) ; Chem. Abstr., 69, 61782 (1968).

311) I. V. Tananaev, A.P.Korolkov : Izv. Akad. Nauk SSSR, Neorgan. Mater., 1, 100 (1965).

312) I. V. Tananaev, A. P. Korolkov : ibid., 1, 607 (1965).

313) I. V. Tananaev, A. P. Korolkov : ibid., 1, 1577 (1965).

314) S. N. Tandn, J.S.Gill : Talanta, 20, 585 (1973).

315) K. Terada, H. Hayakawa, K. Sawada, T.Kiba: ibid., 17, 955 (1970).

316) V. F. Tikavji, V. D. Komarov : Izv. Akad. Nauk SSSR, Neorgan. Mater., 5, 180 (1969).

317) V. F. Tikavji, V. S. Soldatov, G.L. Starobinets, V. A. Labetskii : USSR patent 167, 826 (1965).

318) V. F. Tikavji, A. S. Zhukova : Geterogennye Reaktsii i Reakts. Sposobnost (Minsk, Vyssh. Skola Sb., 71 (1964).

319) E. Torracca, U. Costantino, M. A. Massucci : J. Chromatogr., 30, 584 (1967).

320) S. Vaidyanathan, L. H. Baetslé : Radiochem. Radioanal. Letters, 5, 247 (1970).

321) V. Veselý, V. Pekárek : J. Inorg. Nucl. Chem., 25, 697 (1963).

322) V. Veselý, V. Pekárek : ibid., 27, 1419 (1965).

323) V. Veselý, V. Pekárek, M. Abbrent : ibid., 27, 1159 (1965).

324) V. Veselý, V. Pekárek, A. Ruvarac : Bull. Soc. Chim. France, 1968, 1832.

325) V. Veselý, V. Pekárek, Z. Urbanec : 5th Radio- chem. Confr,, Zrikov-Castle, Czech., (1969).

326) V. Veselý, A. Ruvarac, L. Sedláková : J. Inorg. Nucl. Chem., 30, 1101 (1968).

327) I. K. Vinter, E. S. Boichinova, N. E. Denisova, R. B. Chetverina : Zh. Prikl. Khim., 46, 1117, 1471 (1973).

328) D. Vissers : Ph. D. Thesis, Univ. Wisconsin, Madison, (1959).

329) V. V. Volkhin, S. A. Kolesova : Zh. Prikl. Khim. (Leningrad), 40, 342 (1967).

330) V. V. Volkhin, S. A. Kolesova, A. F. Kalashnikova; Redk. Shchelochnye Elem., Sb. Dokl. Vses. Soveshch., 2nd, Novosobirsk, p. 174 (1964).

331) V. V. Volkhin, E. A. Kosheeva : Izv.Akad. Nauk SSSR, Neorgan. Mater., 1, 1.577 (1965).

332) M. Wald, W. Soyka, B. Kaysser : Talanta, 20, 405 (1973).

333) R. I. Walker, W. H. Shipman : J. Chromatogr., 50, 157 (1970).

334) K. Watari, K. Imai, M. Izawa : J. Nucl. Sci. Technol. (Tokyo), 4, 190 (1967) ; Chem. Abstr., 67, 49408 (1967).

335) K. Watari, K. Imai, M. Izawa : ibid., 5, 309 (1968) ; Chem. Abstr., 69, 48558 (1968).

336) C. J. Wiedenheft : J.Inorg.Nucl.Chem., 31, 1859 (1969).

337) A. Winkler, E. Thilo : Z. Anorg. Allg. Chem., 346, 92 (1966).

338) Pe-Hai Yin : Hua Hsueh Hsueh Pao, 31, 260 (1965) ; Chem. Abstr., 63, 15527 (1965).

339) Pe-Hai Yin, Yung-Hsiang Chu : ibid., 32, 103 (1966) ; Chem. Abstr., 65, 11321 (1966).

340) K. B. Zaborénko, L. Szirtes, L. Zsinka : Vestn. Mosk. Univ. Khim., 23, 59 (1968).

341) L. Zsinka, L. Szirtes : Magy. Kem. Lapja, 21, 536 (1966) ; Chem. Abstr., 66, 81335 (1967).

342) L. Zsinka, L. Szirtes : Radiochem. Radioanal. Letters, 2, 257 (1969).

343) L.Zsinka, L.Szirtes : Proc 2nd Hungarian Conf. Ion-Exchange, Balatonszeplak, 2, p. 627 (1969).

344) L. Zsinka, L. Szirtes, V. Stenenger : Radiochem. Radioanal. Letters, 4, 257 (1970). 